\title{
Observatório de Direito Público
}

\section{Casoteca da América Latina}

O PRojeto CASOtECA dA AMÉRICA LATINA é um trabalho do grupo de pesquisa CORTES Constitucionais E DEMOCRACIA ${ }^{1}$, vinculado ao Programa de Mestrado e Doutorado do Centro Universitário de Brasília - UniCEUB. O grupo reúne alunos da graduação, da pós-graduação lato sensu, mestrandos e doutorandos e tem por objeto o estudo da relação de tensão entre a jurisdição constitucional e a democracia. Essa relação de tensão pode ser sintetizada na seguinte pergunta: Em que medida as cortes constitucionais e supremas cortes, compostas por juízes não eleitos pelo voto popular, podem interferir sobre as escolhas efetuadas pelos representantes do povo, que integram os Poderes Legislativo e Executivo e formulam políticas públicas?

A partir do segundo semestre de 2016, o grupo direcionou a sua pesquisa para a implementação de direitos sociais por cortes constitucionais e supremas cortes de países da América Latina. De modo geral, a implementação de direitos sociais ocorre em uma realidade marcada por: recursos substancialmente limitados e demandas que tendem ao infinito. As decisões sobre quais sujeitos e que direitos serão atendidos impõem escolhas alocativas, que, alega-se, devem ser efetuadas no âmbito da política majoritária, por representantes legitimados pelo voto popular. Na prática, contudo, as cortes, no Brasil, têm interferido substancialmente sobre tais escolhas e se tornaram um agente relevantíssimo da implementação de direitos sociais. O presente trabalho foi motivado pelo desejo de conhecer como outros países da América Latina lidam com a judicialização desses direitos e como tratam a relação de tensão entre constitucionalismo e democracia.

Optamos por começar nossa pesquisa pelo estudo da implementação de direitos sociais pelas cortes constitucionais e/ou supremas cortes da Colômbia, da Costa Rica, do Chile, da Argentina, do Equador e do Peru. E decidimos montar uma biblioteca de casos com os julgados que nos chamaram mais atenção, consolidados em relatórios padronizados. Não tratamos a diferenciação entre direitos de primeira e de segunda geração com rigor. Logo no princípio do trabalho ficou claro que essa classificação era pouco produtiva e que, em muitos casos, direitos de liberdade se imbricavam com direitos prestacionais. Por isso, quando havia dúvida sobre o enquadramento de um determinado direito como social, desde que houvesse alguma relação com deveres prestacionais do Estado, optávamos por mantê-lo na casoteca.

Ao longo da pesquisa, o grupo contou com o apoio de centros de excelência vinculados ao Programa de Pós-graduação do UniCEUB, dentre os quais elencamos o Centro Brasileiro de Estudos Constitucionais - CBEC e o Instituto de Diálogos Constitucionais - IDCon. Ambos os institutos organizaram palestras e debates com protagonistas do constitucionalismo latino-americano, como

${ }^{1}$ Disponível em: <dgp.cnpq.br/dgp/espelhogrupo/7629538930156064>. Diretório dos Grupos de Pesquisa no Brasil, Plataforma Lattes.

Revista Publicum

Rio de Janeiro, v. 3, n. 2, 2017, p. 286-338

http://www.e-publicacoes.uerj.br/index.php/publicum

DOI: 10.12957/publicum.2017.31883 
Roberto Gargarella, Ricardo Luis Lorenzetti e Carlos Bernal Pulido. Esses eventos motivaram nossa pesquisa e inspiraram os nossos alunos. Agradecemos, ainda, às coordenações, aos professores, alunos e funcionários do Programa de Mestrado e Doutorado e da Pós-Graduação Lato Sensu da UniCEUB pelo apoio ao projeto.

Com esses esclarecimentos, apresentamos, nesta primeira publicação, as CASOTECAS DA COLÔMBIA E DO EQUADOR. Como o leitor poderá conferir nas próximas páginas, esses vizinhos, tão próximos e ainda tão desconhecidos, reúnem cortes constitucionais bastante atuantes e casos de implementação de direitos sociais de uma riqueza ímpar, com diversos pontos em comum com a prática brasileira.

Brasília, 12 de dezembro de 2017.

\section{Patrícia Perrone Campos Mello Coordenadora}

Alessia Barroso L. Campos

Chevitarese

Coordenadora

Felipe Meneses Graça

Pesquisador Associado 


\section{Casoteca da Colômbia²}

\section{Coordenação Geral}

Patrícia Perrone Campos Mello ${ }^{3}$

Alessia Barroso Lima Brito Champos Chevitarese 4

\section{Coordenação do Grupo}

Ana Borges Coelho Santos ${ }^{5}$

\section{Pesquisadores}

Alessia Chevitarese

Ana Borges Coelho Santos

Camila Nascimento de Souza ${ }^{6}$

Felipe Meneses Graça ${ }^{7}$

Patrícia Perrone Campos Mello

\section{Pesquisador Revisor}

Felipe Meneses Graça

\section{Membro Executivo}

Naiara Ferreira Martins ${ }^{8}$

\footnotetext{
${ }^{2}$ O presente trabalho foi produzido pelo grupo de pesquisa CORTES CONSTITUCIONAIS E DEMOCRACIA, vinculado ao Programa de Mestrado e Doutorado do Centro Universitário de Brasília - UNICEUB. Coordenadoras: Patrícia Perrone Campos Mello e Alessia Barroso Lima Brito Campos Chevitarese. Informações disponíveis em: $<$ https://www.uniceub.br/cursos/direito-e-relacoes-internacionais/mestrado-e-doutorado/direito/gruposde-pesquisa.aspx\#c>.

3 Professora do Programa de Mestrado e Doutorado e da Graduação do Centro Universitário de Brasília UNICEUB. Doutora e Mestre em Direito Público (UERJ). Assessora de Ministro do Supremo Tribunal Federal. Procuradora do Estado do Rio de Janeiro.

4 Professora da Pós-Graduação (lato sensu) e da Graduação do Centro Universitário de Brasília - UNICEUB. Professora da Clínica de Direitos Humanos do UNICEUB. Doutora e Mestre pelo Centro Universitário de Brasília - UNICEUB. Membro da Comissão de Assuntos Constitucionais da OAB/DF.

5 Subprocuradora-Geral da República, mestranda e especialista em Direitos Sociais, Ambiental e do Consumidor pelo UNICEUB.

${ }^{6}$ Graduanda em Direito pelo Centro Universitário de Brasília - UNICEUB. Pesquisadora associada ao Centro Brasileiro de Estudos Constitucionais - CBEC (Universitário) - UNICEUB. Participante discente da Clínica de Formação Jurídica e Educação Política UNICEUB.

7 Graduando em Direito pelo Centro Universitário de Brasília - UNICEUB. Pesquisador associado ao Centro Brasileiro de Estudos Constitucionais - CBEC (Universitário) - UNICEUB. Pesquisador associado ao Instituto de Diálogos Constitucionais - IDCon. Participante discente da Clínica de Direitos Humanos do UNICEUB.

8 Bacharel em Direito pelo Centro Universitário de Brasília - UNICEUB e graduada em Letras - Língua e Literatura Japonesa pela Universidade de Brasília - UnB.
} 


\begin{tabular}{|c|c|}
\hline 1. CASO & $\begin{array}{l}\text { ESTADO DE COISAS INCONSTITUCIONAL: DESLOCAMENTO FORÇADO (VIOLAÇÃO } \\
\text { ESTRUTURAL DE DIVERSOS DIREITOS SOCIAIS) }\end{array}$ \\
\hline CLASSE E NÚMERO & $\mathrm{T}-025 / 04^{9}$ \\
\hline ÓRGÃO JULGADOR & Colômbia, Corte Constitucional da Colômbia, Terceira Sala de Revisão. \\
\hline RELATOR & Manuel José Cepeda Espinosa \\
\hline REQUERENTES & $\begin{array}{l}\text { Fundação Ayudémonos FUNDYUDE (processo T-653010). Ao processo T- } \\
653010 \text {, foram reunidos outros } 108 \text { processos, em que constam, como } \\
\text { requerentes, uma associação humanitária(T-680268), associações de } \\
\text { deslocados (T-680627, T-681839,T-686154, T-688767, T-695161, T-700902), } \\
\text { procuradores municipais (personeros municipales) (T-675083 e T-692880) e } \\
\text { pessoas físicas (demais processos). O conjunto de ações reúne pleitos de um } \\
\text { total de } 1150 \text { núcleos familiares, compostos, em média, por } 4 \text { pessoas por } \\
\text { núcleo, todos pertencentes à população deslocada. Parte substancial dos } \\
\text { grupos é composta principalmente por mulheres, na condição de cabeça de } \\
\text { família, além de pessoas de terceira idade, menores e indígenas. A última } \\
\text { reunião de processos ocorreu em } 10 \text { de novembro de 2003, com o } \\
\text { apensamento do processo T-775898. }\end{array}$ \\
\hline REQUERIDOS & $\begin{array}{l}\text { Red de Solidaridad Social, Departamento Administrativo da Presidência da } \\
\text { República, Ministério da Fazenda e Crédito Público, Ministério da Saúde e do } \\
\text { Trabalho e Seguridade Social (depois Ministério da Proteção Social), Ministério } \\
\text { da Agricultura, Ministério da Educação, Instituto Colombiano de Moradia de } \\
\text { Interesse Social e Reforma Urbana (INURBE), Instituto Colombiano para a } \\
\text { Reforma Agrária (INCORA), Serviço Nacional de Aprendizagem (SENA) e várias } \\
\text { administrações municipais e departamentais. }\end{array}$ \\
\hline DATA DE JULGAMENTO & 22 de janeiro de 2004 \\
\hline DATA DE PUBLICAÇÃo & Data de publicação não informada. \\
\hline FATOS & $\begin{array}{l}\text { Associações, procuradores municipaise cidadãos ajuizaram ações de tutela em } \\
\text { razão de problemas no conteúdo e alcance da política estatal de atendimento } \\
\text { às vítimas do deslocamento forçado. Os principais problemas apontados } \\
\text { foram: (i) a grave situação de vulnerabilidade que atinge a população } \\
\text { deslocada; (ii) o longo tempo decorrido sem que tenham obtido os } \\
\text { auxíliosprevistos na política para atenção à população deslocada; (iii) o alto } \\
\text { volume de ações detutela propostaspelos deslocados, e o fato de quea } \\
\text { propositura de taisaçõester se convertido, na prática, em uma pré-condição } \\
\text { para obtenção da ajuda solicitada; (iv) o caráter reiterado e persistente dos } \\
\text { problemas narrados. }\end{array}$ \\
\hline $\begin{array}{l}\text { FUNDAMENTOS JURÍDICOS } \\
\text { DO PEDIDO }\end{array}$ & $\begin{array}{l}\text { Em razão da multiplicidade de direitos constitucionais afetados pelo } \\
\text { deslocamento forçado e diante das circunstâncias de especial debilidade, } \\
\text { vulnerabilidade e ausência de mecanismos de defesa, em que se encontram os } \\
\text { deslocados, têm eles o direito de receber, com urgência, um tratamento } \\
\text { diferenciado por parte do Estado, consistente no pronto atendimento de suas } \\
\text { necessidades. A Lei } 387 \text { de } 1997^{10} \text { reconheceu que a atenção à população } \\
\text { deslocada é urgente e prioritária. }\end{array}$ \\
\hline PEDIDO & $\begin{array}{l}\text { Os requerentes buscam o atendimento de um ou de vários dos seguintes } \\
\text { pedidos, dentre outros: (i) reconhecimento como deslocados, com os }\end{array}$ \\
\hline
\end{tabular}

9 COLÔMBIA. Corte Constitucional da Colômbia. T-025/04. Terceira Sala de Revisão. Autor: Fundação Ayudémonos FUNDYUDE e outros. Réu: Red de Solidaridad Social e outros. Relator(a): Manuel José Cepeda Espinosa. Bogotá, 22 de janeiro de 2004. Disponível em:

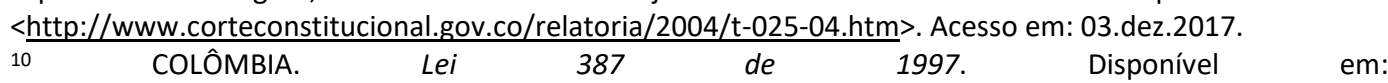
<http://www.alcaldiabogota.gov.co/sisjur/normas/Norma1.jsp?i=340>. Acesso em: 14.mai.2017. 


\begin{tabular}{|c|c|}
\hline & $\begin{array}{l}\text { benefícios decorrentes desta condição; (ii) ajuda humanitária de emergência; } \\
\text { (iii) adoção de um programa de segurança alimentar; (iv) fornecimento de } \\
\text { medicamentos; (v) acesso dos filhos à educação; (vi) capacitação; (vii) suporte } \\
\text { do poder público para desenvolver os programas de moradia e projetos } \\
\text { produtivos; (viii) aporte de recursos para a população deslocada e seus } \\
\text { programas; (ix) solução efetiva, em prazo certo e determinado, de suas } \\
\text { postulações; (x) advertência ao representante da rede de solidariedade sobre } \\
\text { sua responsabilidade em caso de omissão; (xi) adequação do comitê municipal } \\
\text { para atenção integral ao deslocado. }\end{array}$ \\
\hline $\begin{array}{l}\text { EMENTA OU TRECHO } \\
\text { DESTACADO }\end{array}$ & $\begin{array}{l}\text { "A Terceira Sala de Revisão, ao resolver sobre as presentes ações de tutela, } \\
\text { resolve, pelas condições de vulnerabilidade extrema nas quais se encontra a } \\
\text { população deslocada, assim como pela omissão reiterada, por parte das } \\
\text { distintas autoridades encarregadas de sua atenção, conferir-lhe uma proteção } \\
\text { oportuna e efetiva. Consideram-se violados, quer no que respeita aos } \\
\text { postulantes do presente processo, quer no que respeita à população deslocada } \\
\text { em geral, seus direitos a uma vida digna, à integridade pessoal, à igualdade, de } \\
\text { petição, ao trabalho, à saúde, à seguridade social, à educação, ao mínimo vital, } \\
\text { à proteção especial devida às pessoas de terceira idade, à mulher cabeça de } \\
\text { família e às crianças (...). Esta violação tem ocorrido de maneira massiva, } \\
\text { prolongada e reiterada e não é imputável a uma única autoridade, mas } \\
\text { obedece a um problema estrutural, que afeta a toda a política de atenção } \\
\text { desenhada pelo Estado, e a seus distintos componentes, em razão da } \\
\text { insuficiência de recursos destinados a financiar dita política e da precária } \\
\text { capacidade institucional de implementá-la (...). Tal situação constitui um } \\
\text { estado de coisas inconstitucional que será declarado formalmente nesta } \\
\text { decisão" (tradução livre). }\end{array}$ \\
\hline DECISÃO FINAL & $\begin{array}{l}\text { A Corte fundamenta sua decisão: (i)na Carta de Princípios do Deslocamento } \\
\text { Interno, da Organização das Nações Unidas (ONU); }{ }^{11} \text { (ii) no regime jurídico } \\
\text { prioritário a que fazem jus as vítimas do deslocamento forçado, instituído pela } \\
\text { Lei } 387 \text {, de } 1997 ;^{12} \text { e, por fim, (iii) nas seguintes normas da Constituição da } \\
\left.\text { Colômbia: as finalidades essenciais do Estado (art. } 2^{\circ}\right)^{13} \text { : o direito fundamental }\end{array}$ \\
\hline
\end{tabular}

11 ORGANIZAÇÃO DAS NAÇÕES UNIDAS (ONU). Escritório de Coordenação de Assuntos Humanitários (OCHA). Princípios Orientadores relativos aos Deslocados Internos. Disponível em: <http://www.ohchr.org/Documents/Issues/IDPersons/GPPortuguese.pdf>. Acesso em: 02.dez.2017.
12 COLÔMBIA
Lei
387
de 1997.
Disponível
em:

<http://www.alcaldiabogota.gov.co/sisjur/normas/Norma1.jsp?i=340>. Acesso em: 14.mai.2017.

13 COLÔMBIA. Constituição Política da Colômbia, de 1991. "Artigo 2‥ Os propósitos essenciais do Estado são: servir a comunidade, promover a prosperidade geral e garantir a eficácia dos princípios, direitos e deveres consagrados na Constituição; facilitar a participação de todos nas decisões que os afetam e em questões econômicas, políticas, administrativas e culturais da Nação; defender a independência nacional, manter a integridade territorial e garantir a coexistência pacífica e a validade de uma ordem justa. As autoridades da República são instituídas para proteger todas as pessoas residentes na Colômbia, em sua vida, honra, bens, crenças e outros direitos e liberdades, e para garantir o cumprimento das obrigações sociais do Estado e dos indivíduos" (livre tradução). Disponível $<$ http://www.corteconstitucional.gov.co/inicio/Constitucion\%20politica\%20de\%20Colombia.pdf>. Acesso em: 1‥dez.2017. 


\begin{tabular}{|l|l|}
\hline & $\begin{array}{l}\text { à igualdade (art. 13) } \\
\text { previsão dos gastos públicos sociais (art. 350) }{ }^{16} \text { e a finalidade social dos } \\
\text { serviços públicos (art. 366) }{ }^{17} \text {. Ao final, defere direitos, reforma e confirma } \\
\text { decisões de outras instâncias e determina providências para o atendimento } \\
\text { dos direitos dos requerentes. }\end{array}$ \\
\hline VOTO VENCIDO & Não houve. Decisão unânime. \\
\hline $\begin{array}{l}\text { PORQUE o CASO É } \\
\text { PARADIGMÁtıCo }\end{array}$ & $\begin{array}{l}\text { Trata-se do caso mais bem sucedido de declaração do ECl pela Corte. Isso se } \\
\text { deve não só ao fato de se ter enfrentadoa violação massiva de direitos } \\
\text { fundamentais e determinado "remédios estruturais", como é de praxe da } \\
\text { declaração de ECI, mas ao fato de a Corte ter criado um sistema complexo de } \\
\text { monitoramento das ordens proferidas, para garantir a efetividade da } \\
\text { decisão }\end{array}$ \\
\hline LINK:<http://www.corteconstitucional.gov.co/relatoria/2004/t\%2D025\%2D04.htm>. \\
\hline PALAVRAS-CHAVE & $\begin{array}{l}\text { ESTADO DE COISAS INCONSTITUCIONAIS - DESLOCAMENTO FORÇADO - } \\
\text { PROBLEMA ESTRUTURAL. }\end{array}$ \\
\hline
\end{tabular}

${ }^{14}$ COLÔMBIA. Constituição Política da Colômbia, de 1991. “Artigo 13. Todas as pessoas nascem livres e iguais perante a lei, receberão a mesma proteção e tratamento das autoridades e gozarão dos mesmos direitos, liberdades e oportunidades em nenhuma discriminação por razões de sexo, raça, origem nacional ou familiar, língua, religião, opinião política ou filosófica. O Estado promoverá as condições para que a igualdade seja real e efetiva e adotará medidas em favor de grupos discriminados ou marginalizados. O Estado protegerá especialmente aquelas pessoas que por sua condição econômica, física ou mental se encontrem em circunstância de debilidade manifesta e sancionará os abusos ou maus tratos que contra elas se cometam" (livre tradução). Disponível em: <http://www.corteconstitucional.gov.co/inicio/Constitucion\%20politica\%20de\%20Colombia.pdf>. Acesso em: 19.dez.2017.

${ }^{15}$ COLÔMBIA. Constituição Política da Colômbia, de 1991. "Artigo 209. A função administrativa está a serviço de interesses gerais e é desenvolvida com base nos princípios de igualdade, moralidade, eficácia, economia, velocidade, imparcialidade e publicidade, através da descentralização, delegação e desconcentração de funções. As autoridades administrativas devem coordenar suas ações em conformidade com os propósitos do Estado. A administração pública, em todas as suas ordens, terá um controle interno que será exercido nos termos dispostos em lei" (livre tradução). Disponível em: $<$ http://www.corteconstitucional.gov.co/inicio/Constitucion\%20politica\%20de\%20Colombia.pdf>. Acesso em: 1‥dez.2017.

16 COLÔMBIA. Constituição Política da Colômbia, de 1991. "Artigo 350. A lei de dotações deve ter um componente chamado despesa social pública que agrupará os itens de tal natureza, de acordo com a definição feita pela respectiva lei orgânica. Exceto nos casos de guerra estrangeira ou por razões de segurança nacional, as despesas públicas sociais terão prioridade sobre qualquer outra. Na distribuição territorial da despesa pública social, será levado em consideração o número de pessoas com necessidades básicas insatisfeitas, população e eficiência fiscal e administrativa, de acordo com os regulamentos que a lei estabelecerá. 0 orçamento de investimento não pode ser reduzido em termos percentuais com relação ao ano anterior em relação à despesa total da respectiva lei de dotações" (livre tradução). Disponível em: $<$ http://www.corteconstitucional.gov.co/inicio/Constitucion\%20politica\%20de\%20Colombia.pdf >. Acesso em: 1‥dez.2017.

17 COLÔMBIA. Constituição Política da Colômbia, de 1991. “Artigo 366. O bem-estar geral e o melhoramento da qualidade de vida da população são finalidades sociais do Estado. Será objetivo fundamental de sua atividade a solução das necessidades insatisfeitas de saúde, de educação, de saneamento ambiental e de água potável. Para tais efeitos, nos programas e orçamentos da Nação e das entidades territoriais, o gasto público social terá prioridade sobre qualquer outra alocação" (livre tradução). Disponível em: $<$ http://www.corteconstitucional.gov.co/inicio/Constitucion\%20politica\%20de\%20Colombia.pdf>. Acesso em: 1‥dez.2017.

${ }^{18}$ ESPINOSA, Manuel José Cepeda; LANDAU, David. Colombian Constitutional Law: leading cases. New York: Oxford University Press, 2017. p. 186-187; CAMPOS, Carlos Alexandre de Azevedo.Estado de Coisas Inconstitucional. Salvador: JusPodivm, 2016. p. 142-143.

Revista Publicum

Rio de Janeiro, v. 3, n. 2, 2017, p. 286-338

http://www.e-publicacoes.uerj.br/index.php/publicum

DOI: $10.12957 /$ publicum.2017.31883 


\begin{tabular}{|c|c|}
\hline 2.CASO & $\begin{array}{l}\text { ESTADO DE COISAS INCONSTITUCIONAL: SISTEMA PENITENCIÁRIO } \\
\text { (VIOLAÇÃO ESTRUTURAL DE DIVERSOS DIREITOS SOCIAIS) }\end{array}$ \\
\hline CLASSE E NÚMERO & $\mathrm{T}-762 / 15^{19}$ \\
\hline ÓRGÃO JULGADOR & Colômbia, Corte Constitucional da Colômbia, Quinta Sala de Revisão. \\
\hline RELATOR & Gloria Stella Ortiz Delgado \\
\hline REQUERENTES & $\begin{array}{l}\text { Ao processo T-3927909 foram apensados o processo T-3978802 e, } \\
\text { posteriormente, mais } 16 \text { processos, nos quais constam como requerentes: } \\
\text { defensores do povo em nível regional (T-4043750 e T-4051730), procuradores } \\
\text { municipais (personeros municipales) (T-4063994 e T-4076529) e pessoas } \\
\text { físicas. }\end{array}$ \\
\hline REQUERIDOS & $\begin{array}{l}\text { Diversos estabelecimentos penitenciários, Defensoria do Povo, Procuradoria } \\
\text { Geral da Nação, Conselho Superior da Judicatura, Agencia Nacional de Defesa } \\
\text { do Estado, Ministério da Fazenda e Crédito Público, Ministério da Saúde e } \\
\text { Proteção Social, Ministério da Justiça e do Direito, Departamento Nacional de } \\
\text { Planejamento, Controladoria Geral da República, Instituto de Medicina Legal, } \\
\text { Congresso da República, Juizados de Controle de Garantias e de Execução de } \\
\text { Penas, Secretarias de Saúde, Secretarias de Governo, Secretarias de Fazenda, } \\
\text { Instituto Nacional Penitenciário da Colômbia - INPEC, Unidad de Servicios } \\
\text { Penitenciarios y Carcerarios - USPEC, Caja de Previsión Social de } \\
\text { Comunicaciones Entidad Promotora de Salud - CAPRECOM EPS, entre outros. }\end{array}$ \\
\hline DATA DE JULGAMENTO & 16 de dezembro de 2015 \\
\hline DATA DE PUBLICAÇÃO & Data de publicação não informada. \\
\hline FATOS & $\begin{array}{l}\text { O caso representa um conjunto de ações de tutela que apontam problemas } \\
\text { estruturais em relação aos presídios, em razão da superlotação e da má } \\
\text { qualidade dos serviços, que transcendem a dinâmica de cada um dos } \\
\text { estabelecimentos comprometidos e se estendem ao nível nacional, a todo o } \\
\text { sistema carcerário e penitenciário, gerando graves problemas de saúde física } \\
\text { e psicológica aos presos. São representativos dos problemas apresentados: (a) } \\
\text { no processo T-3987203, o relato sobre a existência de apenas uma ducha e de } \\
\text { três banheiros para } 800 \text { presos, o mau cheiro e a proliferação de roedores e } \\
\text { insetos; (b) no processo T-3989532, o relato de que os internos têm que dormir } \\
\text { no chão das celas ao lado dos banheiros; (c) no processo T-3989814, o relato } \\
\text { de falta de acesso à luz solar e a medicamentos; (d) no processo T-4074694, o } \\
\text { relato de que os presos dormem nos corredores, a presença de epidemias, a } \\
\text { péssima alimentação e a falta de intimidade em visitas conjugais; (e) no } \\
\text { processo T-4075719, o relato sobre a existência de problemas de saúde } \\
\text { severos, carência de sanitários e de água potável, bem como a realização dos } \\
\text { banhos em um poço de sistema artesanal; e (f) no processo T-4076801, o relato } \\
\text { sobre a deficiência dos serviços sanitários, escassez de água e de espaço de } \\
\text { mobilidade, além da proliferação de doenças e dos precários serviços de saúde. }\end{array}$ \\
\hline $\begin{array}{l}\text { FUNDAMENTOS JURÍDICOS } \\
\text { DO PEDIDO }\end{array}$ & $\begin{array}{l}\text { Proteção de direitos fundamentais, como o direito (i) à vida em condições de } \\
\text { dignidade; (ii) à saúde; (iii) ao ambiente saudável; (iv) à integridade física; (v) à } \\
\text { igualdade; e (vi) à intimidade. }\end{array}$ \\
\hline PEDIDO & $\begin{array}{l}\text { Os demandantes postularam, no conjunto das ações de tutela: (i) a proibição } \\
\text { de entrada de novos presos nos estabelecimentos superlotados; (ii) visitas aos } \\
\text { estabelecimentos superlotados; (iii) colchonetes, lençóis e kits de higiene; (iv) } \\
\text { o traslado do excedente de detentos para outros estabelecimentos; (v) ordem }\end{array}$ \\
\hline
\end{tabular}

${ }^{19}$ COLÔMBIA. Corte Constitucional da Colômbia. T-762/15. Quinta Sala de Revisão. Autor: Diosemel Quintero Bayona e outros. Réu: EPMSC, Cárcel Modelo de Bucaramanga, PabellónCuarto.e outros. Relator(a): Gloria Stella Ortiz Delgado. Bogotá, 16 de dezembro de 2015. Disponível em: <http://www.corteconstitucional.gov.co/relatoria/2015/t-762-15.htm>. Acesso em: 03.dez.2017. 


\begin{tabular}{|c|c|}
\hline & $\begin{array}{l}\text { judicial visando a serem estabelecidas ações administrativas e contratuais para } \\
\text { atendimento das necessidades dos presos, como serviços médicos e de } \\
\text { odontologia; (vi) a construção de novos estabelecimentos penitenciários; (vii) } \\
\text { a responsabilização dos responsáveis pela situação indigna dos presos; e (viii) } \\
\text { a realização de estudos e informes mensais a respeito da capacidade } \\
\text { populacional dos estabelecimentos penitenciários. }\end{array}$ \\
\hline $\begin{array}{l}\text { EMENTA OU TRECHO } \\
\text { DESTACADO }\end{array}$ & $\begin{array}{l}\text { Trecho destacado: " } 26 \text {. Tendo em vista tudo o que foi dito, a Quinta Sala de } \\
\text { Revisão da Corte Constitucional reiterará o Estado de Coisas Inconstitucional } \\
\text { no Sistema Penitenciário e Carcerário, declarado na Decisão T-388 de 2013, } \\
\text { como consequência da existência de falhas estruturais, relacionadas } \\
\text { diretamente com a Política Criminal adotada pelo legislador, derivando no } \\
\text { comprometimento de vários direitos fundamentais no país, como se } \\
\text { depreende das verificações efetuadas em cada um dos } 16 \text { centros de reclusão } \\
\text { sobre os quais versa a presente análise" (tradução livre). }\end{array}$ \\
\hline DECISÃO FINAL & 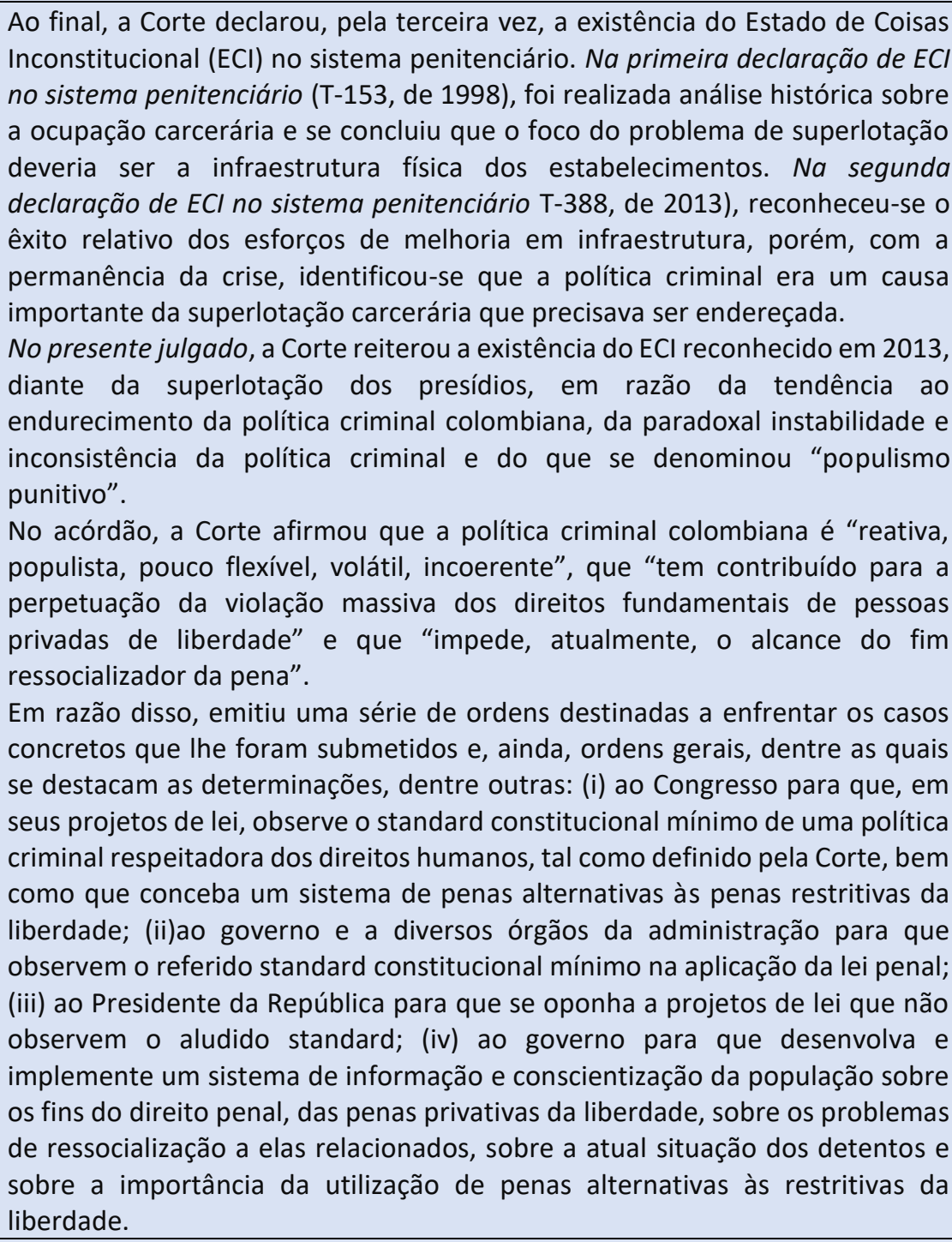 \\
\hline VOTO VENCIDO & Decisão unânime. \\
\hline $\begin{array}{l}\text { PORQUE O CASO É } \\
\text { PARADIGMÁTICO }\end{array}$ & $\begin{array}{l}\text { O caso abrange a situação de } 24.107 \text { reclusos, representantes de } \\
\text { aproximadamente } 20 \% \text { do total da população carcerária, distribuídos por } \\
16 \text { dos } 137 \text { estabelecimentos penitenciários do país. Resume a evolução do }\end{array}$ \\
\hline
\end{tabular}




\begin{tabular}{|l|l|}
\hline & $\begin{array}{l}\text { tratamento dado pela Corte tanto ao instituto do estado de coisas } \\
\text { inconstitucional, quanto ao sistema carcerário como um todo. Indica o } \\
\text { histórico de erros e acertos da Corte na utilização do ECI. }\end{array}$ \\
\hline LINK:<http://www.corteconstitucional.gov.co/relatoria/2015/t\%2D762\%2D15.htm>. \\
\hline PALAVRAS-CHAVE & $\begin{array}{l}\text { ESTADO DE COISAS INCONSTITUCIONAL -SUPERLOTAÇÃO CARCERÁRIA - } \\
\text { SISTEMA PRISIONAL -POPULISMO PUNITIVO -FINS DO DIREITO PENAL -PENAS } \\
\text { ALTERNATIVAS. }\end{array}$ \\
\hline
\end{tabular}

\begin{tabular}{|c|c|}
\hline 3. CASO & $\begin{array}{l}\text { REESTRUTURAÇÃO DO SISTEMA DE SAÚDE } \\
\text { (DIREITO À SAÚDE) }\end{array}$ \\
\hline CLASSE E NÚMERO & $\mathrm{T}-760 / 08^{20}$ \\
\hline ÓRGÃO JULGADOR & Colômbia, Corte Constitucional da Colômbia, Segunda Sala de Revisão \\
\hline RELATOR & Manuel José Cepeda Espinosa \\
\hline REQUERENTES & $\begin{array}{l}\text { O caso reúne } 22 \text { ações de tutela ajuizadas pordiversas pessoas físicas, pela } \\
\text { Personera Distrital Delegada en Derechos Humanos en Cartagenae Entidad } \\
\text { Promotora de Salud - EPS Sanitas SA. }\end{array}$ \\
\hline REQUERIDOS & $\begin{array}{l}\text { Ministerio de la Protección Social; Sala Administrativa del Consejo Superior de } \\
\text { la Judicatura; Departamento Administrativo Distrital de Saúde (DADIS); } \\
\text { Secretaria de Saúde do Departamento de Cesar; Colpatria EPS; SaludCoop EPS; } \\
\text { Seguro Social EPS, Seccional Cesar; Famisanar EPS; Comfenalco EPS; Clínica } \\
\text { Cardiovascular Jesús de Nazareth; Colmédica EPS; ECOOPSOS, Entidad } \\
\text { Cooperativa Solidaria de Salud; Coomeva EPS; Sanitas EPS; Salud total EPS; } \\
\text { Cafesalud EPS; Saludvida EPS. }\end{array}$ \\
\hline DATA DE JULGAMENTO & 31 de julho de 2008 \\
\hline DATA DE PUBLICAÇÃo & Data de publicação não informada. \\
\hline FAtOS & $\begin{array}{l}\text { A Corte aborda ações de tutela sobre o direito à saúde, envolvendo as } \\
\text { denominadas Entidades Promotoras de Saúde (EPS), encarregadas de garantir } \\
\text { a prestação dos serviços de saúde, em diversas situações em que o acesso aos } \\
\text { serviços de saúde requeridos foi negado. }\end{array}$ \\
\hline $\begin{array}{l}\text { FUNDAMENTOS JURÍDICOS } \\
\text { DO PEDIDO }\end{array}$ & $\begin{array}{l}\text { O direito à saúde como um direito constitucional fundamental. Citados vários } \\
\text { dispositivos da Constituição Política da Colômbia }{ }^{21} \text { que fundamentam o dever } \\
\text { estatal de proteção à saúde, relativos à organização das políticas públicas de } \\
\text { saúde (arts. } 48 \text { e } 49)^{22} \text {, ao direito à saúde das pessoas de terceira idade (art. }\end{array}$ \\
\hline
\end{tabular}

${ }^{20}$ COLÔMBIA. Corte Constitucional da Colômbia. T-760/08. Segunda Sala de Revisão. Autor: Personeria Distrital Delegada enDerechos Humanos en Cartagena e outros. Réu: Ministerio de laProtección Social. Relator(a): Manuel José Cepeda Espinosa. Bogotá, 31 de julho de 2008. Disponível em: <http://www.corteconstitucional.gov.co/relatoria/2008/t-760-08.htm>. Acesso em: 03.dez.2017.

21 COLÔMBIA. Constituição Política da Colômbia, de 1991. Disponível em: $<$ http://www.corteconstitucional.gov.co/inicio/Constitucion\%20politica\%20de\%20Colombia\%20\%202015.pdf> Acesso em: 13.out.2017.

${ }^{22}$ COLÔMBIA. Constituição Política da Colômbia, de 1991. "Artigo. 48. A seguridade social é um serviço público obrigatório que deve ser providenciado sob a direção, coordenação e controle do Estado, sujeito a princípios de eficiência, universalidade e solidariedade, nos termos estabelecidos por a lei. Todos os habitantes têm garantido o direito inalienável à Seguridade Social. O Estado, com a participação de indivíduos, expandirá progressivamente a cobertura de seguridade social, que incluirá a prestação de serviços na forma determinada pela Lei. A seguridade social pode ser prestada por entidades públicas ou privadas, em conformidade com a lei. Os recursos das instituições de seguridade social não podem ser alocados ou usados para outros fins que não para a própria seguridade social. A lei definirá os meios para que os recursos destinados a pensões mantenham seu poder de compra constante. [...]. Artigo. 49. Saúde e saneamento ambiental são serviços públicos de responsabilidade do Estado. Todas as pessoas têm acesso garantido aos serviços de promoção, proteção e recuperação da saúde. Cabe ao Estado organizar, direcionar e regular a prestação de serviços de saúde para os habitantes e de saneamento ambiental, de acordo com os princípios 
de eficiência, universalidade e solidariedade. Além disso, estabelecer políticas para a prestação de serviços de saúde por entidades privadas, e exercer sua vigilância e controle. Da mesma forma, estabelecer os poderes da Nação, das entidades e indivíduos e determinar as contribuições para a sua posição nos termos e condições indicadas na lei. Os serviços de saúde serão organizados de forma descentralizada, por níveis de atenção e participação comunitária. A lei descreverá os termos em que os cuidados básicos para todos os habitantes serão gratuitos e obrigatórios. Toda pessoa tem o dever de buscar o cuidado integral de sua saúde e sua comunidade. É proibido o transporte e consumo de substâncias narcóticas ou psicotrópicas, exceto por prescrição médica. Para fins preventivos e reabilitadores, a lei estabelecerá medidas administrativas pedagógicas e tratamentos profiláticos ou terapêuticos para pessoas que consomem essas substâncias. A submissão a estas medidas e tratamentos requer consentimento informado do viciado.

Do mesmo modo, o Estado dedicará atenção especial ao paciente dependente ou adicto e a sua família para fortalecê-los em valores e princípios que contribuam para prevenir comportamentos que afetam os cuidados de saúde integrados das pessoas e, consequentemente, da comunidade, e desenvolverão permanentemente prevenção contra o consumo de drogas ou substâncias narcóticas e em favor da recuperação de viciados" (livre tradução). Disponível em: $<$ http://www.corteconstitucional.gov.co/inicio/Constitucion\%20politica\%20de\%20Colombia.pdf $>$. Acesso em: 1‥dez.2017.

${ }^{23}$ COLÔMBIA. Constituição Política da Colômbia, de 1991. "Artigo. 46. O Estado, a sociedade e a família concorrerão para a proteção e assistência aos idosos e promoverão a sua integração à vida ativa e comunitária. O Estado garantirá os serviços da seguridade social integral e o subsídio alimentar em caso de indigência" (livre tradução). COLÔMBIA. Disponível $<$ http://www.corteconstitucional.gov.co/inicio/Constitucion\%20politica\%20de\%20Colombia.pdf $>$. Acesso em: 1‥dez.2017.

${ }^{24}$ COLÔMBIA. Constituição Política da Colômbia, de 1991. "Artigo. 94. A enunciação dos direitos e garantias contidos na Constituição e nas convenções internacionais em vigor, não devem ser entendidos como uma negação de outros que, sendo inerentes à pessoa humana, não apareçam expressamente neles" (livre tradução). Disponível em: $<$ http://www.corteconstitucional.gov.co/inicio/Constitucion\%20politica\%20de\%20Colombia.pdf>. Acesso em: 1․dez.2017.

25 COLÔMBIA. Constituição Política da Colômbia, de 1991. "Artigo. 228. A Administração da Justiça é uma função pública. Suas decisões são independentes. Sua atuação será pública e permanente, com as exceções que a lei estabeleça e, nela prevalecerá o direito substancial. As normas processuais serão observadas com diligência e a desconformidade será sancionada. Seu funcionamento será descentralizado e autônomo"; "Artigo. 230. Os juízes, nas suas decisões, estão sujeitos apenas ao império da lei.A equidade, a jurisprudência, os princípios gerais de direito e a doutrina são critérios auxiliares de atividade judicial" (livre tradução). Disponível em: <http://www.corteconstitucional.gov.co/inicio/Constitucion\%20politica\%20de\%20Colombia.pdf>. Acesso em: 1‥dez.2017. 


\begin{tabular}{|c|c|}
\hline & $\begin{array}{l}\text { social dos serviços públicos (arts. } 365 \text { e } 366)^{26} \text {; bem como a Lei } 100 \text { de } 1993^{27} \text {, } \\
\text { referente ao Sistema de Seguridade Social colombiano; oPacto Internacional } \\
\text { sobre Direitos Econômicos, Sociais e Culturais (PIDESC) }{ }^{28} \text {, que prevê, no art. } 12 \text {, } \\
\text { o direito de toda pessoa de desfrutar do mais alto nível possível de saúde física } \\
\text { e mental; e a Convenção } 169 \text { da } \operatorname{OIT}^{29} \text {, no que respeita aos serviços de saúde } \\
\text { pertinente aos povos indígenas. No caso de EPS Sanitas SA, a ação de tutela foi } \\
\text { fundamentada na violação do direito de petição consagrado no art. } 23 \text { da } \\
\text { Constituição Política da Colômbia }{ }^{30} \text {. }\end{array}$ \\
\hline PedIDo & $\begin{array}{l}\text { Os pedidos envolvem o acesso aos serviços de saúde como direito } \\
\text { fundamental, bem como o direito de petição. }\end{array}$ \\
\hline $\begin{array}{l}\text { EMENTA OU TRECHO } \\
\text { DESTACADO }\end{array}$ & $\begin{array}{l}\text { "DIREITO À SAÚDE -É um direito fundamental; [...] Compreende, entre outros, } \\
\text { o direito de acesso a serviços de saúde de maneira oportuna, eficaz e com } \\
\text { qualidade; [...]; Reforma, atualização periódica e adequação para que o POS e } \\
\text { o POSS respondam às necessidade de saúde da população; [...] Corte } \\
\text { Constitucional ordena adotar um plano de contingência para assegurar a } \\
\text { recuperação dos pagamentos atrasados ao FOSYGA; [...]; Corte Constitucional } \\
\text { ordena proteger o direito à informação, mediante a distribuição às pessoas } \\
\text { afiliadas de uma carta de direitos dos usuários e uma carta de desempenho das } \\
\text { entidades do setor de saúde; [...] Corte Constitucional ordena adotar medidas } \\
\text { para que progressivamente se alcance a cobertura universal do Sistema antes } \\
\text { de janeiro de } 2010 ;[\ldots] \text { Indicadores de gestão e de resultados no âmbito da } \\
\text { saúde devem incorporar o índice do gozo efetivo do direito à saúde por parte } \\
\text { das pessoas; [...] Corte Constitucional ordena que antes de } 1^{\circ} \text { de fevereiro de } \\
2009 \text { seja apresentado o primeiro informe sobre a redução de ações de tutela; } \\
\text { [...] Determinação da capacidade econômica em cada caso concreto e o } \\
\text { conceito de carga suportável; [...] Acesso aos serviços de saúde demandados }\end{array}$ \\
\hline
\end{tabular}

${ }^{26}$ COLÔMBIA. Constituição Política da Colômbia, de 1991. “Artigo 365. Os serviços públicos são inerentes ao fim social do Estado. É dever do Estado assegurar sua prestação eficiente a todos os habitantes do território nacional. Os serviços públicos estarão submetidos ao regime jurídico fixado em lei, poderão ser prestados pelo Estado, direta ou indiretamente, por comunidades organizadas, ou por particulares. Em todo caso, o Estado manterá a regulação, o controle e a vigilância de ditos serviços. Se, por razões de soberania ou de interesse social, o Estado, mediante lei aprovada pela maioria dos membros de uma e outra câmara, por iniciativa do Governo, decidir reservar-se determinadas atividades estratégicas ou serviços públicos, deverá indenizar prévia e plenamente as pessoas que em virtude de dita lei sejam privadas do exercício de uma atividade lícita"; "Artigo 366. O bem-estar geral e o melhoramento da qualidade de vida da população são finalidades sociais do Estado. Será objetivo fundamental de sua atuação a solução das necessidades insatisfeitas de saúde, de educação, de saneamento ambiental e de água potável. Para tais efeitos, nos programas e orçamentos da Nação e das entidades territoriais, o gasto público social terá prioridade sobre qualquer outra alocação" (livre tradução). Disponível em: $<$ http://www.corteconstitucional.gov.co/inicio/Constitucion\%20politica\%20de\%20Colombia.pdf>. Acesso em: 1‥dez.2017.

27 COLÔMBIA, Lei 100, de $1993 . \quad$ Disponível em: <http://www.alcaldiabogota.gov.co/sisjur/normas/Norma1.jsp?i=5248>. Acesso em: 14.mai.2017.

28 ORGANIZAÇÃO DAS NAÇÕES UNIDAS (ONU). Pacto Internacional sobre Direitos Econômicos, Sociais $e$ Culturais. Disponível em: <http://www.ohchr.org/Documents/Professionallnterest/cescr.pdf >. Acesso em: 14.mai.2017.

29 ORGANIZAÇÃO INTERNACIONAL DO TRABALHO (OIT). Convenção n. 169. Disponível em: $<$ http://www.ilo.org/brasilia/convencoes/WCMS 236247/lang--pt/index.htm>. Acesso em: 13.out.2017.

${ }^{30}$ COLÔMBIA. Constituição Política da Colômbia, de 1991. "Artigo 23. Toda pessoa tem o direito de apresentar petições que digam respeito às autoridades por razões de interesse geral ou particular e obter uma pronta solução. O legislador pode regular o seu exercício perante organizações privadas para garantir os direitos fundamentais." (Livre tradução). Disponível em: $<$ http://www.corteconstitucional.gov.co/inicio/Constitucion\%20politica\%20de\%20Colombia.pdf>. Acesso em: 1‥dez.2017. 


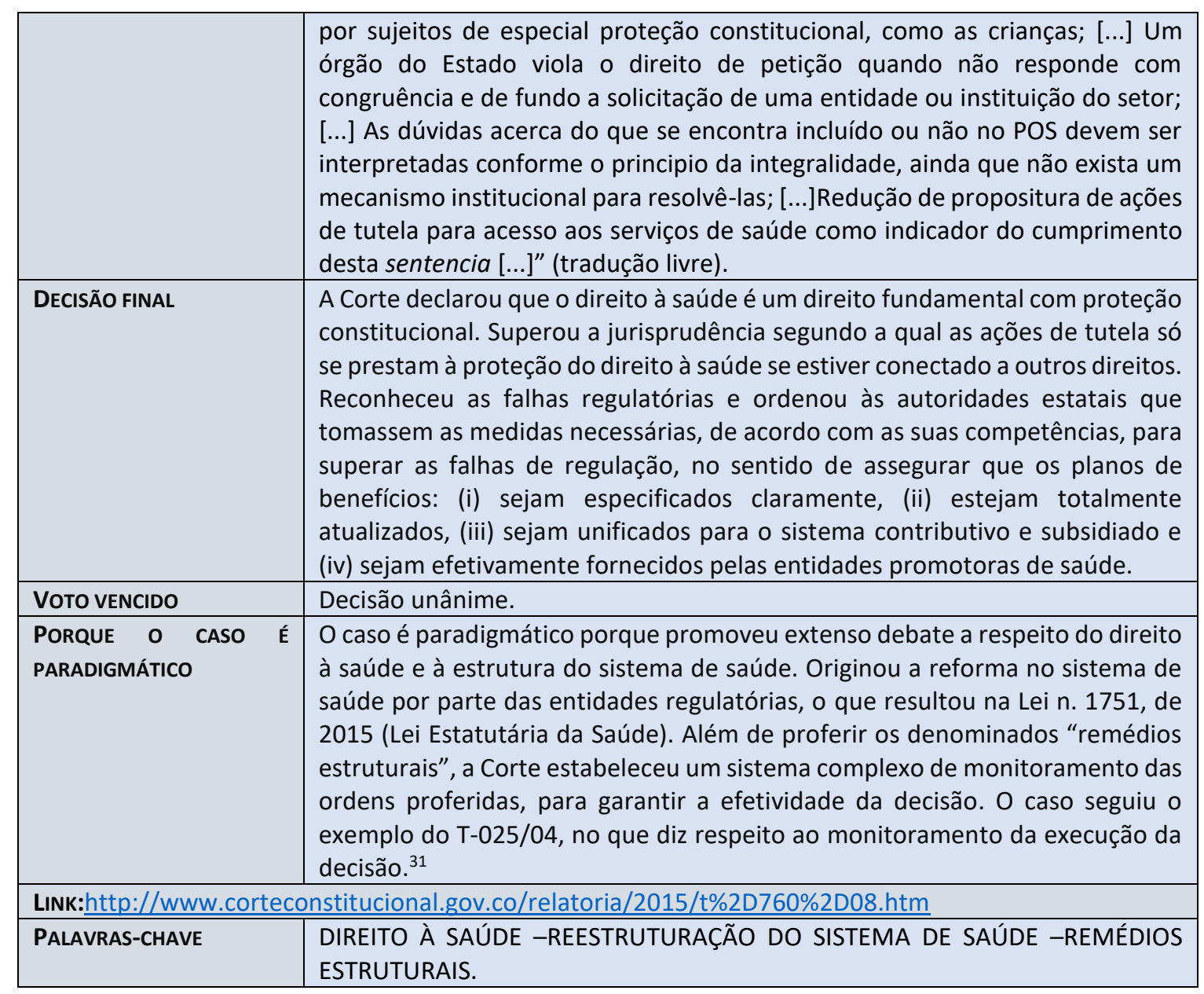

\begin{tabular}{|l|l|}
\hline 4. CASO & $\begin{array}{l}\text { VENDEDORES AMBULANTES DE BOGOTÁ } \\
\text { (DIREITO AO TRABALHO) }\end{array}$ \\
\hline CLASSE E NÚMERO & SU-360/9932 \\
\hline ÓRGÃo JULGADOR & Colômbia, Corte Constitucional da Colômbia, Sala Plena \\
\hline RELATOR & Alejandro Martinez Caballero \\
\hline REQUERENTE & $\begin{array}{l}\text { Ana Mercedes Martínez de García e outros 1.015 vendedores ambulantes de } \\
\text { diversas localidades de Bogotá }\end{array}$ \\
\hline REQUERIDO & Governador Maior de Bogotá e governadores locais \\
\hline DATA DEJULGAMENTO & 19 de maio de 1999 \\
\hline DATA DE PUBLICAÇÃo & Data de publicação não informada. \\
\hline FATOS & $\begin{array}{l}\text { O caso é representativo de um conjunto de ações de tutela ajuizadas contra a } \\
\text { administração local, por comerciantes da região de Santafé de Bogotá, que } \\
\text { exerceram ou exerciam o comércio informal em espaço público. Na gestão }\end{array}$ \\
\hline
\end{tabular}

${ }^{31}$ ESPINOSA, Manuel José Cepeda, LANDAU, David. Colombian Constitutional Law: leading cases. New York: Oxford University Press, 2017. p. 172-178.

32 COLÔMBIA. Corte Constitucional da Colômbia. SU-360/99. Sala Plena. Autor: Ana Mercedes Martínez de García e outros. Réu: Governador Maior de Bogotá e outros. Relator(a): Alejandro Martinez Caballero. Bogotá, 19 de maio de 1999. Disponível em: <http://www.corteconstitucional.gov.co/RELATORIA/1999/SU36099.htm>. Acesso em: 03.dez.2017.

Revista Publicum

Rio de Janeiro, v. 3, n. 2, 2017, p. 286-338

http://www.e-publicacoes.uerj.br/index.php/publicum DOI: $10.12957 /$ publicum.2017.31883 


\begin{tabular}{|c|c|}
\hline & $\begin{array}{l}\text { anterior, os comerciantes haviam iniciado tratativas referentes a um possível } \\
\text { acordo que visava a estabelecer a organização da comunidade de vendedores } \\
\text { que atuavam nas ruas da região. Porém, a gestão seguinte desconsiderou as } \\
\text { tratativas da gestão anterior e iniciou o processo de desalojamento dos } \\
\text { trabalhadores de rua, com base em seu poder de polícia. Em razão disso, os } \\
\text { comerciantes informais ajuizaram demandas de tutela alegando violação do } \\
\text { direito ao trabalho, que resultaram no presente caso. }\end{array}$ \\
\hline $\begin{array}{l}\text { FUNDAMENTOS JURÍDICOS } \\
\text { DO PEDIDO }\end{array}$ & $\begin{array}{l}\text { Os requerentes alegam violação aos direitos constitucionais consagrados nos } \\
\text { arts. } 13^{33}, 25^{34} \text { e } 44^{35} \text { da Constituição Política da Colômbia, destacando o } \\
\text { direito adquirido pelo Acordo n. } 4 \text {, de 1995, celebrado com a Junta } \\
\text { Administradora Local (na administração anterior), o direito ao trabalho em } \\
\text { condições dignas e justas, o direito à igualdade na execução dos projetos do } \\
\text { Plano de Desenvolvimento, o direito à dignidade humana e os direitos dos } \\
\text { menores, dependentes do sustento derivado do trabalho dos seus pais. }\end{array}$ \\
\hline Pedido & $\begin{array}{l}\text { Os demandantes postularam a proteção ao direito de trabalhar em espaços } \\
\text { públicos sem serem removidos pela autoridade local }\end{array}$ \\
\hline $\begin{array}{l}\text { EMENTA OU TRECHO } \\
\text { DESTACADO }\end{array}$ & $\begin{array}{l}\text { "Primeiro. conceder a tutela aos vendedores ambulantes da Localidade de } \\
\text { Fontibón, relacionados no capítulo "Casos concretos" deste caso, em razão de } \\
\text { lhes ter sido violado o direito ao trabalho, dentro do contexto assinalado na } \\
\text { fundamentação, e, em consequência, se revogam as sentenças proferidas } \\
\text { pelos juízes de instância [...]."'Décimo segundo: ordem de prevenção ao } \\
\text { Alcaide Maior do Distrito da Capital e aos Alcaides Locais desta cidade para }\end{array}$ \\
\hline
\end{tabular}

${ }^{33}$ COLÔMBIA. Constituição Política da Colômbia, de 1991. "Artigo 13. Todas as pessoas nascem livres e iguais perante a lei, receberão a mesma proteção e tratamento das autoridades e gozarão dos mesmos direitos, liberdades e oportunidades, sem nenhuma discriminação por razões de sexo, raça, origem nacional ou familiar, língua, religião, opinião política ou filosófica. O Estado promoverá as condições para que a igualdade seja real e efetiva e adotará medidas em favor de grupos discriminados ou marginalizados. O Estado protegerá especialmente aquelas pessoas que por sua condição econômica, física ou mental se encontrem em circunstância de debilidade manifesta e sancionará os abusos ou maus tratos que contra elas se cometam" (livre tradução). Disponível em: <http://www.corteconstitucional.gov.co/inicio/Constitucion\%20politica\%20de\%20Colombia.pdf>. Acesso em: 1‥dez.2017.

${ }^{34}$ COLÔMBIA. Constituição Política da Colômbia, de 1991. "Artigo 25. O trabalho é um direito e uma obrigação social e goza, em todas as suas modalidades, da proteção especial do Estado. Todos têm o direito a um trabalho em condições decentes e justas" (livre tradução). Disponível em: $<$ http://www.corteconstitucional.gov.co/inicio/Constitucion\%20politica\%20de\%20Colombia.pdf >. Acesso em: 1‥dez.2017.

35 COLÔMBIA. Constituição Política da Colômbia, de 1991. "Artigo 44. São direitos das crianças: a vida, a integridade física, a saúde e a seguridade social, a alimentação equilibrada, seu nome e nacionalidade, ter uma família e não ser dela separada, o cuidado e o amor, a educação e a cultura, a recreação e a livre expressão de sua opinião. Serão protegidas contra toda forma de abandono, violência física ou moral, sequestro, venda, abuso sexual, exploração laboral ou econômica e trabalhos perigosos. Gozarão também dos demais direitos consagrados na Constituição, nas leis e nos tratados internacionais ratificados pela Colômbia"; "Artigo 68. Os particulares poderão fundar estabelecimentos educativos. A lei estabelecerá as condições para sua criação e gestão. A comunidade educativa participará da direção das instituições de educação. O ensino estará a cargo de pessoas de reconhecida idoneidade ética e pedagógica. A Lei garantirá a profissionalização e dignificação da atividade docente. Os pais de família terão direito de escolher o tipo de educação para seus filhos menores. Nos estabelecimentos do Estado nenhuma pessoa poderá ser obrigada a receber educação religiosa. Os integrantes dos grupos étnicos terão direito a uma formação que respeite e desenvolva sua identidade cultural. A erradicação do analfabetismo e a educação de pessoas com limitações físicas ou mentais, ou com capacidades excepcionais, são obrigações especiais do Estado" (livre tradução). Disponível $<$ http://www.corteconstitucional.gov.co/inicio/Constitucion\%20politica\%20de\%20Colombia.pdf>. Acesso em: 1‥dez.2017. 


\begin{tabular}{|c|c|}
\hline & $\begin{array}{l}\text { que, doravante, antes de procederem ao desalojamento, busquem tanto } \\
\text { quanto possível, soluções de realocação ou outras opções, conjuntamente com } \\
\text { os ocupantes do espaço público, amparados pela confiança legítima, nos } \\
\text { termos assinalados nesta providência. [...]Décimo Terceiro: Aos mesmos } \\
\text { funcionários assinalados no item anterior, ao comandante de polícia } \\
\text { metropolitana de Bogotá, aos comandantes das zonas de Bacatá, Tisquesusa e } \\
\text { Tequendama e aos responsáveis da estação da polícia nacional, ao secretário } \\
\text { de governo do Distrito Capital lhes é dirigida ordem de prevenção para que, } \\
\text { em cumprimento de suas funções (publicação) não atentem contra a dignidade } \\
\text { das pessoas ou contra a propriedade dos bens de que são titulares" (tradução } \\
\text { livre). }\end{array}$ \\
\hline DECISÃO FINAL & $\begin{array}{l}\text { Ao final, a Corte concedeu a tutela aos comerciantes informais de várias } \\
\text { localidades que provaram a violação do direito ao trabalho por parte da } \\
\text { municipalidade. Recomendou que as prefeituras, antes de procederem ao } \\
\text { desalojamento, busquem, sempre que possível, soluções de relocação e ou } \\
\text { outras opções, conjuntamente com os ocupantes do espaço público, } \\
\text { amparados pela confiança legítima, bem como determinou às autoridades } \\
\text { que, no cumprimento de suas funções de proteção do bem público, não } \\
\text { atentem contra a dignidade das pessoas ou contra a propriedades dos bens de } \\
\text { que são titulares. }\end{array}$ \\
\hline VOTO VENCIDO & Não há. \\
\hline $\begin{array}{l}\text { PORQUE O CASO É } \\
\text { PARADIGMÁTICO }\end{array}$ & $\begin{array}{l}\text { O caso é paradigmático pois representa a opção da Corte em exaltar a } \\
\text { obrigação estatal de promover condições de trabalho aos menos favorecidos } \\
\text { - isto é, a afirmação do princípio da proteção do trabalhador - em detrimento } \\
\text { da proteção do espaço público. }\end{array}$ \\
\hline \multicolumn{2}{|c|}{ LINK:http://www.corteconstitucional.gov.co/relatoria/1999/su360\%2D99.htm } \\
\hline PALAVRAS-CHAVE & $\begin{array}{l}\text { DIREITO AO TRABALHO - TRABALHO INFORMAL - CONFIANÇA LEGÍTIMA - } \\
\text { BENS DE USO PÚBLICO - DEVER DO ESTADO DE PROMOVER CONDIÇÕES DE } \\
\text { TRABALHO DIGNO. }\end{array}$ \\
\hline 5. CASO & $\begin{array}{l}\text { ABORTO } \\
\text { (DIREITO À SAÚDE, À AUTONOMIA E VEDAÇÃO AO TRATAMENTO CRUEL) }\end{array}$ \\
\hline CLASSE E NÚMERO & $C-355 / 06^{36}$ \\
\hline ÓRGÃO JULGADOR & Colômbia, Corte Constitucional da Colômbia, Sala Plena \\
\hline RELATOR & Jaime Araújo Rentería e Clara Inés Vargas Hernandez \\
\hline REQUERENTES & $\begin{array}{l}\text { Mónica del Pilar Roa López, Pablo Jaramillo Valencia, Marcela Abadía Cubillos, } \\
\text { Juana Dávila Sáenz e Laura Porras Santillana }\end{array}$ \\
\hline REQUERIDO & Não informados. \\
\hline DATA DEJULGAMENTO & 10 de maio de 2006 \\
\hline DATA DE PUBLICAÇÃO & Data de publicação não informada. \\
\hline FATOS & $\begin{array}{l}\text { O caso é representativo de um conjunto de demandas de constitucionalidade } \\
\text { propostas por cidadãos, visando à declaração de inconstitucionalidade de } \\
\text { dispositivos do Código Penal colombiano que criminalizavam o aborto. São } \\
\text { objeto do juízo de constitucionalidade os seguintes dispositivos da Lei n. } 599 \\
\text { de } 2000 \text { (Código Penal): arts. } 122,123 \text { (parcial), } 124 \text { e } 32 \text {, numeral } 7^{37} \text {. }\end{array}$ \\
\hline
\end{tabular}

${ }^{36}$ COLÔMBIA. Corte Constitucional da Colômbia. C-355/06. Sala Plena. Autor: Mónica del Pilar Roa López e outros. Relatores: Jaime Araújo Rentería e Clara Inés Vargas Hernandez. Bogotá, 10 de maio de 2006. Disponível em: <http://www.corteconstitucional.gov.co/relatoria/2006/c-355-06.htm>. Acesso em: 03.dez.2017.

37 COLÔMBIA. Lei 599, de 2000, Código Penal. "Artigo 32. Ausência de responsabilidade. Não haverá responsabilidade criminal quando: 7. Atuamos pela necessidade de proteger o direito próprio ou de alguém

Revista Publicum

Rio de Janeiro, v. 3, n. 2, 2017, p. 286-338

http://www.e-publicacoes.uerj.br/index.php/publicum

DOI: $10.12957 /$ publicum.2017.31883 
FUnDAMENTOS JURíDıcos $\quad$ Alegada a violação ao preâmbulo e aos arts. $1^{\circ}, 11,12,13,15,16,42,43$, 49 e

DO PEDIDO $\quad 93$, numeral segundo, da Constituição Política da Colômbia ${ }^{38}$, por desrespeito:

a um perigo atual ou iminente, inevitável de outra forma, que o agente não tenha causado intencionalmente ou imprudentemente e que não tenha o dever legal de enfrentar"; "Artigo 122. Aborto. A mulher que causa seu aborto ou permite que outro o cause, terá uma pena de prisão de um (1) a três (3) anos"; "Artigo 123. Aborto sem consentimento. Aquele que provoca o aborto sem o consentimento da mulher ou de uma mulher com menos de quatorze anos, terá uma pena de prisão de quatro (4) a dez (10) anos"; "Artigo 124. Circunstâncias de atenuação punitiva. A penalidade indicada para o crime de aborto será reduzida em três quartos quando a gravidez for o resultado de uma conduta que constitua uma relação sexual sem consentimento, abuso, inseminação artificial ou transferência de óvulo fertilizado sem consentimento" (tradução livre). Disponível em:<http://www.alcaldiabogota.gov.co/sisjur/normas/Norma1.jsp?i=6388>. Acesso em: 14.out.2017.

${ }^{38}$ COLÔMBIA. Constituição Política da Colômbia. "Preâmbulo. O povo da Colômbia, no exercício de seu poder soberano, representado por seus delegados na Assembleia Nacional Constituinte, invocando a proteção de Deus e a fim de fortalecer a unidade da Nação e garantir a sua vida, coexistência, trabalho, justiça, igualdade, conhecimento, liberdade e paz, dentro de um quadro legal, democrático e participativo que garanta uma ordem política, econômica e social justa e comprometido com a promoção da integração da comunidade latino-americana, decretos, sanciona e promulga o seguinte: CONSTITUIÇÃO POLÍTICA DA COLÔMBIA. Artigo 1‥ A Colômbia é um Estado social de direito organizado sob a forma de uma República unitária e descentralizada, com autonomia de suas entidades territoriais, democrática, participativa e pluralista, baseada no respeito à dignidade humana, ao trabalho e à solidariedade do povo que a integram e na prevalência do interesse geral. [...]. Artigo 11. O direito à vida é inviolável. Não haverá pena de morte. Artigo 12. Ninguém deve ser submetido a desaparecimento forçado, tortura ou tratamento ou punição cruel, desumano ou degradante. Artigo 13. Todas as pessoas nascem livres e iguais perante a lei, receberão a mesma proteção e tratamento das autoridades e gozarão dos mesmos direitos, liberdades e oportunidades, sem nenhuma discriminação por razões de sexo, raça, origem nacional ou familiar, língua, religião, opinião política ou filosófica. O Estado promoverá as condições para que a igualdade seja real e efetiva e adotará medidas em favor de grupos discriminados ou marginalizados. O Estado protegerá especialmente aquelas pessoas que por sua condição econômica, física ou mental se encontrem em circunstância de debilidade manifesta e sancionará os abusos ou maus tratos que contra elas se cometam. [...]. Artigo 15. Todas as pessoas têm direito à sua intimidade pessoal e familiar e a seu bom nome, e o Estado deve respeitá-los e fazer com que sejam respeitados. De igual modo, têm direito a conhecer, atualizar e retificar as informações obtidas sobre elas em bancos de dados e em arquivos de entidades públicas e privadas. Na cobrança, no tratamento e na circulação da liberdade de dados, as garantias consagradas na Constituição serão respeitados. A correspondência e outras formas de comunicação privada são invioláveis. Eles só podem ser interceptados ou registrados por ordem judicial, nos casos e nas formalidades estabelecidas por lei. Para fins fiscais ou judiciais e para casos de inspeção, vigilância e intervenção do Estado, a apresentação de livros contábeis e outros documentos privados podem ser exigidos nos termos estabelecidos por lei. Artigo 16. Todas as pessoas têm direito ao livre desenvolvimento de sua personalidade sem limitações além das impostas pelos direitos de terceiros e pela ordem jurídica. [...]. Artigo 42. A família é o núcleo fundamental da sociedade. É constituído por laços naturais ou legais, pela livre decisão de um homem e uma mulher para casar ou pela vontade responsável de conformá-lo. O Estado e a sociedade garantem a proteção integral da família. A lei pode determinar o patrimônio familiar inalienável e não embargável. A honra, dignidade e intimidade da família são invioláveis. As relações familiares são baseadas na igualdade de direitos e deveres do casal e respeito recíproco entre todos os seus membros. Qualquer forma de violência na família é considerada destrutiva de sua harmonia e unidade, e será sancionada de acordo com a lei. As crianças nascidas dentro ou fora do casamento, adotadas ou procriadas naturalmente ou com assistência científica, têm direitos e deveres iguais. A lei regulará a prole responsável. O casal tem o direito de decidir de forma livre e responsável o número de filhos que terá e deve apoiá-los e educá-los enquanto são menores ou incapacitados. As formas de casamento, a idade e a capacidade de contraí-lo, os deveres e direitos dos cônjuges, a sua separação e a dissolução do vínculo são regidos pelo direito civil. Casamentos religiosos terão efeitos civis nos termos estabelecidos por lei. Os efeitos civis de qualquer casamento cessarão por meio do divórcio de acordo com o direito civil. Os julgamentos civis de nulidade de casamentos religiosos ditados pelas autoridades da respectiva religião também terão efeitos civis, nos termos estabelecidos por lei. A lei disporá sobre o estado civil das pessoas e os direitos e deveres consequentes. Artigo 43. Mulheres e homens têm direitos e oportunidades iguais. A mulher não pode ser submetida a nenhum tipo de discriminação. Durante a gravidez e após o parto, ela gozará de assistência e

Revista Publicum

Rio de Janeiro, v. 3, n. 2, 2017, p. 286-338

http://www.e-publicacoes.uerj.br/index.php/publicum

DOI: $10.12957 /$ publicum.2017.31883 


\begin{tabular}{|c|c|}
\hline & $\begin{array}{l}\text { (i) ao direito à dignidade, à autonomia reprodutiva e ao livre desenvolvimento } \\
\text { da personalidade; (ii) ao princípio da proporcionalidade; (iii) ao direito à } \\
\text { igualdade; (iv) à vedação aos tratamentos cruéis, desumanos e degradantes } \\
\text { (no contexto de malformação fetal); (v) ao direito à dignidade humana; (vi) ao } \\
\text { direito à saúde e à vida da mãe e à integridade; (vii) ao direito à intimidade. }\end{array}$ \\
\hline Pedido & $\begin{array}{l}\text { Os demandantes postularam a declaração de inconstitucionalidade de } \\
\text { dispositivos do Código Penal colombiano que criminalizavam o aborto. }\end{array}$ \\
\hline $\begin{array}{l}\text { EMENTA OU TRECHO } \\
\text { DESTACADO }\end{array}$ & $\begin{array}{l}\text { "No ordenamento constitucional a vida tem diferentes tratamentos, podendo- } \\
\text { se distinguir o direito à vida consagrado no art. } 11 \text { da Constituição, da vida } \\
\text { como bem jurídico protegido pela Constituição. O direito à vida pressupõe a } \\
\text { titularidade para seu exercício e a titularidade, como a de todos os direitos, } \\
\text { está restrita à pessoa humana, ao passo que a proteção à vida é aplicável } \\
\text { inclusive em favor daqueles que ainda não alcançaram essa condição [de } \\
\text { pessoa humana]. [...]. A vida humana transcorre em distintas etapas e se } \\
\text { manifesta de diferentes formas, que, por sua vez, são objeto de proteção } \\
\text { diferenciada. Embora o ordenamento jurídico proteja o nascituro, não o } \\
\text { protege com a mesma intensidade com quem protege a pessoa humana. Tanto } \\
\text { é assim que na maior parte das legislações é maior a pena para infanticídio e } \\
\text { homicídio que para o aborto. É dizer: o bem jurídico tutelado não é o mesmo } \\
\text { em todos os casos [...]. ABORTO - A proibição total é inconstitucional. [...], a } \\
\text { penalização do aborto em todas as circunstâncias implica a completa } \\
\text { preponderância de um dos bens em jogo, a vida do nascituro, e do } \\
\text { consequente sacrifício de outros direitos fundamentais da gestante, o que a } \\
\text { toda evidência é inconstitucional. [...]. ABORTO - Incesto. A dignidade da } \\
\text { mulher exclui a possibilidade de que seja considerada um mero receptáculo e } \\
\text { por isso exige-se o consentimento para que ela assuma compromisso ou } \\
\text { obrigação de tamanho relevo neste caso, diante de um fato de tamanha } \\
\text { transcendência, como o dar a vida a um novo ser, vida que afetará } \\
\text { profundamente à vida da mulher em todos os sentidos. A gestação decorrente }\end{array}$ \\
\hline
\end{tabular}

proteção especial do Estado, e receberá alimento subsidiado se ela estiver desempregada ou desamparada naquele momento. O Estado apoiará de forma especial a mulher chefe da família. [...]. Artigo 49. Os cuidados de saúde e o saneamento ambiental são serviços públicos prestados pelo Estado. Todas as pessoas têm acesso garantido a serviços de promoção, proteção e recuperação de saúde. Cabe ao Estado organizar, direcionar e regular a prestação de serviços de saúde aos habitantes e saneamento ambiental de acordo com os princípios de eficiência, universalidade e solidariedade. Além disso, estabelecer políticas para a prestação de serviços de saúde por entidades privadas e exercer sua vigilância e controle. Da mesma forma, estabelecer os poderes da Nação, entidades territoriais e indivíduos e determinar as contribuições para a sua posição nos termos e condições indicados na lei. Os serviços de saúde serão organizados de forma descentralizada, por níveis de atendimento e com participação comunitária. A lei indicará os termos em que os cuidados básicos para todos os habitantes serão gratuitos e obrigatórios. Toda pessoa tem o dever de procurar o cuidado integral de sua saúde e a de sua comunidade. [...]. Artigo 93. Os tratados e convenções internacionais ratificados pelo Congresso que reconhecem os direitos humanos e proíbem sua limitação nos estados de exceção prevalecem na ordem interna. Os direitos e deveres consagrados nesta Carta serão interpretados de acordo com os tratados internacionais sobre direitos humanos ratificados pela Colômbia. O Estado colombiano pode reconhecer a jurisdição do Tribunal Penal Internacional, nos termos estabelecidos no Estatuto de Roma adotado em 17 de julho de 1998 pela Conferência de Plenipotenciários das Nações Unidas, e, consequentemente, ratificar este tratado de acordo com o procedimento estabelecido nesta Constituição. (Texto atual em decorrência do artigo 1ㅇdo Ato Legislativo no 2 de 2001.) A admissão de um tratamento diferente em matéria substancial pelo Estatuto de Roma com respeito às garantias contidas na Constituição terá efeitos exclusivamente no âmbito da matéria regulamentada no mesmo. (Texto atual em decorrência do artigo 1o do Ato Legislativo no 2 de 2001.)" (livre tradução). Disponível em: $<$ http://www.corteconstitucional.gov.co/inicio/Constitucion\%20politica\%20de\%20Colombia\%20\%202015.pdf>. Acesso em: 12.out.2017.

Revista Publicum

Rio de Janeiro, v. 3, n. 2, 2017, p. 286-338

http://www.e-publicacoes.uerj.br/index.php/publicum

DOI: 10.12957/publicum.2017.31883 


\begin{tabular}{|c|c|}
\hline & $\begin{array}{l}\text { de incesto decorre de conduta punível que muitas vezes compromete o } \\
\text { consentimento e a vontade da mulher. [...]. ABORTO - Procedência quando a } \\
\text { gestação resulta de ato sexual, de inseminação artificial ou de transferência de } \\
\text { óvulo não consentidos. [...]. ABORTO - Procedência quando esteja em risco a } \\
\text { saúde física ou mental da mãe. ABORTO - Procedência quando existe grave } \\
\text { malformação do feto que implica na inviabilidade de vida extrauterina. [...]" } \\
\text { (tradução livre). }\end{array}$ \\
\hline DECISÃO FINAL & $\begin{array}{l}\text { Ao final, a Corte declarou a inconstitucionalidade do crime de aborto em } \\
\text { determinadas circunstâncias: (i) quando a gravidez implicar ameaça à saúde da } \\
\text { gestante, atestada por médico; (ii) quando houver malformação fetal capaz de } \\
\text { comprometer a vida pós-uterina do feto, atestada por médico; (iii) quando a } \\
\text { gravidez decorrer de estupro, incesto ou inseminação artificial sem } \\
\text { consentimento, desde que seja informada a conduta criminosa à autoridade } \\
\text { competente. }\end{array}$ \\
\hline VOTO VENCIDO & $\begin{array}{l}\text { Votos destacados: Jaime AraujoRentería e Manuel Cepeda Espinosa.Votos } \\
\text { vencidos: Rodrigo Escobar Gil, Marco Gerado Monroy Cabra e Álvaro } \\
\text { RafurGávis. }\end{array}$ \\
\hline $\begin{array}{l}\text { PORQUE O CASO É } \\
\text { PARADIGMÁTICO }\end{array}$ & $\begin{array}{l}\text { O caso é paradigmático pois representa a interferência da Corte na liberdade } \\
\text { de conformação legislativa, com base não só em aspectos individuais - como a } \\
\text { dignidade, a autodeterminação reprodutiva e intimidade - mas, também, com } \\
\text { base em aspectos sociais - como o direito à saúde e ao planejamento familiar. }\end{array}$ \\
\hline \multicolumn{2}{|c|}{ LINK:http://www.corteconstitucional.gov.co/relatoria/2006/c\%2D355\%2D06.htm } \\
\hline PALAVRAS-CHAVE & $\begin{array}{l}\text { ABORTO - (DES)CRIMINALIZAÇÃO - DIREITO À SAÚDE -INVIABILIDADE EXTRA } \\
\text { UTERINA - ESTUPRO - INCESTO -INSEMINAÇÃO - RISCO À SAÚDE FÍSICA - } \\
\text { RISCO À SAÚDE MENTAL - IGUALDADE DE GÊNERO. }\end{array}$ \\
\hline
\end{tabular}

\begin{tabular}{|c|c|}
\hline 6. CASO & $\begin{array}{l}\text { DIREITO À ÁGUA } \\
\text { (DIREITO À VIDA DIGNA, À SAÚDE E À ÁGUA) }\end{array}$ \\
\hline CLASSE E NÚMERO & $\mathrm{T}-616 / 10^{39}$ \\
\hline ÓRGÃO JULGADOR & Colômbia, Corte Constitucional, Nona Sala de Revisão \\
\hline RELATOR & Luis Ernesto Vargas Silva \\
\hline REQUERENTES & $\begin{array}{l}\text { Hernán Galeano Días (T-2.456.550); Marco Gómez Otero, Dagoberto Valbuena, } \\
\text { Benita Balanta, Horacio Cárdenas, Juan E. Copete, Libardo Gómez, Marta } \\
\text { Montaño, María de Jesús Montaño, Fernando Hernán Naranjo, Bezabeth Olaya } \\
\text { Paneso, Adriana Rodríguez e Leonor Valencia Cuero (T- 2.456.678). }\end{array}$ \\
\hline REQUERIDOS & $\begin{array}{l}\text { Empresas Públicas de Medellín E.S.P (T-2.456.550); Hidropacífico S.A E.S.P, } \\
\text { Sociedad de Acueducto, Alcantarillado de Buenaventura e Alcaldía de } \\
\text { Buenaventura - Valle (T-2.456.678). }\end{array}$ \\
\hline DATA DE JULGAMENTO & 5 de agosto de 2010 \\
\hline DATA DE PUBLICAÇÃO & Data de publicação não informada. \\
\hline FATOS & $\begin{array}{l}\text { As ações de tutela se insurgem contra as deficiências na prestação de serviços } \\
\text { de fornecimento de água: (i) na primeira, o autor afirma que mora com sua } \\
\text { família na cidade de Medellín, que não dispõe de fornecimento de água ou de } \\
\text { rede de esgoto necessárias ao atendimento das suas necessidades básicas ( } T \text { - }\end{array}$ \\
\hline
\end{tabular}

${ }^{37}$ Nesse caso, a Corte decidiu julgar em conjunto as ações de tutela T-2.456.550 e T-2.456.678, por se tratar da mesma matéria.COLÔMBIA. Corte Constitucional da Colômbia. T-616/10. Nona Sala de Revisão. Autor: Hernán Galeano Días e outros. Réu: Empresas Públicas de Medellín E.S.P e outros. Relator: Luis Ernesto Vargas Silva. Bogotá, 5 de agosto de 2010. Disponível em: <http://www.corteconstitucional.gov.co/relatoria/2010/T616-10.htm>. Acesso em: 7.dez.2017.

Revista Publicum

Rio de Janeiro, v. 3, n. 2, 2017, p. 286-338

http://www.e-publicacoes.uerj.br/index.php/publicum

DOI: 10.12957/publicum.2017.31883 


\begin{tabular}{|c|c|}
\hline & $\begin{array}{l}2.456 .550) \text {; (ii) na segunda, os autores, moradores do bairro Nueva Granada, } \\
\text { afirmam que a água é fornecida de dois em dois dias, entre as seis e as doze } \\
\text { horas, e que não tem pressão suficiente para alcançar as casas mais altas do } \\
\text { bairro, apesar de todos pagarem pelo serviço. Após procurarem as empresas } \\
\text { responsáveis, não obtiveram resposta satisfatória. }\end{array}$ \\
\hline $\begin{array}{l}\text { FUNDAMENTOS JURÍDICOS } \\
\text { DO PEDIDO }\end{array}$ & $\begin{array}{l}\text { Os requerentes alegam violação aos direitos à vida, à saúde e à água. Os arts. } \\
365 \text { e } 366 \text { da Constituição colombiana }{ }^{40} \text { dispõem que o direito à água para } \\
\text { consumo humano deve ser garantido pelo Estado mediante a prestação de } \\
\text { serviço público de abastecimento de água. }\end{array}$ \\
\hline Pedido & $\begin{array}{l}\text { Os requerentes pediram que a Corte Constitucional ordenasse: (i) a prestação } \\
\text { imediata do serviço de água e de rede de esgoto (T-2.456.550); e (ii) medidas } \\
\text { direcionadas às autoridades competentes, no sentido de assegurar que todas } \\
\text { as casas do bairro Nueva Granada gozassem de um serviço de fornecimento de } \\
\text { água adequado (T- } 2.456 .678 \text { ). }\end{array}$ \\
\hline $\begin{array}{l}\text { EMENTA OU TRECHO } \\
\text { DESTACADO }\end{array}$ & $\begin{array}{l}\text { "A carência de água para consumo humano alegada nos casos é uma situação } \\
\text { que põe em risco a vida, a saúde e a dignidade das pessoas afetadas e, diante } \\
\text { dela, a ação de tutela é o mecanismo mais idôneo e eficaz para sua proteção. } \\
\text { Em razão disso, contrariamente à decisão adotada pelos juízes que resolveram } \\
\text { as tutelas, considera esta Sala que as ações que se examinam nos dois } \\
\text { expedientes são procedentes. Verificado o requisito de admissibilidade, } \\
\text { compete à Sala entrar no estudo de fundo de violação dos direitos invocados } \\
\text { nos casos submetidos à sua revisão de maneira independente. A entidade } \\
\text { recorrida violou o direito fundamental do recorrente à água, negando-se, em } \\
\text { diferentes oportunidades e com diferentes argumentos, a conectar o lugar de } \\
\text { residência ao sistema de água e esgoto da cidade. Por esse motivo, pôs em } \\
\text { perigo constante a dignidade humana do autor e sua família, pois os impediu } \\
\text { de gozarem das condições materiais mínimas de existência para realizarem } \\
\text { seus projetos vitais dentro da sociedade. Em atenção a isso, a Sala revogará a } \\
\text { decisão adotada pelo Juiz com Função de Conhecimento de Mendellín e, em } \\
\text { seu lugar, tutelará os direitos do peticionário à vida digna, à saúde e à água”" } \\
\text { (tradução livre). }\end{array}$ \\
\hline DECISÃO FINAL & $\begin{array}{l}\text { A Corte decidiu que o direito à água é um pré-requisito para que sejam } \\
\text { usufruídos outros direitos. Exemplo disso é o direito à educação. Segundo a } \\
\text { Corte, para garantir o funcionamento de uma escola, é necessário ter acesso a } \\
\text { serviços públicos como o abastecimento de água e esgoto. Ao final, a Corte } \\
\text { ordenou: (i) a implementação das instalações de água e esgoto na casa do } \\
\text { requerente (T-2.456.550); e (ii) uma série de medidas para que a comunidade }\end{array}$ \\
\hline
\end{tabular}

40 COLÔMBIA. Constituição Política da Colômbia, de 1991. Artigo 365. "Os serviços públicos são inerentes ao fim social do Estado. É dever do Estado assegurar sua prestação eficiente a todos os habitantes do território nacional. Os serviços públicos estarão submetidos ao regime jurídico fixado em lei, poderão ser prestados pelo Estado, direta ou indiretamente, por comunidades organizadas, ou por particulares. Em todo caso, o Estado manterá a regulação, o controle e a vigilância de ditos serviços. Se por razões de soberania ou de interesse social, o Estado, mediante lei aprovada pela maioria dos membros de uma e outra câmara, por iniciativa do Governo, decidir reservar-se determinadas atividades estratégicas ou serviços públicos, deverá indenizar prévia e plenamente as pessoas que em virtude de dita lei sejam privadas do exercício de uma atividade lícita. Artigo 366. O bem-estar geral e o melhoramento da qualidade de vida da população são finalidades sociais do Estado. Será objetivo fundamental de sua atividade a solução das necessidades insatisfeitas de saúde, de educação, de saneamento ambiental e de água potável. Para tais efeitos, nos programas e orçamentos da Nação e das entidades territoriais, o gasto público social terá prioridade sobre qualquer outra alocação" (livre tradução). Disponível em: $<$ http://www.corteconstitucional.gov.co/inicio/Constitucion\%20politica\%20de\%20Colombia.pdf >. Acesso em: 1‥dez.2017. 


\begin{tabular}{|l|l|}
\hline & $\begin{array}{l}\text { do bairro Nueva Granada passasse a ser atendida de maneira adequada (T- } \\
2.456 .678) .\end{array}$ \\
\hline VOTO VENCIDO & Não houve. \\
\hline $\begin{array}{l}\text { PORQUE O CASO É } \\
\text { PARADIGMÁTICO }\end{array}$ & $\begin{array}{l}\text { O caso é paradigmático pois trata da revisão de toda a jurisprudência da Corte } \\
\text { Constitucional sobre o direito à água. A Corte afirmou os diferentes aspectos } \\
\text { do direito fundamental à água, como a garantia mínima de que haverá (i) } \\
\text { disponibilidade, (ii) qualidade, (iii) acesso e (iv) não discriminação no } \\
\text { abastecimento de água. A Corte ressaltou o dever de uso dos melhores meios } \\
\text { disponíveis para que o direito à água seja uma realidade para os habitantes da } \\
\text { Colômbia. }{ }^{41}\end{array}$ \\
\hline LINK: http://www.corteconstitucional.gov.co/relatoria/2010/T-616-10.htm \\
\hline PALAVRAS-CHAVE & $\begin{array}{l}\text { DIREITO À ÁGUA - ACESSO À REDE DE ESGOTO - DIREITO À VIDA - DIREITO À } \\
\text { SAÚDE - DIGNIDADE HUMANA. }\end{array}$ \\
\hline
\end{tabular}

\begin{tabular}{|c|c|}
\hline 7. CASO & $\begin{array}{l}\text { SISTEMA UPAC DE FINANCIAMENTO DE MORADIAS } \\
\text { (DIREITO À MORADIA) }\end{array}$ \\
\hline CLASSE E NÚMERO & C-700/9942 \\
\hline ÓRGÃO JULGADOR & Colômbia, Corte Constitucional, Sala Plena. \\
\hline RELATOR & Jose Gregorio Hernandez Galindo \\
\hline REQUERENTE & Humberto de Jesús Longas Londoño \\
\hline REQUERIDO & Não informado. \\
\hline DATA DE JULGAMENTO & 16 de setembro de 1999 \\
\hline DATA DE PUBLICAÇÃO & Data de publicação não informada. \\
\hline FATOS & $\begin{array}{l}\text { Em 1972, o governo colombiano criou um sistema de financiamento de } \\
\text { imóveis a longo prazo, garantido por hipoteca e indexado a uma unidade } \\
\text { monetária denominada UPAC (unidade de poder de compra constante). } \\
\text { Inicialmente, o sistema funcionou bem: os empréstimos hipotecários de } \\
\text { longo prazo estavam vinculados às unidades do sistema UPAC, que, por sua } \\
\text { vez, estavam vinculadas à inflação. No início dos anos } 90 \text {, as unidades do } \\
\text { sistema UPAC também estavam vinculadas às taxas de juros vigentes na } \\
\text { economia em geral. No final da década de 1990, a Colômbia enfrentou uma } \\
\text { crise econômica e as taxas de juros aumentaram, gerando o aumento das } \\
\text { unidades do sistema UPAC. A situação foi agravada por uma taxa de } \\
\text { desemprego crescente, de modo que muitos proprietários não conseguiram } \\
\text { pagar suas dívidas. Ante à omissão do Banco Central, do Executivo e do } \\
\text { Legislativo em remediar a situação, grupos sociais se organizaram e } \\
\text { ajuizaram diversas ações no Judiciário entre os anos de } 1999 \text { e } 2000 .{ }^{43}\end{array}$ \\
\hline $\begin{array}{l}\text { FUNDAMENTOS JURÍDICOS } \\
\text { DO PEDIDO }\end{array}$ & $\begin{array}{l}\text { O autor alegou que os decretos presidenciais que modificaram o Sistema } \\
\text { UPAC são inconstitucionais, uma vez que só o Congresso da República teria } \\
\text { competência para dispor sobre a regulação do setor financeiro, sob pena de }\end{array}$ \\
\hline
\end{tabular}

41 Seleção de casos paradigmáticos da Corte colombiana. Disponível em: $<$ http://english.corteconstitucional.gov.co/sentences/T-616-2010.pdf>.Acesso em: 12.out.2017.

42 COLÔMBIA. Corte Constitucional da Colômbia. C-700/99. Sala Plena. Autor: Humberto de Jesús Longas Londoño. Relator: José Gregório Hernandez Galindo. Bogotá, 16 de setembro 1999. Disponível em: <http://www.corteconstitucional.gov.co/relatoria/1999/C-700-99.htm>. Acesso em: 7.dez.2017.

${ }^{43}$ ESPINOSA, Manuel José Cepeda; LANDAU, David. Colombian Constitutional Law: leading cases. New York: Oxford University Press, 2017. p. 154-155. FORERO, Efraín. Evolution of the mortgage system in colombia: from the UPAC to the UVR system. XLI Conferencia Interamericana para la Vivienda. Panamá: 2003. Disponível em: <http://www.housingfinance.org/uploads/Publicationsmanager/0403 Col.pdf $>$. Acesso em: 7.dez.2017.

Revista Publicum

Rio de Janeiro, v. 3, n. 2, 2017, p. 286-338

http://www.e-publicacoes.uerj.br/index.php/publicum

DOI: $10.12957 /$ publicum.2017.31883 


\begin{tabular}{|l|l|}
\hline & $\begin{array}{l}\text { violação dos arts.150, incisos } 13 \text { e } 19, \mathrm{~d}^{44} ; \text { art. } 189, \text { incisos } 24^{45} ; \text { art. } 334^{46} ; \\
\text { art. } 335^{47} ; \text { art. } 366^{48} \text { e art. } 373^{49} \text { da Constituição colombiana. }\end{array}$ \\
\hline PEDIDO & $\begin{array}{l}\text { O autor pediu que a Corte Constitucional declarasse a inconstitucionalidade } \\
\text { de artigos do Decreto Extraordinário } 663 \text { de } 1993 \text { (Estatuto Orgânico do } \\
\text { Sistema Financeiro) que regulavam o sistema UPAC. }\end{array}$ \\
\hline $\begin{array}{l}\text { EMENTA OU TRECHO } \\
\text { DESTACADO }\end{array}$ & $\begin{array}{l}\text { "Seguindo a reiterada jurisprudência da Corte e como os mencionados } \\
\text { decretos não estão produzindo na atualidade efeitos jurídicos, carece de }\end{array}$ \\
\hline
\end{tabular}

${ }^{44}$ COLÔMBIA. Constituição Política da Colômbia, de 1991. "Artigo 150. Compete ao Congresso fazer as leis. Por meio delas exerce as seguintes funções: [...] 13. Determinar a moeda legal, a conversibilidade e o alcance se seu poder liberatório e regular o sistema de pesos e medidas. [...] 19. Ditar as normas gerais e indicar os objetivos e critérios aos quais deve sujeitar-se o Governo para os seguintes efeitos: [...] d) Regular o mercado financeiro, mercado de ações, seguros e quaisquer outras relacionadas com o manejo, aproveitamento e inversão dosrecursos públicos" (livre tradução). Disponível em: $<$ http://www.corteconstitucional.gov.co/inicio/Constitucion\%20politica\%20de\%20Colombia.pdf >. Acesso em: 3.dez.2017.

45 COLÔMBIA. Constituição Política da Colômbia, de 1991. "Artigo 189. Compete ao Presidente da República como Chefe de Estado, Chefe de Governo e Suprema Autoridade Administrativa: [...]. 24. Exercer, de acordo com a lei, a fiscalização, vigilância e controle sobre as pessoas que realizem atividades financeiras, valores mobiliários, seguros e qualquer outra atividade relacionada com o manejo, aproveitamento ou inversão de recursos públicos. O mesmo se aplica às entidades cooperativas e as sociedades mercantis" (livre tradução). Disponível

em: $<$ http://www.corteconstitucional.gov.co/inicio/Constitucion\%20politica\%20de\%20Colombia.pdf $>$. Acesso em: 3.dez.2017.

${ }^{46}$ COLÔMBIA. Constituição Política da Colômbia, de 1991. "Artigo 334. A direção geral da economia estará a cargo do Estado. Esse intervirá, por mandato da lei, na exploração dos recursos naturais, no uso de solo, na produção, distribuição, utilização e consumo dos bens e em serviços públicos e privados, para racionalizar a economia com o fim de promover no plano nacional e territorial, em um marco de sustentabilidade fiscal, o melhoramento da qualidade de vida dos habitantes, distribuição equitativa das oportunidades, os benefícios do desenvolvimento e a preservação de um ambiente saudável. Este marco de sustentabilidade fiscal deve servir como um instrumento para alcançar de maneira progressiva os objetivos do Estado Social de Direito. Em qualquer caso, o gasto social público será prioritário" (livre tradução). Disponível em: $<$ http://www.corteconstitucional.gov.co/inicio/Constitucion\%20politica\%20de\%20Colombia.pdf>. Acesso em: 3.dez.2017.

${ }^{47}$ COLÔMBIA. Constituição Política da Colômbia, de 1991. "Artigo 335. As atividades financeiras, mercado de ações, seguros e qualquer outro relacionado ao manejo, aproveitamento e investimento dos recursos de captação referida na alínea d) do número 19 do artigo 150 são de interesse público e só poderão ser exercidos por prévia autorização do Estado, conforme a lei, a qual regulará a forma de intervenção do Governo nessas matérias e promoverá a democratização do crédito (livre tradução). Disponível em: $<$ http://www.corteconstitucional.gov.co/inicio/Constitucion\%20politica\%20de\%20Colombia.pdf>. Acesso em: 3.dez.2017.

48 COLÔMBIA. Constituição Política da Colômbia, de 1991. "Artigo 366. O bem-estar geral e o melhoramento da qualidade de vida da população são finalidades sociais do Estado. Será objetivo fundamental de sua atividade a solução das necessidades insatisfeitas de saúde, de educação, de saneamento ambiental e de água potável. Para tais efeitos, nos programas e orçamentos da Nação e das entidades territoriais, o gasto público social terá prioridade sobre qualquer outra alocação. (Livre tradução). Disponível em: $<$ http://www.corteconstitucional.gov.co/inicio/Constitucion\%20politica\%20de\%20Colombia.pdf>. Acesso em: 3.dez.2017.

${ }^{49}$ COLÔMBIA. Constituição Política da Colômbia, de 1991. "Artigo 373. O Estado, por intermédio do Banco de la República, velará pela manutenção do poder de compra da moeda. O Banco não poderá estabelecer cotas de crédito, ou conceder garantias em favor de particulares, salvo quando se trate de intermediação de crédito externo para sua colocação por meio de instituições de crédito, ou de suporte temporário de liquidez para os mesmos. As operações de financiamento a favor do Estado exigirão aprovação unânime do conselho de administração, a menos que seja uma operação de mercado aberto. O legislador, em nenhum caso, poderá ordenar cotas de crédito a favor do Estado ou de particulares" (livre tradução). Disponível em: $<$ http://www.corteconstitucional.gov.co/inicio/Constitucion\%20politica\%20de\%20Colombia.pdf>. Acesso em: 3.dez.2017. 


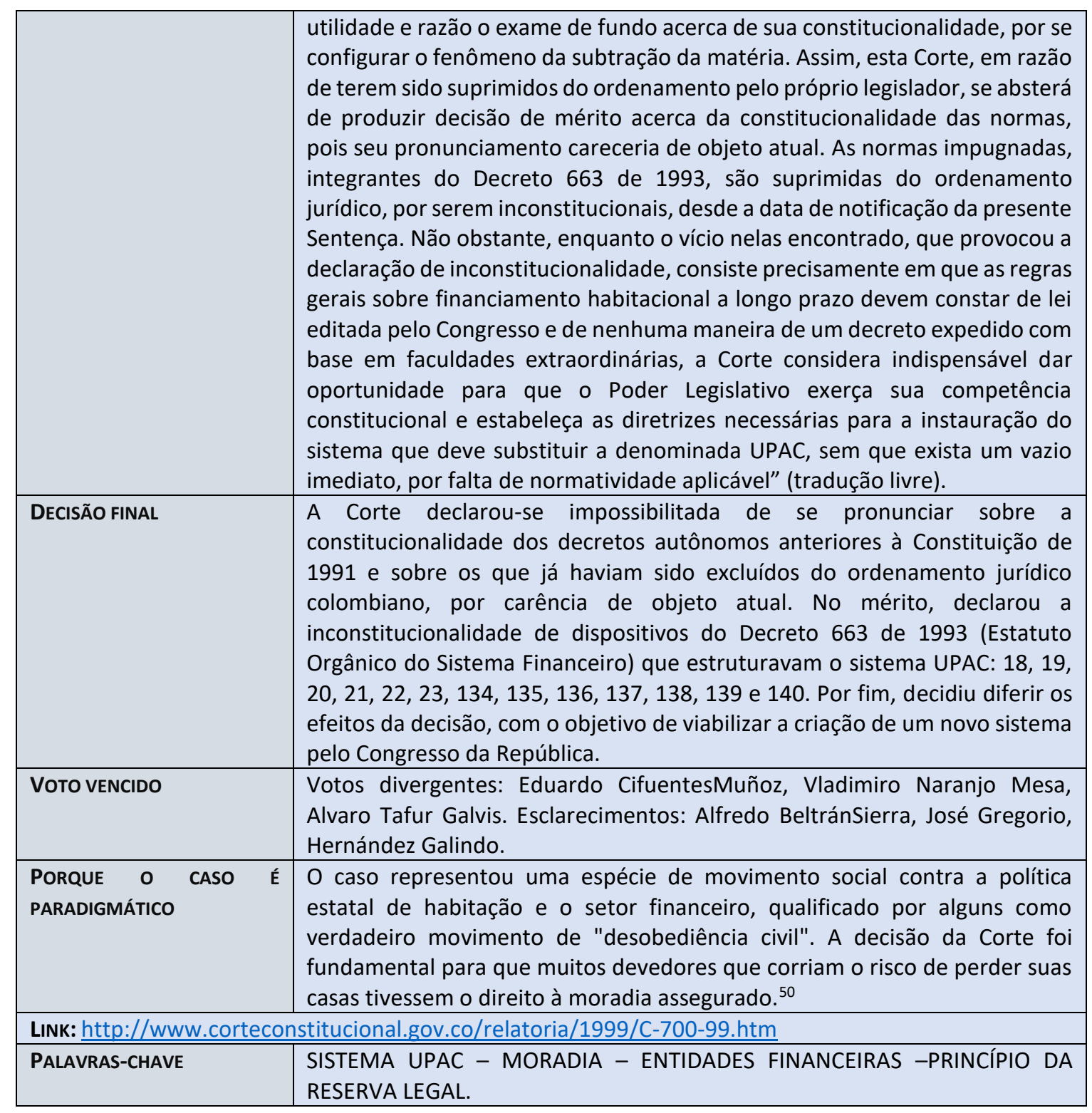

\title{
8. CASO
}

EDUCAÇÃO PARA CRIANÇAS COM NECESSIDADES ESPECIAIS

(DIREITO À EDUCAÇÃO)

\begin{abstract}
50 “Não há qualquer dúvida de que foram as sentenças do Tribunal que permitiram um certo alívio financeiro a um importante número de devedores e que, talvez em consequência disso, estes não perderam as suas casas. É igualmente certo que os devedores viram aumentadas as possibilidades de se defenderem face a eventuais ações de despejo. Finalmente, o litígio constitucional permitiu uma maior articulação entre os devedores e as suas associações, em uma espécie de movimento social de desobediência civil, de classe média, contra o sector financeiro e a política estatal de habitação. O movimento não foi, por óbvio, criado pela justiça constitucional; porém, esta propiciou o seu dinamismo quando conferiu não só visibilidade política aos devedores e às suas associações como modificou o sentido das suas intervenções; já não se tratava de queixas de devedores isolados, mas sim de uma tomada de posição coletiva, com o aval do Tribunal, que colocou em questão a política estatal de habitação e o comportamento das entidades financeiras" (livre tradução). GARCÍA, Mauricio; UPRIMNY, Rodrigo. Corte Constitucional y emancipación social em Colombia. Comunicação apresentada no simpósio A reinvenção da Emancipação Social. Coimbra: Centro de Estudos Sociais/Faculdade de economia da Universidade de Coimbra, 2000.
\end{abstract}

Revista Publicum

Rio de Janeiro, v. 3, n. 2, 2017, p. 286-338

http://www.e-publicacoes.uerj.br/index.php/publicum

DOI: 10.12957/publicum.2017.31883 


\begin{tabular}{|l|l|}
\hline CLASSE E NÚMERO & T-523/16 ${ }^{51}$ \\
\hline ÓRGÃO JULGADOR & Colômbia, Corte Constitucional, Quinta Sala de Revisão \\
\hline RELATOR & Gloria Stella Ortiz Delgado \\
\hline REQUERENTE & Margarita María Atehortua Ortega \\
\hline REQUERIDO & Ministério de Educación-Dirección de Cobertura e Equidad \\
\hline DATA DE JULGAMENTO & 21 de setembro de 2016 \\
\hline DATA DE PUBLICAÇÃo & Data de publicação não informada. \\
\hline FATOS & $\begin{array}{l}\text { A autora é mãe de criança que tem transtorno de linguagem misto, déficit de } \\
\text { atenção e hiperatividade. Desde 2003, seu filho menor e os estudantes do } \\
\text { Colégio Integrado Los Laureles e do Gimnasio Campestre El Tesoro, do } \\
\text { Município de Envigado, eram amparados por serviços educativos regulares } \\
\text { com enfoque em crianças e jovens com necessidades especiais e excepcionais. } \\
\text { No entanto, a Secretaria de Educação do município de Envigado informou aos } \\
\text { encarregados da educação dos alunos que os colégios não atendiam aos } \\
\text { percentuais mínimos para serem habilitados à contratação pelo Estado, nos } \\
\text { termos do Decreto 1.851, de 2015 }{ }^{52} \text { Em consequência, as crianças } \\
\text { matriculadas em escolas particulares contratadas pelo Estado seriam } \\
\text { direcionadas a escolas públicas com apoios pedagógicos para atender suas } \\
\text { necessidades individuais. }\end{array}$ \\
\hline $\begin{array}{l}\text { A requerente apresentou a ação de tutela para solicitar a proteção dos direitos } \\
\text { à educação, à dignidade, à integridade pessoal e ao bem-estar de seus } \\
\text { representados. A educação é um direito e um serviço público com função social } \\
\text { (art. 67 da Constituição) que deve ser orientado em conformidade com o } \\
\text { desenvolvimento da personalidade humana e de sua dignidade (art. 13 do } \\
\text { Pacto Internacional de Direitos Econômicos, Sociais e Culturais } 5 \text {, ratificado }\end{array}$ \\
\hline
\end{tabular}

51 COLÔMBIA. Corte Constitucional da Colômbia. T-523/16. Quinta Sala de Revisão. Autor: Margarita MaríaAtehortua Ortega. Réu: Ministério de Educación-Dirección de Cobertura e Equidad. Relatora: Gloria Stella Ortiz Delgado. Bogotá, 21 de setembro de 2016. Disponível em: <http://www.corteconstitucional.gov.co/relatoria/2016/t-523-16.htm>. Acesso em: 7.dez.2017.

52 COLÔMBIA. Decreto 1.851, de 16 set. 2015. Disponível em: <http://www.mineducacion.gov.co/1759/w3article-353928.html>. Acesso em: 1‥dez.2017.

53 COLÔMBIA, Constituição Política da Colômbia, de 1991. "Artigo 67. A educação é um direito da pessoa e um serviço público que tem uma função social; com ela se busca o conhecimento, a ciência, a técnica, e os demais bens e valores da cultura. A educação levará o colombiano ao respeito aos direitos humanos, à paz e à democracia; e à prática do trabalho e recreação, para o melhoramento cultural, científico, tecnológico e para a proteção do ambiente. O Estado, a sociedade e a família são responsáveis pela educação, que será obrigatória entre os cinco e os quinze anos de idade, e que compreenderá, como mínimo, um ano de préescola e nove de educação básica. A educação será gratuita nas instituições do Estado, sem prejuízo da cobrança de taxas acadêmicas a quem puder suportá-las. É dever do Estado regular e exercer a suprema inspeção e vigilância da educação com o fim de velar por sua qualidade, pelo cumprimento de seus fins e pela melhor formação moral, intelectual e física dos educandos; garantir a adequada cobertura do serviço e assegurar aos menores as condições necessárias para seu acesso e permanência no sistema educativo. A Nação e as entidades territoriais participarão na direção, financiamento e administração dos serviços educativos estatais, nos termos da Constituição e da lei" (livre tradução). Disponível em: $<$ http://www.corteconstitucional.gov.co/inicio/Constitucion\%20politica\%20de\%20Colombia.pdf $>$. Acesso em: 1‥dez.2017.

54 ORGANIZAÇÃO DAS NAÇÕES UNIDAS (ONU). Assembleia Geral. Pacto Internacional de Direitos Econômicos, Sociais e Culturais, de 16 dez. 1966. "Artigo 13. 1. Os Estados Partes do presente Pacto reconhecem o direito de toda pessoa à educação. Concordam em que a educação deverá visar ao pleno desenvolvimento da personalidade humana e do sentido de sua dignidade e fortalecer o respeito pelos direitos humanos e liberdades fundamentais. Concordam ainda em que a educação deverá capacitar todas as pessoas a participar efetivamente de uma sociedade livre, favorecer a compreensão, a tolerância e a amizade entre todas as nações e entre todos os grupos raciais, étnicos ou religiosos e promover as atividades das Nações Unidas em

Revista Publicum

Rio de Janeiro, v. 3, n. 2, 2017, p. 286-338

http://www.e-publicacoes.uerj.br/index.php/publicum

DOI: 10.12957/publicum.2017.31883 
pela Colômbia e incorporado no bloco de constitucionalidade, e art. 26 da Declaração Universal dos Direitos Humanos). ${ }^{55} \mathrm{O}$ direito à educação para pessoas especiais está previsto no ordenamento constitucional colombiano nos arts. 13,44 e $68,{ }^{56}$ além das previsões da Convenção Internacional sobre

prol da manutenção da paz. 2. Os Estados Partes do presente Pacto reconhecem que, com o objetivo de assegurar o pleno exercício desse direito: a) A educação primária deverá ser obrigatória e acessível gratuitamente a todos; b) A educação secundária em suas diferentes formas, inclusive a educação secundária técnica e profissional, deverá ser generalizada e tornar-se acessível a todos, por todos os meios apropriados e, principalmente, pela implementação progressiva do ensino gratuito; c) A educação de nível superior deverá igualmente tornar-se acessível a todos, com base na capacidade de cada um, por todos os meios apropriados e, principalmente, pela implementação progressiva do ensino gratuito; d) Dever-se-á fomentar e intensificar, na medida do possível, a educação de base para aquelas pessoas que não receberam educação primária ou não concluíram o ciclo completo de educação primária; e) Será preciso prosseguir ativamente no desenvolvimento de uma rede escolar em todos os níveis de ensino, implementar um sistema adequado de bolsas de estudo e melhorar continuamente as condições materiais do corpo docente. 1. Os Estados Partes do presente Pacto comprometem-se a respeitar a liberdade dos pais e, quando for o caso, dos tutores legais de escolher para seus filhos escolas distintas daquelas criadas pelas autoridades públicas, sempre que atendam aos padrões mínimos de ensino prescritos ou aprovados pelo Estado, e de fazer com que seus filhos venham a receber educação religiosa ou moral que esteja de acordo com suas próprias convicções. 2. Nenhuma das disposições do presente artigo poderá ser interpretada no sentido de restringir a liberdade de indivíduos e de entidades de criar e dirigir instituições de ensino, desde que respeitados os princípios enunciados no parágrafo 1 do presente artigo e que essas instituições observem os padrões mínimos prescritos pelo Estado". Disponível em: <http://www.planalto.gov.br/ccivil 03/decreto/19901994/d0591.htm>. Acesso em: 10.dez.2017.

55 ORGANIZAÇÃO DAS NAÇÕES UNIDAS (ONU). Assembleia Geral. Declaração Universal dos Direitos Humanos, adotada e proclamada pela Resolução 217 A (III), de 10 dez. 1948. "Artigo 26. 1. Todo ser humano tem direito à instrução. $A$ instrução será gratuita, pelo menos nos graus elementares e fundamentais. A instrução elementar será obrigatória. A instrução técnico-profissional será acessível a todos, bem como a instrução superior, esta baseada no mérito. 2. A instrução será orientada no sentido do pleno desenvolvimento da personalidade humana e do fortalecimento do respeito pelos direitos humanos e pelas liberdades fundamentais. A instrução promoverá a compreensão, a tolerância e a amizade entre todas as nações e grupos raciais ou religiosos, e coadjuvará as atividades das Nações Unidas em prol da manutenção da paz. 3. Os pais têm prioridade de direito na escolha do gênero de instrução que será ministrada a seus filhos". Disponível em: <http://unesdoc.unesco.org/images/0013/001394/139423por.pdf>. Acesso em: 10.dez.2017.

${ }^{56}$ COLÔMBIA. Constituição Política da Colômbia, de 1991. "Artigo 13. Todas as pessoas nascem livres e iguais perante a lei, receberão a mesma proteção e tratamento das autoridades e gozarão dos mesmos direitos, liberdades e oportunidades sem nenhuma discriminação por razões de sexo, raça, origem nacional ou familiar, língua, religião, opinião política ou filosófica. O Estado promoverá as condições para que a igualdade seja real e efetiva e adotará medidas em favor de grupos discriminados ou marginalizados. O Estado protegerá especialmente aquelas pessoas que, por sua condição econômica, física ou mental se encontrem em circunstância de debilidade manifesta e sancionará os abusos ou maus tratos que contra elas se cometam. Artigo 44. São direitos das crianças: a vida, a integridade física, a saúde e a seguridade social, a alimentação equilibrada, seu nome e nacionalidade, ter uma família e não ser dela separada, o cuidado e o amor, a educação e a cultura, a recreação e a livre expressão de sua opinião. Serão protegidas contra toda forma de abandono, violência física ou moral, sequestro, venda, abuso sexual, exploração laboral ou econômica e trabalhos perigosos. Gozarão também dos demais direitos consagrados na Constituição, nas leis e nos tratados internacionais ratificados pela Colômbia". "Artigo 68. Os particulares poderão fundar estabelecimentos educativos. A lei estabelecerá as condições para sua criação e gestão. A comunidade educativa participará da direção das instituições de educação. O ensino estará a cargo de pessoas de reconhecida idoneidade ética e pedagógica. A Lei garantirá a profissionalização e dignificação da atividade docente. Os pais de família terão direito de escolher o tipo de educação para seus filhos menores. Nos estabelecimentos do Estado nenhuma pessoa poderá ser obrigada a receber educação religiosa. Os integrantes dos grupos étnicos terão direito a uma formação que respeite e desenvolva sua identidade cultural. A erradicação do analfabetismo e a educação de pessoas com limitações físicas ou mentais, ou com capacidades excepcionais, são obrigações especiais do Estado" (livre tradução). Disponível em:

Revista Publicum

Rio de Janeiro, v. 3, n. 2, 2017, p. 286-338

http://www.e-publicacoes.uerj.br/index.php/publicum

DOI: 10.12957/publicum.2017.31883 
os Direitos da Criança (arts. 28 e 29$)^{57}$, da Convenção Interamericana para Eliminação de Todas as Formas de Discriminação contra as Pessoas Portadoras de Deficiência ${ }^{58}$ e da Convenção Internacional sobre Direitos das Pessoas com Deficiência (art. 24) ${ }^{59}$.

$<$ http://www.corteconstitucional.gov.co/inicio/Constitucion\%20politica\%20de\%20Colombia.pdf $>$. Acesso em: 1‥dez.2017.

57 ORGANIZAÇÃO DAS NAÇÕES UNIDAS (ONU). Assembleia Geral. Convenção sobre os Direitos da Criança, de 20 nov. 1989. "Artigo 28.1 - Os Estados Partes reconhecem o direito da criança à educação e, a fim de que ela possa exercer progressivamente e em igualdade de condições esse direito, deverão especialmente: a) tornar o ensino primário obrigatório e disponível gratuitamente para todos; b) estimular o desenvolvimento do ensino secundário em suas diferentes formas, inclusive o ensino geral e profissionalizante, tornando-o disponível e acessível a todas as crianças, e adotar medidas apropriadas tais como a implantação do ensino gratuito e a concessão de assistência financeira em caso de necessidade; c) tornar o ensino superior acessível a todos com base na capacidade e por todos os meios adequados; d) tornar a informação e a orientação educacionais e profissionais disponíveis e acessíveis a todas as crianças; e) adotar medidas para estimular a frequência regular às escolas e a redução do índice de evasão escolar. 2 - Os Estados Partes adotarão todas as medidas necessárias para assegurar que a disciplina escolar seja ministrada de maneira compatível com a dignidade humana e em conformidade com a presente Convenção. 3 - Os Estados Partes promoverão e estimularão a cooperação internacional em questões relativas à educação, especialmente visando contribuir para a eliminação da ignorância e do analfabetismo no mundo e facilitar o acesso aos conhecimentos científicos e técnicos e aos métodos modernos de ensino. A esse respeito, será dada atenção especial às necessidades dos países em desenvolvimento". "Artigo 29. 1 - Os Estados Partes reconhecem que a educação da criança deverá estar orientada no sentido de: a) desenvolver a personalidade, as aptidões e a capacidade mental e física da criança em todo seu potencial; b) imbuir na criança o respeito aos direitos humanos e às liberdades fundamentais, bem como aos princípios consagrados na Carta das Nações Unidas; c) imbuir na criança o respeito aos seus pais, à sua própria identidade cultural, ao seu idioma e seus valores, aos valores nacionais do país que reside, aos do eventual país de origem, e aos das civilizações diferentes da sua; d) preparar a criança para assumir uma vida responsável numa sociedade livre, com espírito de compreensão, paz, tolerância, igualdade de sexos e amizade entre todos os povos, grupos étnicos, nacionais e religiosos, e pessoas de origem indígenas; e) imbuir na criança o respeito ao meio ambiente. 2 - Nada do disposto no presente Artigo ou no Artigo 28 será interpretado de modo a restringir a liberdade dos indivíduos ou das entidades de criar e dirigir instituições de ensino, desde que sejam respeitados os princípios enunciados no parágrafo 1 do presente Artigo e que a educação ministrada em tais instituições esteja acorde com os padrões mínimos pelo Estado". Disponível em: $<$ https://www.unicef.org/brazil/pt/resources 10127.htm>. Acesso em: 1‥dez.2017.

58 ORGANIZAÇÃO DOS ESTADOS AMERICANOS (OEA). Comissão Interamericana de Direitos Humanos. Convenção Interamericana para Eliminação de Todas as Formas de Discriminação contra as Pessoas Portadoras de Deficiência, de 7 jun. 1999. Disponível em: <http://www.cidh.oas.org/basicos/portugues/o.Convencao.Personas.Portadoras.de.Deficiencia.htm>.

Acesso em: 10.dez.2017.

59 ORGANIZAÇÃO DAS NAÇÕES UNIDAS (ONU). Assembleia Geral. Convenção sobre Direitos das Pessoas com Deficiência, de 13 dez. 2006. "Artigo 24. Educação. 1. Os Estados Partes reconhecem o direito das pessoas com deficiência à educação. Para efetivar esse direito sem discriminação e com base na igualdade de oportunidades, os Estados Partes assegurarão um sistema educacional inclusivo em todos os níveis, bem como o aprendizado ao longo de toda a vida, com os seguintes objetivos: a) O pleno desenvolvimento do potencial humano e do senso de dignidade e autoestima, além do fortalecimento do respeito pelos direitos humanos, pelas liberdades fundamentais e pela diversidade humana; b) O máximo desenvolvimento possível da personalidade e dos talentos e da criatividade das pessoas com deficiência, assim como de suas habilidades físicas e intelectuais; c) A participação efetiva das pessoas com deficiência em uma sociedade livre. 2. Para a realização desse direito, os Estados Partes assegurarão que: a) As pessoas com deficiência não sejam excluídas do sistema educacional geral sob alegação de deficiência e que as crianças com deficiência não sejam excluídas do ensino primário gratuito e compulsório ou do ensino secundário, sob alegação de deficiência; b) As pessoas com deficiência possam ter acesso ao ensino primário inclusivo, de qualidade e gratuito, e ao ensino secundário, em igualdade de condições com as demais pessoas na comunidade em que vivem; c) Adaptações razoáveis de acordo com as necessidades individuais sejam providenciadas; d) As pessoas com deficiência recebam o apoio necessário, no âmbito do sistema educacional geral, com vistas a facilitar sua

Revista Publicum

Rio de Janeiro, v. 3, n. 2, 2017, p. 286-338

http://www.e-publicacoes.uerj.br/index.php/publicum

DOI: $10.12957 /$ publicum.2017.31883 


\begin{tabular}{|c|c|}
\hline PEDIDO & $\begin{array}{l}\text { Pediu-se que fosse feita classificação justa para os colégios fornecedores de } \\
\text { serviços de educação voltada para pessoas com necessidades especiais e que } \\
\text { fossem tomadas medidas de gestão para ampliar o atendimento educacional } \\
\text { a essas pessoas. }\end{array}$ \\
\hline $\begin{array}{l}\text { EMENTA OU TRECHO } \\
\text { DESTACADO }\end{array}$ & $\begin{array}{l}\text { "A legislação nacional trouxe diferentes critérios para assegurar que a } \\
\text { educação seja de qualidade, os quais fazem referência à organização do plano } \\
\text { de ensino, à segurança dos colégios, levando em consideração que sua } \\
\text { avaliação deve reconhecer as desigualdades existentes e atuar para assegurar } \\
\text { a equidade. Ademais, a principal ferramenta de avaliação são as provas do } \\
\text { Estado" (tradução livre). }\end{array}$ \\
\hline DECISÃO FINAL & $\begin{array}{l}\text { A Corte decidiu que, em um prazo máximo seis meses, o Ministério da } \\
\text { Educação deveria criar um método de avaliação de planos educacionais que } \\
\text { fosse inclusivo para as pessoas com necessidades especiais. Ainda, determinou } \\
\text { que o Ministério da Educação implementasse uma estratégia de diálogo mais } \\
\text { eficaz entre os colégios, sociedade, ONGs, instituições do Estado, profissionais } \\
\text { da área, pessoas com deficiência e suas famílias, para que sejam informados a } \\
\text { respeito do modelo de educação inclusiva. }\end{array}$ \\
\hline VOTO VENCIDO & Não houve. \\
\hline $\begin{array}{l}\text { PORQUE O CASO É } \\
\text { PARADIGMÁTICO }\end{array}$ & $\begin{array}{l}\text { O caso é paradigmático porque enfrentou o modelo de avaliação das } \\
\text { instituições educacionais capazes de contratar com as entidades territoriais, } \\
\text { com o objetivo de proteger o direito à educação para as pessoas com } \\
\text { necessidades especiais. Além disso, previu o acompanhamento da ordem pelo } \\
\text { juiz de primeira instância em relação ao resultado da gestão do Ministério da } \\
\text { Educação. }\end{array}$ \\
\hline \multicolumn{2}{|c|}{ LINK: http://www.corteconstitucional.gov.co/relatoria/2016/T-523-16.htm } \\
\hline PALAVRAS-CHAVE & $\begin{array}{l}\text { EDUCAÇÃO INCLUSIVA }- \text { CRIANÇA }- \text { NECESSIDADES } \\
\text { DISPONIBILIDADE - ACESSIBILIDADE -AVALIAÇÃO. }\end{array}$ \\
\hline
\end{tabular}

\section{CASO}

DIREITO AO TRABALHO DE PROFISSIONAIS DO SEXO

(DIREITO AO TRABALHO, PROTEÇÃo À MATERNIDADE E À MULHER CHEFE DE FAMÍLIA)

efetiva educação; e) Medidas de apoio individualizadas e efetivas sejam adotadas em ambientes que maximizem o desenvolvimento acadêmico e social, de acordo com a meta de inclusão plena. 3. Os Estados Partes assegurarão às pessoas com deficiência a possibilidade de adquirir as competências práticas e sociais necessárias de modo a facilitar às pessoas com deficiência sua plena e igual participação no sistema de ensino e na vida em comunidade. Para tanto, os Estados Partes tomarão medidas apropriadas, incluindo: a) Facilitação do aprendizado do Braille, escrita alternativa, modos, meios e formatos de comunicação aumentativa e alternativa, e habilidades de orientação e mobilidade, além de facilitação do apoio e aconselhamento de pares; b) Facilitação do aprendizado da língua de sinais e promoção da identidade linguística da comunidade surda; c) Garantia de que a educação de pessoas, em particular crianças cegas e surdas, seja ministrada nas línguas e nos modos e meios de comunicação mais adequados ao indivíduo e em ambientes que favoreçam ao máximo seu desenvolvimento acadêmico e social. 4. A fim de contribuir para o exercício desse direito, os Estados Partes tomarão medidas apropriadas para empregar professores, inclusive professores com deficiência, habilitados para o ensino da língua de sinais e/ou do Braille, e para capacitar profissionais e equipes atuantes em todos os níveis de ensino. Essa capacitação incorporará a conscientização da deficiência e a utilização de modos, meios e formatos apropriados de comunicação aumentativa e alternativa, e técnicas e materiais pedagógicos, como apoios para pessoas com deficiência. 5. Os Estados Partes assegurarão que as pessoas com deficiência possam ter acesso ao ensino superior em geral, treinamento profissional de acordo com sua vocação, educação para adultos e formação continuada, sem discriminação e em igualdade de condições. Para tanto, os Estados Partes assegurarão a provisão de adaptações razoáveis para pessoas com deficiência". Disponível em: $<$ http://www.pessoacomdeficiencia.gov.br/app/sites/default/files/publicacoes/convencaopessoascomdefici encia.pdf>. Acesso em: 1‥dez.2017.

Revista Publicum

Rio de Janeiro, v. 3, n. 2, 2017, p. 286-338

http://www.e-publicacoes.uerj.br/index.php/publicum

DOI: $10.12957 /$ publicum.2017.31883 


\begin{tabular}{|c|c|}
\hline CLASSE E NÚMERO & T-629/10 \\
\hline ÓRGÃO JULGADOR & Colômbia, Corte Constitucional da Colômbia, Sala Plena \\
\hline RELATOR & Juan Carlos Henao Pérez \\
\hline REQUERENTE & Lais $^{61}$ \\
\hline REQUERIDO & Bar Discoteca Pandemo, de propriedade de Zoto \\
\hline DATA DE JULGAMENTO & 13 de agosto de 2010 \\
\hline DATA DE PUBLICAÇÃO & Data de publicação não informada. \\
\hline FATOS & $\begin{array}{l}\text { A autora afirma que trabalhava como prostituta no bar requerido, mediante } \\
\text { contrato verbal e indefinido, desde } 9 \text { de fevereiro de } 2008 \text {. Em } 1^{\circ} \text { de dezembro } \\
\text { do mesmo ano, informou ao seu empregador que estava grávida, quando foi } \\
\text { orientada a seguir trabalhando como de costume. Em } 17 \text { de janeiro de } 2009 \text {, } \\
\text { informou ao empregador que sua gravidez era de risco, o que fez com que ele } \\
\text { a colocasse como administradora do bar. Dias depois, em } 22 \text { de fevereiro, sua } \\
\text { função foi repassada para outra pessoa e, então, em } 26 \text { de março, foi } \\
\text { despedida sob a alegação de que a gravidez a impediria de trabalhar no local. } \\
\text { A autora se dirigiu ao Ministério da Proteção Social, onde foi orientada a } \\
\text { elaborar uma carta solicitando informações sobre os motivos de sua demissão. } \\
\text { A carta foi apresentada, mas não foi respondida pelo empregador. A autora } \\
\text { pediu assessoria, ainda, à Defensoria do Povo, que, de igual modo, requereu } \\
\text { informações sobre as causas da demissão ao empregador e que também ficou } \\
\text { sem resposta. }\end{array}$ \\
\hline $\begin{array}{l}\text { FUNDAMENTOS JURÍDICOS } \\
\text { DO PEDIDO }\end{array}$ & $\begin{array}{l}\text { A autora fundamentou a demanda no art.13 da Constituição (princípio da } \\
\text { igualdade }{ }^{62} \text {, bem como nos direitos fundamentais ao trabalho, à seguridade } \\
\text { social, à igualdade, ao devido processo, à saúde, à dignidade, à proteção da } \\
\text { mulher grávida, ao mínimo vital e à vida de quem estava por nascer. }\end{array}$ \\
\hline PEDIDO & $\begin{array}{l}\text { A autora pediu que o representante legal do Bar Pandemo fosse condenado a } \\
\text { reintegrá-la no mesmo cargo, com as mesmas condições de trabalho e com a } \\
\text { remuneração e os direitos não pagos desde a data da dispensa. }\end{array}$ \\
\hline $\begin{array}{l}\text { EMENTA OU TRECHO } \\
\text { DESTACADO }\end{array}$ & $\begin{array}{l}\text { "O que se observa é um reconhecimento do tratamento especial que deve ser } \\
\text { dado no Estado Colombiano à mulher como tal, mas particularmente à mãe e }\end{array}$ \\
\hline
\end{tabular}

60 COLÔMBIA. Corte Constitucional da Colômbia. T-629/10. Sala Plena. Autor: Lais. Réu: Bar Discoteca Pandemo. Relator: Juan Carlos Henao Pérez. Bogotá, 13 de agosto de 2010. Disponível em: <http://www.corteconstitucional.gov.co/RELATORIA/2010/T-629-10.htm\# ftnref1>. Acesso em: 7.dez.2017. ${ }^{61} \mathrm{~A}$ Corte colombiana, com o propósito de proteger o direito à intimidade e ao bom nome, em respeito ao artigo 15 da Constituição, preservou o nome da autora, do estabelecimento comercial, de seu proprietário e das testemunhas do processo, utilizando os nomes que constam da decisão, escolhidos pela Corte para identificar as pessoas do processo. COLÔMBIA. Constituição Política da Colômbia, de 1991. "Artigo 15. Todas as pessoas têm direito a sua intimidade pessoal e familiar e a seu bom nome, e o Estado deve respeitá-los e fazer com que sejam respeitados. De igual modo, têm direito a conhecer, atualizar e retificar as informações obtidas sobre elas em bancos de dados e em arquivos de entidades públicas e privadas" (livre tradução). Disponível

em: $<$ http://www.corteconstitucional.gov.co/inicio/Constitucion\%20politica\%20de\%20Colombia.pdf>. Acesso em: 1‥dez.2017.

${ }^{62}$ COLÔMBIA. Constituição Política da Colômbia, de 1991. "Artigo 13. Todas as pessoas nascem livres e iguais perante a lei, receberão a mesma proteção e tratamento das autoridades e gozarão dos mesmos direitos, liberdades e oportunidades sem nenhuma discriminação por razões de sexo, raça, origem nacional ou familiar, língua, religião, opinião política ou filosófica. O Estado promoverá as condições para que a igualdade seja real e efetiva e adotará medidas em favor de grupos discriminados ou marginalizados. O Estado protegerá especialmente aquelas pessoas que por sua condição econômica, física ou mental se encontrem em circunstância de debilidade manifesta e sancionará os abusos ou maus-tratos que contra elas se cometam" (livre tradução). Disponível em: <http://www.corteconstitucional.gov.co/inicio/Constitucion\%20politica\%20de\%20Colombia.pdf >. Acesso em: 1‥dez.2017. 


\begin{tabular}{|c|c|}
\hline & $\begin{array}{l}\text { chefe de família, uma vez que o apoio que deve ser recebido do Estado não é } \\
\text { apenas um princípio constitucional de igualdade comtemplado no art. } 13 \text { da } \\
\text { Constituição, mas possui manifestação concreta nos arts. } 43 \text { e } 44 \text { do CP, como } \\
\text { comandos constitucionais de prestação para o Estado ou para os associados, } \\
\text { como direitos sociais fundamentais para seus titulares. Por isso, tal condição } \\
\text { subjetiva tem servido para reforçar seus direitos laborais em relação aos } \\
\text { demais trabalhadores, no sentido de limitar o empregador em seu poder de } \\
\text { disponibilidade da trabalhadora e incrementar pari passu a estabilidade como } \\
\text { uma forma de proteção efetiva dos bens constitucionais com ela relacionados: } \\
\text { direitos da mulher, direito à não discriminação, direitos das crianças, direitos } \\
\text { da família [...]." (tradução livre). }\end{array}$ \\
\hline DECISÃO FINAL & $\begin{array}{l}\text { A Corte decidiu reconhecer os direitos fundamentais pleiteados para } \\
\text { determinar ao proprietário do Bar que pagasse à requerente os direitos } \\
\text { trabalhistas vencidos, bem como indenizaçãopelos danos decorrentes da } \\
\text { demissão. Ainda, ordenou que a Defensoria Pública monitorasse a decisão, } \\
\text { com o fim de garantir a efetividade dos direitos protegidos. Por fim, } \\
\text { aconselhou as autoridades distritais, administrativas e de polícia do Distrito da } \\
\text { Capital, bem como o Ministério da Proteção Social, sobre a necessidade de } \\
\text { cumprirem seu papel de forma a proteger efetivamente os direitos das pessoas } \\
\text { que exercem referida atividade. }\end{array}$ \\
\hline VOTO VENCIDO & Não houve. \\
\hline $\begin{array}{l}\text { PORQUE O CASO É } \\
\text { PARADIGMÁTICO }\end{array}$ & $\begin{array}{l}\text { A decisão assegurou a proteção dos direitos trabalhistas de profissionais do } \\
\text { sexo, assegurando-lhes os mesmos direitos a que fazem jus todos os outros } \\
\text { trabalhadores. }{ }^{63}\end{array}$ \\
\hline \multicolumn{2}{|c|}{ LINK: http://www.corteconstitucional.gov.co/relatoria/2010/T-629-10.htm } \\
\hline PALAVRAS-CHAVE & $\begin{array}{l}\text { PROFISSIONAIS DO SEXO - GRAVIDEZ - MULHER CHEFE DE FAMÍLIA - DIREITOS } \\
\text { LABORAIS -SAÚDE - SEGURIDADE SOCIAL - ESTABILIDADE. }\end{array}$ \\
\hline
\end{tabular}




\section{Casoteca do Equador ${ }^{64}$}

Coordenação Geral

Patrícia Perrone Campos Mello ${ }^{65}$

Alessia Barroso Lima Brito Champos Chevitarese ${ }^{66}$

Coordenação do Grupo

Vanessa Wendhausen Cavallazzi ${ }^{67}$

Eduardo Lourenço Gregório Júnior ${ }^{68}$

Pesquisadores

Alessia Chevitarese

Isac de Lima Campos ${ }^{69}$

Eduardo Lourenço Gregório Júnior

Patrícia Perrone Campos Mello

Raony de Brito Soares ${ }^{70}$

Vanessa Wendhausen Cavallazzi

Pesquisador Revisor

Felipe Meneses Graça

Membro Executivo

Naiara Ferreira Martins ${ }^{71}$

64 O presente trabalho foi produzido pelo grupo de pesquisa CORTES CONSTITUCIONAIS E DEMOCRACIA, vinculado ao Programa de Mestrado e Doutorado do Centro Universitário de Brasília - UNICEUB. Coordenadoras: Patrícia Perrone Campos Mello e Alessia Barroso Lima Brito Campos Chevitarese. Informações disponíveis em: $<$ https://www.uniceub.br/cursos/direito-e-relacoes-internacionais/mestrado-e-doutorado/direito/gruposde-pesquisa.aspx\#c>.

65 Professora do Programa de Mestrado e Doutorado e da Graduação do Centro Universitário de Brasília UNICEUB. Doutora e Mestre em Direito Público (UERJ). Assessora de Ministro do Supremo Tribunal Federal. Procuradora do Estado do Rio de Janeiro.

66 Professora da Pós-Graduação (lato sensu) e da Graduação do Centro Universitário de Brasília - UNICEUB. Professora da Clínica de Direitos Humanos do UNICEUB. Doutora e Mestre pelo Centro Universitário de Brasília - UNICEUB. Membro da Comissão de Assuntos Constitucionais da OAB/DF.

67 Promotora de Justiça do Ministério Público do Estado de Santa Catarina. Mestranda pelo Programa de Mestrado e Doutorado em Direito do Centro Universitário de Brasília - UNICEUB. Membro Auxiliar do Conselho Nacional do Ministério Público (CNMP).

${ }^{68}$ Advogado. Mestrando do Programa de Mestrado e Doutorado em Direito pelo Centro Universitário de Brasília - UNICEUB. Master of Laws (LLM) em Direito Tributário pelo IBMEC. Membro das Comissões de Assuntos e Reforma Tributária e de Apoio ao Advogado Iniciante da OAB/DF. Sócio do Escritório Maneira Advogados.

${ }^{69}$ Graduando em Direito pelo Centro Universitário de Brasília - UNICEUB.

70 Graduando em Direito pelo Centro Universitário de Brasília - UNICEUB.

${ }^{71}$ Bacharel em Direito pelo Centro Universitário de Brasília - UNICEUB e graduada em Letras - Língua e Literatura Japonesa pela Universidade de Brasília - UnB.

Revista Publicum

Rio de Janeiro, v. 3, n. 2, 2017, p. 286-338

http://www.e-publicacoes.uerj.br/index.php/publicum

DOI: 10.12957/publicum.2017.31883 


\begin{tabular}{|c|c|}
\hline 1. CASO & $\begin{array}{l}\text { CONFLITO ENTRE MINERAÇÃO E POVOS TRADICIONAIS } \\
\text { (DIREITO AO "BEM VIVER", À MORADIA E À SAÚDE) }\end{array}$ \\
\hline CLASSE E NÚMERO & $\begin{array}{l}\text { Sentença 001-10- SIN-CC } \underline{72} \\
\text { Casos no 0008-09- IN e 0011-09- IN } \\
\text { Ações de Inconstitucionalidade }\end{array}$ \\
\hline ÓRGÃO JULGADOR & Equador, Corte Constitucional, Pleno \\
\hline RELATOR & Juíza Constitucional Nina Pacari Veja \\
\hline REQUERENTE & $\begin{array}{l}\text { Marlon René Santi Gualinga - Presidente da Confederação de Nacionalidades } \\
\text { Indígenas do Equador; Carlos Pérez Guartambel - Presidente dos Sistemas } \\
\text { Comunitários de Água das Parroquias Tarqui, Victoria del Portete e outras } \\
\text { comunidades da província de Azuay. }\end{array}$ \\
\hline REQUERIDO & $\begin{array}{l}\text { Presidente da Comissão Legislativa e de Fiscalização da Assembleia Nacional; } \\
\text { Presidente da República do Equador; e o Procurador Geral do Estado. }\end{array}$ \\
\hline DATA DE JULGAMENTO & 18 de março de 2010 \\
\hline DATA DE PUBLICAÇÃo & $\begin{array}{l}\text { Registro Oficial Suplemento no } 176 \\
\text { 21.abr.2010 }\end{array}$ \\
\hline FATOS & $\begin{array}{l}\text { Os requeridos editaram e sancionaram a Lei de Mineração que possibilitava a } \\
\text { concessão e exploração de minérios dentro dos territórios indígenas e de povos } \\
\text { tradicionais sem a realização de consulta prévia a estas populações. A nova } \\
\text { legislação conferia liberdade de prospecção aos detentores de concessões de } \\
\text { mineração, impactando diretamente nos direitos à moradia, saúde, integridade } \\
\text { do território e buen vivir das populações tradicionais. }\end{array}$ \\
\hline $\begin{array}{l}\text { FUNDAMENTOS JURÍDICOS } \\
\text { DO PEDIDO }\end{array}$ & $\begin{array}{l}\text { Os requerentes fundamentam a pretensão inicial tanto na inconstitucionalidade } \\
\text { formal quanto na inconstitucionalidade material da Lei de Mineração. No que } \\
\text { tange à inconstitucionalidade formal, sustentam que a legislação } \\
\text { infraconstitucional não obedeceu à prescrição inscrita no art. 57, numeral 17, } \\
\text { da Constituição }{ }^{73} \text {, que impõe a realização de consulta prévia às populações } \\
\text { indígenas. Salientam que, nada obstante o dispositivo não tenha sido } \\
\text { regulamentado, lhe deve ser dada aplicação imediata, sob pena de serem } \\
\text { violados direitos fundamentais sociais das populações tradicionais relacionados } \\
\text { com o buen vivir. No que se refere à matéria de fundo, a inconstitucionalidade } \\
\text { da Lei de Mineração acha-se conectada com a possibilidade de livre exploração } \\
\text { dos territórios indígenas, com o estabelecimento de servidões e a declaração } \\
\text { de utilidade pública da terra. De acordo com os requerentes, tais institutos } \\
\text { induzem ao esgotamento dos territórios indígenas, permitindo a introdução de } \\
\text { atividades econômicas que se chocam com a cosmovisão de tais povos. } \\
\text { Ademais, tais atividades provocam o esgotamento dos recursos naturais, } \\
\text { induzindo o deslocamento forçado das populações indígenas e a violação de }\end{array}$ \\
\hline
\end{tabular}

72 EQUADOR. Corte Constitucional del Ecuador. Sentença 001-10-SiN-CC. Relator: Nina Pacari Vega. Registro Oficial no 176, 21.14.2010. Disponível em: <http://portal.corteconstitucional.gob.ec/Raiz/2010/001-10-SINCC/REL SENTENCIA 001-10-SIN-CC.pdf>. Acesso em: 30.nov.2017.

${ }^{73}$ EQUADOR. Constitución del Equador. Registro Oficial, 20 out. 2008. Art. 57, numeral 17: "São reconhecidas e garantidas as comunas, comunidades, povos e nacionalidades indígenas, de conformidade com a Constituição e com os pactos, convênios, declarações e demais instrumentos internacionais de direitos humanos os seguintes direitos coletivos: [...] 17. Ser consultados antes da adoção de uma medida legislativa que possa afetar qualquer de seus direitos coletivos" (livre tradução). Disponível em: $<$ http://www.asambleanacional.gov.ec/documentos/constitucion de bolsillo.pdf>. Acesso em 30.nov.2017. 


\begin{tabular}{|c|c|}
\hline & $\begin{array}{l}\text { seus direitos à moradia e à saúde (art. 6o da Convenção no } 169 \text { da } \text { OIT }^{74} \text { e art. } \\
19 \text { da Declaração dos Direitos dos Povos Indígenas }{ }^{75} \text { ). }\end{array}$ \\
\hline Pedido & $\begin{array}{l}\text { Os requerentes pretendem a declaração de inconstitucionalidade formal e } \\
\text { material da Lei de Mineração, em especial dos arts. } 1,2,15,22,26,28,30,31 \text {, } \\
43,67,79,96 \text {. }\end{array}$ \\
\hline $\begin{array}{l}\text { EMENTA OU TRECHO } \\
\text { DESTACADO }\end{array}$ & $\begin{array}{l}\text { "Esta Corte, com fundamento na Constituição da República do Equador, bem } \\
\text { como em instrumentos internacionais ratificados pelo país na matéria e na } \\
\text { jurisprudência nacional e internacional, identificará alguns standards relevantes } \\
\text { para dotar de eficácia prática a consulta prevista no numeral } 7 \text { do art. } 57 \text { da } \\
\text { Carta Fundamental, ante a ausência de norma infraconstitucional que o faça. } \\
\text { [...]. Uma consideração importante é o caráter substancial e não somente } \\
\text { processual da consulta prévia como direito coletivo, assim como o } \\
\text { reconhecimento do caráter medular do art. 6o do Convênio no } 169 \text { da OIT, } \\
\text { dentro do núcleo essencial do citado Convênio. Os parâmetros específicos } \\
\text { desenvolvidos pela OIT que deverão ser levados em conta são: a) o caráter } \\
\text { flexível do procedimento de consulta, que deve levar em conta o direito de cada } \\
\text { Estado e das tradições, usos e costumes dos povos consultados; b) o caráter } \\
\text { prévio da consulta [...]; c) o caráter público e informado da consulta; d) o } \\
\text { reconhecimento de que a consulta não se esgota na mera informação ou na } \\
\text { publicização da medida [...]; e) a obrigação de todos os indivíduos de atuarem } \\
\text { de boa fé. A consulta deve constituir um verdadeiro mecanismo de participação, } \\
\text { cujo objeto seja a busca do consenso entre os participantes; f) a difusão pública } \\
\text { e a destinação de um tempo razoável para cada uma das fases do processo [...]; } \\
\text { g) a definição prévia e concertada do procedimento [...]; h) a definição prévia e } \\
\text { concertada dos atores da consulta [...]; i) o respeito à estrutura social e aos } \\
\text { sistemas de autoridade e representação dos povos consultados [...]; j) o caráter } \\
\text { sistemático e formalizado da consulta [...]; I) quanto ao alcance da consulta, } \\
\text { embora ela não vincule o Estado e suas instituições, a opinião dos povos } \\
\text { consultados tem uma conotação jurídica especial, assemelhada ao soft law do } \\
\text { direito internacional [...]"76 (tradução livre). }\end{array}$ \\
\hline DECISÃO FINAL & $\begin{array}{l}\text { "1. Declarar que a consulta previa imposta pela Constituição tem caráter } \\
\text { substancial e não formal. } 2 \text {. Declarar a constitucionalidade condicionada dos } \\
\text { dispositivos } 15,28,31 \text { inciso segundo, } 59,87,88,90,10-105 \text { da Lei de } \\
\text { Mineração, frente aos arts. } 436 \text {, numerais } 1 \text { e } 3 \text { da Constituição da República e; } \\
\text { arts. } 5,76 \text {, numerais } 3-5 \text { e } 95 \text {, inciso primeiro, da Lei Orgânica de Garantias } \\
\text { Jurisdicionais e Controle Constitucional. Diante disso, os dispositivos apontados } \\
\text { serão constitucionais desde que sejam interpretados da seguinte maneira: a) } \\
\text { são constitucionais os artigos referidos desde não se apliquem aos territórios } \\
\text { indígenas; b) toda a atividade de mineração que se pretenda realizar nos }\end{array}$ \\
\hline
\end{tabular}

74 OIT. Convenção no 169 da OIT. Art. 6o: "Ao aplicar as disposições da presente Convenção, os governos deverão: a) consultar os povos interessados, mediante procedimentos apropriados e, particularmente, através de suas instituições representativas, cada vez que sejam previstas medidas legislativas ou administrativas suscetíveis de afetá-los diretamente" (livre tradução). Disponível em: <http://www.ilo.org/brasilia/convencoes/WCMS 236247/lang--pt/index.htm>. Acesso em: 30.nov.2017.

75 NAÇÕES UNIDAS. Declaração dos Direitos dos Povos Indígenas. "Art. 19. Os Estados consultarão e cooperarão com os povos indígenas interessados, por meio de suas instituições representativas, a fim de obter seu consentimento prévio e informado antes de adotar e aplicar medidas legislativas e administrativas que os afetem" (livre tradução). Disponível em:

<http://www.un.org/esa/socdev/unpfii/documents/DRIPS pt.pdf>. Acesso em: 30.nov.2017.

${ }^{76}$ EQUADOR. Corte Constitucional del Ecuador. Sentença 001-10-SiN-CC. Relator: Nina Pacari Vega. Registro Oficial no 176, 21.14.2010. Disponível em: <http://portal.corteconstitucional.gob.ec/Raiz/2010/001-10-SINCC/REL SENTENCIA 001-10-SIN-CC.pdf>. Acesso em: 30.nov.2017.

Revista Publicum

Rio de Janeiro, v. 3, n. 2, 2017, p. 286-338

http://www.e-publicacoes.uerj.br/index.php/publicum

DOI: $10.12957 /$ publicum.2017.31883 


\begin{tabular}{|l|l|}
\hline & $\begin{array}{l}\text { territórios das comunidades indígenas deverão submeter-se ao processo de } \\
\text { consulta prévia estabelecido no art. 57, numeral 7, da Constituição da República } \\
\text { até que a Assembleia Nacional edite legislação complementar"77 (tradução } \\
\text { livre). }\end{array}$ \\
\hline $\begin{array}{l}\text { VoTO VENCIDO } \\
\text { PARQUE O CASO É }\end{array}$ & $\begin{array}{l}\text { O caso é paradigmático porque estabeleceu a constitucionalidade condicionada } \\
\text { de diversos dispositivos da Lei de Mineração, dando a eles interpretação } \\
\text { conforme a Constituição. Além disso, o precedente normatizou a aplicação do } \\
\text { procedimento de consulta prévia, estabelecendo a obrigação da sua realização } \\
\text { a despeito da inexistência de regulamentação legislativa a respeito. A sentença } \\
\text { em tela foi alvo de diversos artigos acadêmicos }\end{array}$ \\
\hline $\begin{array}{l}\text { LINK: <http://portal.corteconstitucional.gob.ec/Raiz/2010/001-10-SIN-CC/REL SENTENCIA 001-10-SIN- } \\
\text { CC.pdf> }\end{array}$ \\
\hline PALAVRAS-CHAVE & $\begin{array}{l}\text { LEI DE MINERAÇÃO - CONSULTA PRÉVIA - DIREITO AO BEM VIVER - MORADIA } \\
\text {-SAÚDE - POVOS INDÍGENAS. }\end{array}$ \\
\hline
\end{tabular}

\begin{tabular}{|l|l|}
\hline 2. CASO & $\begin{array}{l}\text { INSEGURANÇA CIDADÃ } \\
\text { (SEGURANÇA PÚBLICA, DESIGUALDADE E NÃO ACESSO A DIREITOS SOCIAIS) }\end{array}$ \\
\hline CLASSE E NÚMERO & $\begin{array}{l}\text { Sentença 005-09- SEE-CC79 } \\
\text { Controle de Constitucionalidade de Estado de Exceção no 0006-09- EE }\end{array}$ \\
\hline ÓRGÃO JULGADOR & Equador, Corte Constitucional, Pleno \\
\hline RELATOR & Juiz Constitucional Hernando Morales Vinueza \\
\hline REQUERENTE & Presidente da República do Equador Rafael Côrrea Delgado \\
\hline REQUERIDO & Não há. \\
\hline DATA DE JULGAMENTO & 08 de outubro de 2009 \\
\hline DATA DE PUBLICAÇÃo & $\begin{array}{l}\text { Registro Oficial Suplemento no 50 } \\
\text { 20.out.2009 }\end{array}$ \\
\hline FATOS & $\begin{array}{l}\text { No dia 30 de setembro de 2009, por meio do Decreto Executivo no 82, o } \\
\text { Presidente da República do Equador declarou estado de exceção nas cidades de } \\
\text { Quito, Guayaquil e Manta, pelos altos índices de delinquência e aumento da } \\
\text { insegurança cidadã. De acordo com o Decreto, os atos delitivos registrados } \\
\text { nessas cidades estariam causando grave comoção no país. O principal objetivo } \\
\text { do edito era permitir que as Forças Armadas colaborassem com a Polícia } \\
\text { Nacional nas operações de controle delinquencial. }\end{array}$ \\
\hline $\begin{array}{l}\text { FUNDAMENTOS JURíDICOS } \\
\text { Do PEDIDO }\end{array}$ & $\begin{array}{l}\text { Os ordenamentos constitucionais dos Estados em geral são concebidos para } \\
\text { regular situações ordinárias da vida diária, o que significa afirmar que nascem } \\
\text { para reger fatos que se desenvolvem sob condições de normalidade. Neste viés, }\end{array}$ \\
\hline
\end{tabular}

77 EQUADOR. Corte Constitucional del Ecuador. Sentença 001-10-SiN-CC. Relator: Nina Pacari Vega. Registro Oficial no 176, 21.14.2010. Disponível em: <http://portal.corteconstitucional.gob.ec/Raiz/2010/001-10-SINCC/REL SENTENCIA 001-10-SIN-CC.pdf>. Acesso em: 30.nov.2017.

${ }^{78}$ CEVALLOS, José García. La consulta prévia como derechos de los pueblos indigenas. Sentencia 001-10-SINCC, casos 0008-09-IN y 0011-09-IN. Declaracion de inconstitucionalidad por la forma y el fondo de la ley de Mineria, in Revista de Derecho Ambiental, ano 4, no 1 . Disponível em: <http://www.palermo.edu/derecho/pdf/publicaciones/Revista DerechoAmbiental Ano4>. Acesso em: 30.nov.2017 e LOZANO, Santiago Machuca. Analisis de la sentencia 001-10-SIN-CC. Casos 0008-09-IN e 001109-IN sobre ação de inconstitucionalidad de la ley de Mineria y sus efectos posteriores, in Revista de Derecho, UASB, no 21, no sítio http://repositorio.uasb.edu.ec/bitstream/10644/4581/1/09-Jurisprudencia.pdf.

79 EQUADOR. Corte Constitucional del Ecuador. Sentença 005-09-SEE-CC. Relator: Hernando Morales Vinueza. Registro Oficial no 50, 20.10.2009. Disponível em: <http://portal.corteconstitucional.gob.ec/Raiz/2009/005-09-SEE-CC/REL SENTENCIA 005-09-SEE-CC.pdf>. Acesso em: 30.nov.2017.

Revista Publicum

Rio de Janeiro, v. 3, n. 2, 2017, p. 286-338

http://www.e-publicacoes.uerj.br/index.php/publicum

DOI: 10.12957/publicum.2017.31883 


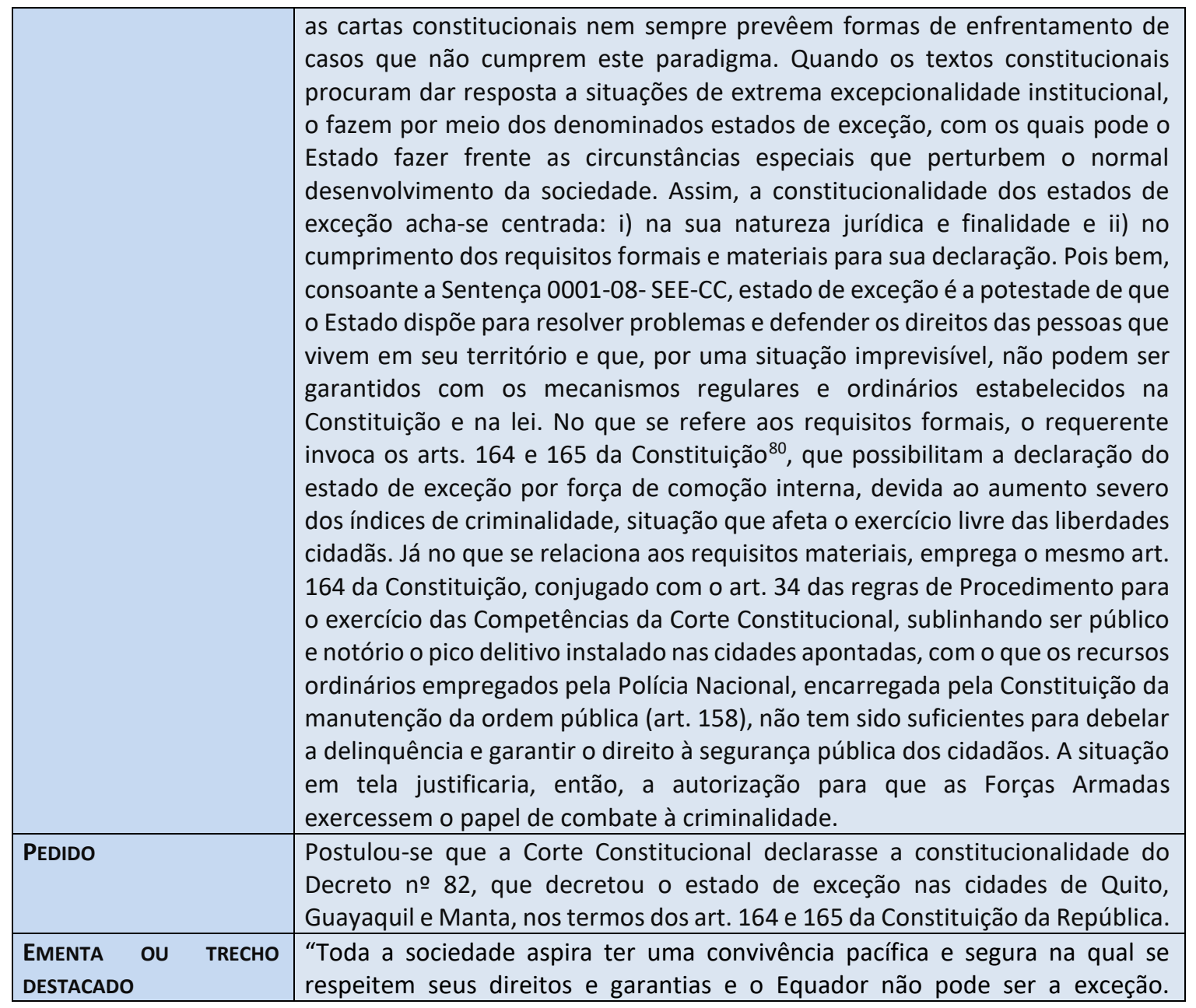

${ }^{80}$ EQUADOR. Constitución del Equador. Registro Oficial, 20 out. 2008. “Art. 164. A Presidenta ou o Presidente da República poderá decretar o estado de exceção em todo o território nacional ou em parte dele em caso de agressão, conflito armado internacional ou interno, grave comoção interna, calamidade pública ou desastre natural. A declaração do estado de exceção não interromperá as atividades das funções de Estado. O Estado de exceção obedecerá aos princípios da necessidade, proporcionalidade, legalidade, temporalidade, territorialidade e razoabilidade. 0 decreto que estabelece o estado de exceção conterá a determinação da causa e a sua motivação, âmbito territorial de aplicação, o período de duração, as medidas que deverão ser aplicadas, os direitos que poderão ser suspendidos ou limitados e as notificações determinadas pela Constituição e pelos tratados internacionais" (livre tradução). Art. 165 da Constituição do Equador: "Durante o estado de exceção, a Presidenta ou o Presidente da República poderá unicamente suspender ou limitar o exercício do direito à inviolabilidade do domicílio, inviolabilidade de correspondência, liberdade de trânsito, liberdade de associação e reunião e liberdade de informação, nos termos assinalados pela Constituição. Declarado o estado de exceção, a Presidente ou o Presidente da República poderá: 1. Decretar a arrecadação antecipada de tributos. 2. Utilizar os fundos públicos destinados a outros fins, exceto os correspondentes à saúde e educação. 3. Trasladar a sede do governo para qualquer lugar do território nacional. 4. Realizar censura prévia da informação dos meios de comunicação social com estrita relação aos motivos do estado de exceção e à segurança do Estado. 5. Estabelecer como zona de segurança todo ou parte do território nacional. 6. Empregar as Forças Armadas e a Polícia Nacional e convocar o serviço ativo e a reserva ou uma parte dela, assim como o pessoal de outras instituições. 7. Determinar o fechamento de portos, aeroportos e espaços de fronteira. 8. Determinar a mobilização e as requisições que sejam necessárias e decretar a desmobilização nacional quando se restabeleça a normalidade" (livre tradução). Disponível em: <http://www.asambleanacional.gov.ec/documentos/constitucion de bolsillo.pdf>. Acesso em: 30.nov.2017.

Revista Publicum

Rio de Janeiro, v. 3, n. 2, 2017, p. 286-338

http://www.e-publicacoes.uerj.br/index.php/publicum

DOI: 10.12957/publicum.2017.31883 


\begin{tabular}{|c|c|}
\hline & $\begin{array}{l}\text { Todavia, existem causas que motivam que esta paz e segurança se veja } \\
\text { ameaçada pela conduta delinquente de alguns membros da sociedade. Mas ao } \\
\text { analisar as causas que motivam a delinquência, é evidente que tais condutas } \\
\text { delitivas derivam das condições econômicas e sociais que se expressam na } \\
\text { inequitativa distribuição de riqueza, na falta de oportunidades de acesso à } \\
\text { educação, na falta de fontes de trabalho, na pobreza, males que não foram } \\
\text { enfrentados de maneira eficiente, sendo responsabilidade governamental dar- } \\
\text { lhes imediata solução, com a adoção de uma política econômica que modifique } \\
\text { as condições de desigualdade, a fim de que se alcance o ideal de uma sociedade } \\
\text { justa, solidária, livre de toda forma de discriminação, na qual já não seja } \\
\text { necessária a aplicação de medidas drásticas como os estados de exceção. } \\
\text { Entretanto, dadas as condições atuais, de alto nível delitivo, se faz necessária a } \\
\text { medida adotada pelo Executivo, a fim de dar resposta imediata a este mal que } \\
\text { afeta aos cidadãos. As Forças Armadas têm como missão fundamental a defesa } \\
\text { da soberania e integridade territorial. Contudo, devido ao estado de comoção } \\
\text { em que vivem os cidadãos de Quito, Guayaquil e Manta, se justifica a } \\
\text { participação militar durante o estado de exceção, visto que as Forças Armadas, } \\
\text { como a Polícia Nacional, são instrumentos de proteção dos direitos e liberdades } \\
\text { e garantias dos cidadãos" (tradução livre) }{ }^{81} \text {. }\end{array}$ \\
\hline DECISÃO FINAL & $\begin{array}{l}\text { "1. Declarar a constitucionalidade formal e material da declaração de estado de } \\
\text { exceção, contida no Decreto Executivo } n \text { o } 82 \text {, de } 30 \text { de setembro de } 2009 \text {, } \\
\text { subscrito por Rafael Correa Delgado, Presidente Constitucional da República. } 2 \text {. } \\
\text { Sem prejuízo do exercício das competências de controle constitucional } \\
\text { inerentes a esta Corte, se exorta os agentes da Força Pública a adotar os } \\
\text { esforços e precauções para garantir e proteger os direitos constitucionais e } \\
\text { cumprir com o objetivo perseguido pelo Decreto. É de se registar que a Corte } \\
\text { Constitucional asseverou que, embora as causas do aumento da criminalidade } \\
\text { e da insegurança derivem das condições econômicas e sociais, que apontam } \\
\text { para a inequitativa distribuição de renda, para a falta de acesso à educação, } \\
\text { para a falta de fontes de trabalho, para a pobreza, e tenha reconhecido que tais } \\
\text { males não têm sido enfrentados de forma eficiente pelo Estado, aquiesceu com } \\
\text { a necessidade de emprego das Forças Armadas para a garantia das liberdades } \\
\text { cidadãs, como medida excepcional e que não deve ser banalizada" } 82 \text { (tradução } \\
\text { livre). }\end{array}$ \\
\hline VOTO VENCIDO & Decisão unânime. \\
\hline $\begin{array}{l}\text { PORQUE O CASO É } \\
\text { PARADIGMÁTICO }\end{array}$ & $\begin{array}{l}\text { O caso é paradigmático porque reconhece a constitucionalidade do decreto } \\
\text { executivo que estabelece estado de exceção, com vistas à utilização das Forças } \\
\text { Armadas, em razão do aumento da criminalidade, sem qualquer critério } \\
\text { científico para a confirmação deste suposto incremento. Com isso, a Corte } \\
\text { estabeleceu um padrão de chancela de modificação das competências } \\
\text { constitucionais para o exercício da atividade de segurança pública, com base } \\
\text { em critério genérico. A sentença é referida em periódicos que analisam a } \\
\text { produção da Corte Constitucional Equatoriana, como o Guia de Jurisprudência }\end{array}$ \\
\hline
\end{tabular}

81 EQUADOR. Corte Constitucional del Ecuador. Sentença 005-09-SEE-CC. Relator: Hernando Morales Vinueza. Registro Oficial no 50, 20.10.2009.

82 EQUADOR. Corte Constitucional del Ecuador. Sentença 005-09-SEE-CC. Relator: Hernando Morales Vinueza. Registro Oficial no 50, 20.10.2009.

Revista Publicum

Rio de Janeiro, v. 3, n. 2, 2017, p. 286-338

http://www.e-publicacoes.uerj.br/index.php/publicum

DOI: 10.12957/publicum.2017.31883 


\begin{tabular}{|c|c|}
\hline & $\begin{array}{l}\text { Constitucional Equatoriana }{ }^{83} \text { e a publicação periódica do Colégio de } \\
\text { Jurisprudência da Universidad San Francisco de Quito, luris Dictio }{ }^{84} \text {. }\end{array}$ \\
\hline \multicolumn{2}{|c|}{$\begin{array}{l}\text { LINK: http://portal.corteconstitucional.gob.ec/Raiz/2009/005-09-SEE-CC/REL SENTENCIA 005-09-SEE- } \\
\text { CC.pdf }\end{array}$} \\
\hline$\overline{\text { PALAVRAS-CHAVE }}$ & $\begin{array}{l}\text { ESTADO DE EXCEÇÃO - INSEGURANÇA CIDADÃ - ÍNDICES DE VIOLÊNCIA - } \\
\text { FORÇAS ARMADAS }\end{array}$ \\
\hline
\end{tabular}

\begin{tabular}{|l|l|}
\hline 3. CASO & $\begin{array}{l}\text { UNIVERSIDADE INTERCULTURAL PARA INDÍGENAS } \\
\text { (ACESSO À EDUCAÇÃO SUPERIOR PELOS POVOS INDÍGENAS) }\end{array}$ \\
\hline CLASSE E NÚMERO & $\begin{array}{l}\text { Sentença no 0008-09- SAN-CC } \\
\text { Caso }\end{array}$ \\
Aço 0027-09- AN
\end{tabular}

83 VELASCO, Angélica Porras. Guia de Jurisprudência Constitucional Equatoriana, Quito: Centro de Estudios y Difusion del Derecho Constitucional, tomo II, 2010, p. 288.

${ }^{84}$ ANDRADE, Juan Pablo Aguilar. Entre la retórica de lo nuevo y la persistencia del pasado: La Corte Constitucional y los estados de excepción, in Iuris Dictio: Universidad San Francisco de Quito, 2010, № 13, p. 59.

${ }^{85}$ EQUADOR. Corte Constitucional del Ecuador. Sentença 0008-09-SAN-CC. Relator: Nina Pacari Vega. Registro Oficial no 97, 29.12.2009. Disponível em: <https://www.corteconstitucional.gob.ec/images/contenidos/gaceta-constitucional/Gaceta011.pdf>. Acesso em: 30.nov.2017. 


\begin{tabular}{|l|l|}
\hline FUNDAMENTOS JURÍDICOS & $\begin{array}{l}\text { Alega-se que os programas acadêmicos dos centros de saber devem chegar até } \\
\text { as comunidades onde se encontram assentadas originária, histórica e } \\
\text { ancestralmente as nacionalidades e povos indígenas. Na realidade dos povos } \\
\text { indígenas, o conhecimento está na natureza, no próprio povo indígena e no seu } \\
\text { entorno, de tal forma que são os centros de estudo que devem mudar-se para } \\
\text { nutrir-se de seu saber. Impor o contrário atesta a incompreensão das } \\
\text { realidades e da própria cultura indígena. Aplicação dos princípios da } \\
\text { continuidade histórica, da diversidade cultural, da interculturalidade e da } \\
\text { interpretação intercultural. No que diz respeito a este último, destaca a enorme } \\
\text { contribuição da Corte Constitucional colombiana para a definição de regras de } \\
\text { interpretação que representem maior conservação dos usos e costumes e } \\
\text { autonomia dos povos e a primazia dos usos e costumes de uma comunidade } \\
\text { sobre as normas legais. A Constituição equatoriana estabelece que nenhuma } \\
\text { norma secundária pode restringir, limitar ou tornar ineficaz os direitos dos } \\
\text { povos e nacionalidades indígenas (arts. 56 e 57, 1, 9, 10-12, 14 da Constituição } \\
\text { equatoriana }{ }^{86} \text { e bloco de constitucionalidade formado pelos arts. 2o, 30 e } 27 \text { da } \\
\text { Convenção no } 169 \text { sobre os Direitos Civis e Políticos da OlT }{ }^{87} \text { ). }\end{array}$ \\
\hline
\end{tabular}

86 EQUADOR. Constitución del Equador. Registro Oficial, 20 out. 2008. Art. 5o: “As comunidades, povos, e nacionalidades indígenas, o povo afroecuatroriano, o povo montúbio e as comunidades são parte do Estado equatoriano, único e indivisível". Art. 57: "Se reconhece e garante às comunas, comunidades, povos e nacionalidades indígenas, em conformidade com a Constituição e com os pactos, convênios, declarações e demais instrumentos internacionais de direitos humanos, os seguintes direitos coletivos: [...]. 12. Manter, proteger e desenvolver os conhecimentos coletivos; suas ciências, tecnologias e saberes ancestrais; [...]; 14. Desenvolver, fortalecer e potencializar o sistema de educação intercultural bilingue, com critérios de qualidade, desde o ensino infantil até o nível superior, conforme a diversidade cultural, para o cuidado e a preservação das identidades, em consonância com suas metodologias de ensino e aprendizagem. [...]". Art. 10: "O Equador é um Estado constitucional de direitos e justiça social, democrático, soberano, independente, unitário, intercultural, plurinacional e laico [...]". Art. 10: "As pessoas, comunidades, povos, nacionalidades e coletividades são titulares dos direitos garantidos na Constituição e nos instrumentos internacionais. A natureza será sujeito daqueles direitos reconhecidos na Constituição." Art. 11: " O exercício dos direitos se regerá pelos seguintes princípios: [...] 2. Todas as pessoas são iguais e gozarão dos mesmos direitos, deveres e oportunidades. Ninguém poderá ser discriminado por razões de etnia, lugar de nascimento, idade, sexo, identidade de gênero, identidade cultural, estado civil, idioma, religião, ideologia, filiação política, passado judicial, condição sócio-econômica, condição migratória, orientação sexual, estado de saúde, portar HIV, incapacidade, diferença física, nem qualquer outra distinção, pessoal ou coletiva, temporal ou permanente, que tenha por objetivo menosprezar ou anular o reconhecimento, gozo ou exercício dos direitos [...]". Art. 12: "O direito humano à água é irrenunciável. A água constitui patrimônio nacional estratégico de uso público, inalienável, imprescritível, insuscetível de embargo e essencial à vida". Art. 14: Fica reconhecido o direito da população a viver em um meio ambiente são e ecologicamente equilibrado, que garanta a sustentabilidade e o bem viver, "sumak kawsay"”." Disponível em: <http://www.asambleanacional.gov.ec/documentos/constitucion de bolsillo.pdf>. Acesso em: 30.nov.2017. Livre tradução.

87 OIT. Convenção no 169 da OIT. Art. 20: "1.Os governos deverão assumir a responsabilidade de desenvolver, com a participação dos povos interessados, uma ação coordenada e sistemática com vistas a proteger os direitos desses povos e a garantir o respeito pela sua integridade. 2. Essa ação deverá incluir medidas: a) que assegurem aos membros desses povos o gozo, em condições de igualdade, dos direitos e oportunidades que a legislação nacional outorga aos demais membros da população; b) que promovam a plena efetividade dos direitos sociais econômicos e culturais desses povos, respeitando a sua identidade social e cultural, os seus costumes e tradições e as suas instituições; c) que ajudem os membros dos povos interessados a eliminar as diferenças sócio-econômicas que possam existir entre membros indígenas e os demais membros da comunidade nacional, de maneira compatível com suas aspirações e formas de vida". Art. 3:. "1. Os povos indígenas e tribais deverão gozar plenamente dos direitos humanos e liberdades fundamentais, sem obstáculos nem discriminação [...]. 2. Não deverá ser empregada nenhuma forma de força ou de coerção que viole os direitos humanos e as liberdades fundamentais dos povos interessados, inclusive os direitos contidos na presente Convenção”. Art. 27: "1. Os programas e serviços de educação destinados aos povos interessados 


\begin{tabular}{|c|c|}
\hline PedIDo & $\begin{array}{l}\text { Postulou-se que a Corte Constitucional declarasse o descumprimento pelo } \\
\text { CONESUP dos preceitos insculpidos nos art. } 56 \text { e 57, 1,9,10-12, } 14 \text { da } \\
\text { Constituição equatoriana e no bloco de constitucionalidade formado pelos arts. } \\
2 \text { o }, 30 \text { e } 27 \text { da Convenção no } 169 \text { sobre os Direitos Civis e Políticos da OIT, } \\
\text { assentando que estratificam princípios com perspectiva intercultural e, por } \\
\text { consequência, que o Conselho deferisse o funcionamento dos programas } \\
\text { acadêmicos nas localidades próximas às comunidades tradicionais e indígenas. }\end{array}$ \\
\hline $\begin{array}{l}\text { EMENTA OU TRECHO } \\
\text { DESTACADO }\end{array}$ & $\begin{array}{l}\text { "Os programas acadêmicos ou os centros de saber devem chegar até as } \\
\text { comunidades onde se encontram assentadas originária, histórica e } \\
\text { ancestralmente as nacionalidades e povos indígenas, abandonando aquele } \\
\text { tratamento convencional pelo qual as pessoas devem dirigir-se a um centro de } \\
\text { estudos, mesmo que longínquo, em busca de conhecimento. Na realidade dos } \\
\text { povos indígenas o conhecimento está na natureza, no seu entorno e nos seus } \\
\text { próprios costumes, de tal forma que são os centros de estudo que devem se } \\
\text { deslocar para que possam nutrir-se dos saberes e conhecimentos destes povos. } \\
\text { Impor o contrário, ou seja, impor que os centros de estudo tenham uma única } \\
\text { sede distante dos povos que pretendem atender significa desconhecer as } \\
\text { realidades e a própria cultura indígena. Pretender dar um tratamento } \\
\text { semelhante ao da educação convencional a um centro de educação } \\
\text { intercultural bilingüe, cuja natureza responde à cosmovisão e a realidades } \\
\text { distintas, evidencia uma desnaturação do objetivo inicial de sua criação. O } \\
\text { direito de educação intercultural, o respeito pelos conhecimentos ancestrais, } \\
\text { seu manejo, estrutura e desenvolvimento não podem ficar submetidos a um } \\
\text { critério estranho à sua realidade e cosmovisão. A Constituição equatoriana } \\
\text { estabelece que nenhuma norma inferior pode restringir, limitar ou tornar } \\
\text { ineficaz direitos fundamentais, como o que aqui se discute. É importante que } \\
\text { naqueles casos nos quais se está de frente a direitos coletivos, particularmente } \\
\text { aqueles pertencentes a povos e nacionalidades indígenas, sejam observados } \\
\text { princípios com perspectiva intercultural, tais como: continuidade histórica, } \\
\text { diversidade cultural, interculturalidade e interpretação intercultural" } 88 \\
\text { (tradução livre). }\end{array}$ \\
\hline
\end{tabular}

deverão ser desenvolvidos e aplicados em cooperação com eles a fim de responder às suas necessidades particulares, e deverão abranger a sua história, seus conhecimentos e técnicas, seus sistemas de valores e todas suas demais aspirações sociais, econômicas e culturais. 2. A autoridade competente deverá assegurar a formação de membros destes povos e a sua participação na formulação e execução de programas de educação, com vistas a transferir progressivamente para esses povos a responsabilidade de realização desses programas, quando for adequado. 3. Além disso, os governos deverão reconhecer o direito desses povos de criarem suas próprias instituições e meios de educação, desde que tais instituições satisfaçam as normas mínimas estabelecidas pela autoridade competente em consulta com esses povos. Deverão ser facilitados para eles recursos apropriados para essa finalidade". Disponível em: <http://www.ilo.org/brasilia/convencoes/WCMS 236247/lang--pt/index.htm>. Acesso em: 30.nov.2017. ${ }^{88}$ EQUADOR. Corte Constitucional del Ecuador. Sentença 0008-09-SAN-CC. Relator: Nina Pacari Vega. Registro Oficial no 97, 29.12.2009. Disponível em: <https://www.corteconstitucional.gob.ec/images/contenidos/gaceta-constitucional/Gaceta011.pdf>. Acesso em: 30.nov.2017. 


\begin{tabular}{|c|c|}
\hline DECISÃO FINAL & $\begin{array}{l}\text { "1. Aceitar a ação por descumprimento aforada pela Universidade Intercultural } \\
\text { das Nacionalidades e Povos Indígenas AMAWTAY WASI. } \\
\text { 2. Declarar o descumprimento por parte do CONESUP do art. 4o da Lei de } \\
\text { Criação da Universidade Intercultural das Nacionalidades e Povos Indígenas } \\
\text { AMAWTAY WASI e do art. } 31 \text { do Estatuto Orgânico da Universidade } \\
\text { Intercultural das Nacionalidades e Povos Indígenas AMAWTAY WASI. } \\
\text { 3. Determinar que o CONESUP incorpore em todos os seus atos jurídico- } \\
\text { administrativos que tenham relação com nacionalidades e povos indígenas, } \\
\text { afrodescendentes e montúbios, princípios com perspectiva intercultural, de } \\
\text { forma a aplicar em sua integralidade os direitos destes povos, de acordo com } \\
\text { o exposto e considerado nesta sentença. } \\
\text { 4. Em concordância com a Convenção no } 169 \text { da OIT, o CONESUP se sujeitará, } \\
\text { no que se refere à autorização solicitada pela Universidade Intercultural das } \\
\text { Nacionalidades e Povos Indígenas AMAWTAY WASI, às disposições da dita } \\
\text { Convenção, no seguinte: a) a abertura de programas acadêmicos nos territórios } \\
\text { das nacionalidades e povos indígenas segundo sua cultura e cosmovisão; b) } \\
\text { pleno exercício da autonomia universitária, com desenvolvimento de } \\
\text { modalidades próprias, que ponham em prática seus métodos de } \\
\text { aprendizagem, e que isto sirva como um aporte inovador das nacionalidades e } \\
\text { povos indígenas ao Sistema Nacional de Educação Superior; c) implementação } \\
\text { de métodos próprios de aprendizagem, suas modalidades, planos ou } \\
\text { programas educacionais, em consonância com seus centros de saber e em } \\
\text { conformidade com as leis que Ihes deram gênese, em estrito respeito aos } \\
\text { direitos das nacionalidades e povos indígenas reconhecidos na Constituição da } \\
\text { República"89 (tradução livre). }\end{array}$ \\
\hline VOTO VENCIDO & Decisão unânime. \\
\hline $\begin{array}{l}\text { PORQUE O CASO É } \\
\text { PARADIGMÁTICO }\end{array}$ & $\begin{array}{l}\text { O caso é paradigmático não só porque garantiu a prevalência do princípio da } \\
\text { interculturalidade sobre normas internas de ensino, permitindo que uma } \\
\text { Universidade funcionasse em bases diferentes das tradicionais, mas sobretudo } \\
\text { porque impôs a incorporação do princípio pelo próprio sistema de ensino. O } \\
\text { precedente em tela é referenciado em diversas publicações, dentre elas o Guia } \\
\text { de Jurisprudência Constitucional Equatoriana }{ }^{90} \text {; o Guia para a Transversalidade } \\
\text { do Princípio da Interculturalidade na Justiça Ordinária }{ }^{91} \text {; e o Questionário } \\
\text { respondido pela Corte Constitucional Equatoriana por ocasião do 3o Congresso } \\
\text { da Convenção Mundial da Justiça Constitucional }{ }^{92} \text {. }\end{array}$ \\
\hline \multicolumn{2}{|c|}{$\begin{array}{l}\text { LINK: http://portal.corteconstitucional.gob.ec/Raiz/2009/008-09-SAN-CC/REL SENTENCIA 008-09-SAN- } \\
\text { CC.pdf }\end{array}$} \\
\hline PALAVRAS-CHAVE & $\begin{array}{l}\text { POVOS INDÍGENAS - EDUCAÇÃO - INTERCULTURALIDADE - IGUALDADE - } \\
\text { DIVERSIDADE CULTURAL - CONTINUIDADE HISTÓRICA. }\end{array}$ \\
\hline
\end{tabular}

${ }^{89}$ EQUADOR. Corte Constitucional del Ecuador. Sentença 0008-09-SAN-CC. Relator: Nina Pacari Vega. Registro Oficial no 97, 29.12.2009. Disponível em: <https://www.corteconstitucional.gob.ec/images/contenidos/gaceta-constitucional/Gaceta011.pdf> Acesso em: 30.nov.2017.

$9^{0}$ VELASCO, Angélica Porras. Guia de Jurisprudência Constitucional Equatoriana, Quito:Centro de Estudios y Difusion del Derecho Constitucional, tomo I, 2010, p. 168.

${ }^{91}$ GAONA, Maria Verónica Espinel. Guia para la transversalizacion del princípio de interculturalidad en la justicia ordinaria, Quito:Consejo de la Judicatura, 2016.

92 Respuesta ao cuestionário del 30 Congress of the World Conference on Constitucional Justice Constitucional Justice and Social Integration, 28 september -1october 2014, Seoul Korea. Disponível em: $<$ http://www.venice.coe.int/WCCJ/Seoul/docs/Ecuador CC reply questionnaire-3WCCJ-ESP.pdf>. Acesso em: 30.nov.2017. 
Revista Publicum

Rio de Janeiro, v. 3, n. 2, 2017, p. 286-338

http://www.e-publicacoes.uerj.br/index.php/publicum

DOI: 10.12957/publicum.2017.31883 


\begin{tabular}{|c|c|}
\hline 4. CASO & $\begin{array}{l}\text { HORMÔNIO DE CRESCIMENTO } \\
\text { (DIREITO À SAÚDE) }\end{array}$ \\
\hline CLASSE E NÚMERO & $\begin{array}{l}\text { Sentença 074-16- SIS-CC } 93 \\
\text { Caso no 0010-14- IS } \\
\text { Ação de Descumprimento }\end{array}$ \\
\hline ÓRGÃO JULGADOR & Equador, Corte Constitucional, Pleno \\
\hline RELATOR & Juíza Constitucional Ruth Seni Pinoargote \\
\hline REQUERENTE & Santiago Noé Vasco Morales \\
\hline REQUERIDO & Ministro da Saúde Pública \\
\hline DATA DE JULGAMENTO & 12.dez.2016 \\
\hline DATA DE PUBLICAÇÃO & $\begin{array}{l}\text { Registro Oficial Suplemento Edição Especial no } 800 \\
\text { 15.dez. } 2016\end{array}$ \\
\hline FATOS & $\begin{array}{l}\text { Representantes de crianças portadoras da Síndrome de Larón, responsável por } \\
\text { severo retardo no crescimento, que necessitam do medicamento de alto custo } \\
\text { MECASERMINA, nome de marca INCRELEX, do Laboratório Pisen, ajuizaram } \\
\text { ação de proteção perante o Tribunal de Garantias Penais de Pichincha. Em } \\
\text { resposta à demanda, a Corte em questão determinou: (i) a formação de uma } \\
\text { comissão bipartite composta por médicos e representantes do Ministério da } \\
\text { Saúde; (ii) a apresentação pelos autores de um protocolo de lineamento técnico } \\
\text { ao Ministério da Saúde; e (iii) a confecção pelo Ministério da Saúde de um plano } \\
\text { razoável para o apoio médico direcionado ao tratamento das crianças } \\
\text { equatorianas acometidas pela Síndrome de Larón. Como o Ministério da Saúde } \\
\text { estaria criando embaraços ao cumprimento da determinação judicial, o autor } \\
\text { aforou ação de descumprimento perante a Corte Constitucional do Equador. }\end{array}$ \\
\hline $\begin{array}{l}\text { FUNDAMENTOS JURÍDICOS } \\
\text { DO PEDIDO }\end{array}$ & $\begin{array}{l}\text { De acordo com o art. } 32 \text { da Constituição da República }{ }^{94} \text {, a saúde é um direito } \\
\text { garantido pelo Estado, que se encontra articulado com o cumprimento e a } \\
\text { eficácia de outros direitos constitucionais, tais como o direito à água, à } \\
\text { alimentação, à educação, ao trabalho, à seguridade social, ao ambiente } \\
\text { saudável, dentre outros e cujo adequado exercício se perfectibiliza através de } \\
\text { políticas públicas. Bem por isso que o direito à saúde se encontra alinhado com } \\
\text { o Sistema Nacional de Saúde, que tem como finalidade o desenvolvimento, a } \\
\text { proteção e a recuperação das capacidades e potencialidades para uma vida } \\
\text { saudável e integral, tanto individual quanto coletiva. Este sistema abarca todas } \\
\text { as dimensões do direito à saúde e compreende todas as instituições, } \\
\text { programas, políticas, recursos, ações e atores voltados para o cumprimento das } \\
\text { finalidades acima indicadas. A Corte Constitucional do Equador, no precedente } \\
\text { 016-16- SEP-CC, já havia se pronunciado no sentido de que a Constituição da } \\
\text { República orienta a tarefa do Estado de adotar a política pública necessária para } \\
\text { a universalização da atenção à saúde; a melhoria de sua qualidade e a ampliação } \\
\text { da cobertura existente. No mesmo precedente, a Corte garantiu que todos os } \\
\text { direitos contidos na Carta Constitucional gozam de igual hierarquia, sendo } \\
\text { plenamente justiciáveis, pelo que a saúde constitui obrigação do Estado, que }\end{array}$ \\
\hline
\end{tabular}

93 EQUADOR. Corte Constitucional del Ecuador. Sentença 074-16-SIS-CC. Relator: Ruth Seni Pinoargote Registro Oficial $\quad n$ o 800, 15.12.2016. Disponível em: <http://portal.corteconstitucional.gob.ec/Raiz/2016/074-16-SIS-CC/REL SENTENCIA 074-16-SIS-CC.pdf>. Acesso em: 30.nov.2017.

${ }^{94}$ EQUADOR. Constitución del Equador. Registro Oficial, 20 out. 2008.. Art. 32: “A saúde é um direito garantido pelo Estado, cuja realização se vincula ao exercício de outros direitos, dentre eles o direito à água, à alimentação, à educação, à cultura física, ao trabalho, à seguridade social, aos ambientes sãos e outros que sustentam o bem viver" (livre tradução). Disponível em $<$ http://www.asambleanacional.gov.ec/documentos/constitucion de bolsillo.pdf $>$. Acesso em: 30.nov.2017. 


\begin{tabular}{|c|c|}
\hline & $\begin{array}{l}\text { está encarregado de garantir seu efetivo gozo (art. } 226 \text { da Constituição). Não } \\
\text { fora isso, os arts. } 35 \text { e } 45 \text { da Constituição }{ }^{95} \text { determinam que crianças e } \\
\text { adolescentes devem receber atenção prioritária e especializada nos âmbitos } \\
\text { público e privado, sendo dever do Estado prestar especial proteção a elas. Daí } \\
\text { porque as crianças com Síndrome de Larón devem receber do Estado a } \\
\text { assistência médica e farmacêutica de que necessitam. Citados precedentes da } \\
\text { Corte Constitucional da Colômbia T-418/11 e T-057/15. }\end{array}$ \\
\hline PEDIDo & $\begin{array}{l}\text { Postulou-se que a Corte Constitucional promovesse a destituição da Ministra da } \\
\text { Saúde Pública pelo descumprimento imotivado da sentença prolatada pelo } \\
\text { Tribunal de Garantias Penais de Pichincha. }\end{array}$ \\
\hline $\begin{array}{l}\text { EMENTA OU TRECHO } \\
\text { DESTACADO }\end{array}$ & $\begin{array}{l}\text { "Resulta clara a obrigação do Estado, no que se refere ao direito de crianças e } \\
\text { adolescentes com Síndrome de Larón, de executar todo o conjunto de } \\
\text { prestações ou ações positivas e/ou negativas, de maneira progressiva, que } \\
\text { garantam o seu exercício efetivo. Neste contexto, a Corte Constitucional estima } \\
\text { pertinente assinalar que a implementação e execução do conjunto de } \\
\text { prestações ou ações referidas no parágrafo anterior deverá ser levada a termo } \\
\text { pelas diferentes instâncias estatais, de uma maneira diligente, eficiente, eficaz } \\
\text { e em estrita observância ao princípio de cooperação previsto no art. } 226 \text { da } \\
\text { Constituição do Equador. Em consequência, crianças e adolescentes que } \\
\text { padecem de Síndrome de Larón têm o direito pleno à saúde já que em sua } \\
\text { condição de dupla vulnerabilidade não somente são os titulares dele, como têm } \\
\text { direito de gozar de todos os componentes que o integram, dentre eles o direito } \\
\text { humano aos medicamentos, para os quais o legislador e a autoridade sanitária } \\
\text { nacional estabeleceram um amplo conjunto de prestações ou ações positivas, } \\
\text { tais como a emissão de protocolos para garantir a eficácia progressiva do } \\
\text { tratamento" }\end{array}$ \\
\hline DECISÃO FINAL & $\begin{array}{l}\text { "1. Declarar o descumprimento da sentença emitida em } 1 \text { de dezembro de } 2010 \\
\text { pelo Tribunal Segundo de Garantias Penais de Pichincha na ação de proteção } \\
\text { movida contra o Ministro da Saúde Pública. 2. Admitir a ação de } \\
\text { descumprimento de sentenças e ditames constitucionais aforada por Santiago } \\
\text { Noé Vasco Morales. 3. Como medida de reparação integral se dispõe: a) que o } \\
\text { representante do Ministério da Saúde Pública, em coordenação com o } \\
\text { representante da Agência de Regulação, Controle e Vigilância Sanitária, dentro }\end{array}$ \\
\hline
\end{tabular}

${ }^{95}$ EQUADOR. Constitución del Equador. Registro Oficial, 20 out. 2008. Art. 35 : “As pessoas adultas maiores, as crianças, os adolescentes, as mulheres grávidas, as pessoas com incapacidade, as pessoas privadas de liberdade e que adoeçam por enfermidades graves ou de alta complexidade receberão atenção prioritária e especializada no âmbito público e privado. A mesma atenção receberão as pessoas em situação de risco, as vítimas de violência doméstica e sexual, maus-tratos na infância, desastres naturais ou antropogênicos. 0 Estado prestará especial proteção às pessoas em condição de dupla vulnerabilidade". Art. 45: "As crianças e adolescentes gozarão dos direitos comuns ao ser humano, além daqueles específicos de sua idade. O Estado reconhecerá e garantirá a vida, incluindo o cuidado e a proteção desde a concepção. As crianças e adolescentes têm direito à integridade física e psíquica; à sua identidade, nome e cidadania; à saúde integral e nutrição; à educação e cultura, ao esporte e recreação; à seguridade social; a ter uma família e desfrutar da convivência familiar e comunitária; à participação social; a ter respeitada sua liberdade e dignidade; a serem consultados nos assuntos que os afetem; a serem educados de maneira prioritariamente em seu idioma e no contexto cultural próprio de seu povo e nacionalidade e a receber informação acerca de seus genitores ou familiares ausentes, salvo se a informação for prejudicial para o seu bem-estar". Disponível em: $<$ http://www.asambleanacional.gov.ec/documentos/constitucion de bolsillo.pdf >. Acesso em: 30.nov.2017. Livre tradução.

${ }^{96}$ EQUADOR. Corte Constitucional del Ecuador. Sentença 074-16-SIS-CC. Relator: Ruth Seni Pinoargote . Registro Oficial $\quad n$ o 800, 15.12.2016. Disponível em: $<$ http://portal.corteconstitucional.gob.ec/Raiz/2016/074-16-SIS-CC/REL SENTENCIA 074-16-SIS-CC.pdf>. Acesso em: 30.nov.2017.

Revista Publicum

Rio de Janeiro, v. 3, n. 2, 2017, p. 286-338

http://www.e-publicacoes.uerj.br/index.php/publicum

DOI: 10.12957/publicum.2017.31883 


\begin{tabular}{|c|c|}
\hline & $\begin{array}{l}\text { do prazo de } 30 \text { dias, analisem e adéquem o Protocolo USFQ-IEMYR- GHRD-001- } \\
201 \text { de Segurança e Eficácia do Tratamento de Sujeitos com Deficiência do } \\
\text { Receptor de Hormônio de Crescimento, tratados com o fator de crescimento } \\
\text { similar à insulina administrado em } 2 \text { doses diárias de } 80 \text { microgramas por quilo } \\
\text { de peso, elaborado pelo Dr. Jaime Aguirre, pela Universidade SanFrancisco de } \\
\text { Quito e pelo Instituto de Endocrinologia IEMYR. O cumprimento desta medida } \\
\text { deverá ser informado pelo Ministro da Saúde Pública e pela Agência de } \\
\text { Regulação, Controle e Vigilância Sanitária a esta Corte em } 5 \text { dias, a partir da } \\
\text { aprovação do protocolo; b) que o representante do Ministério da Saúde Pública, } \\
\text { em coordenação com o representante da Agência de Regulação, Controle e } \\
\text { Vigilância Sanitária, uma vez aprovado o Protocolo USFQ-IEMYR- GHRD-001- } \\
201 \text { de Segurança e Eficácia do Tratamento de Sujeitos com Deficiência do } \\
\text { Receptor de Hormônio de Crescimento, iniciem de forma imediata os trâmites } \\
\text { correspondentes para que o INCRELEX obtenha o respectivo registro sanitário. } \\
\text { O registro sanitário correspondente deverá ser realizado no prazo máximo de } \\
60 \text { dias; c) em razão do efeito intercomunis da presente sentença, que o } \\
\text { Ministro da Saúde Pública, uma vez iniciado o trâmite de registro sanitário do } \\
\text { medicamento INCRELEX, proceda à sua administração às crianças que contem } \\
\text { com o consentimento de seus representantes legais; d) que o representante do } \\
\text { Ministério das Finanças aloque os recursos econômicos correspondentes para } \\
\text { que o Ministério da Saúde Pública proceda à aquisição do medicamento } \\
\text { INCRELEX: e) que dentro de } 60 \text { dias o representante do Ministério da Saúde } \\
\text { Pública formule e implemente um programa de capacitação, em nível nacional, } \\
\text { acerca da Síndrome de Larón, para crianças afetadas e seus pais. f) Como } \\
\text { medida de reabilitação, que o representante do Ministério da Saúde Pública } \\
\text { formule e implemente um programa nacional de atenção psicológica para } \\
\text { crianças afetadas e seus pais" } \text { (tradução livre). }\end{array}$ \\
\hline VOTO VENCIDO & Decisão unânime. \\
\hline $\begin{array}{l}\text { PORQUE O CASO É } \\
\text { PARADIGMÁTICO }\end{array}$ & $\begin{array}{l}\text { O caso é paradigmático não só porque reconhece a primazia do direito à saúde } \\
\text { integral e universal e o princípio da atenção prioritária a crianças e } \\
\text { adolescentes, mas, sobretudo, porque estabelece o dever de os órgãos técnicos } \\
\text { realizarem estudos com vistas ao registro do medicamento pleiteado, o } \\
\text { fornecimento do remédio mesmo na pendência de registro e sua incorporação } \\
\text { pelo sistema de sáude local, assinalando prazo para tanto. O precedente é } \\
\text { citado pelo Observatório Justicia Constitucional, da Universidade Andina Simón } \\
\text { Bolívar, e foi publicado no Boletim de Jurisprudência no } 12 \text { da Corte } \\
\text { Constitucional do Equador }{ }^{98} \text {. }\end{array}$ \\
\hline \multicolumn{2}{|c|}{$\begin{array}{ll}\text { LINK: } \\
\text { CC.pdf }\end{array}$} \\
\hline$\overline{\text { PALAVRAS-CHAVE }}$ & $\begin{array}{l}\text { MEDICAMENTO - CRIANÇAS E ADOLESCENTES - ATENÇÃO PRIORITÁRIA - } \\
\text { SAÚDE - PROTOCOLO DE ALINHAMENTO - FORNECIMENTO DE FÁRMACO SEM } \\
\text { REGISTRO. }\end{array}$ \\
\hline
\end{tabular}

97 EQUADOR. Corte Constitucional del Ecuador. Sentença 074-16-SIS-CC. Relator: Ruth Seni Pinoargote . Registro Oficial no 800, 15.12.2016. Disponível em: <http://portal.corteconstitucional.gob.ec/Raiz/2016/074-16-SIS-CC/REL SENTENCIA 074-16-SIS-CC.pdf>. Acesso em: 30.nov.2017.

98 Observatorio Justicia Constitucional de la Universidad Andina Simón Bolívar. Caso de los niños con Síndrome de Laron. Disponível em:

$<$ https://www.observatoriojusticiaconstitucional.uasb.edu.ec/sentenciasrecomendadas/Lasset publisher/yimyBtNfX2OA/document/id/1537942?inheritRedirect=false >. Acesso em: 30.nov.2017.

Revista Publicum

Rio de Janeiro, v. 3, n. 2, 2017, p. 286-338

http://www.e-publicacoes.uerj.br/index.php/publicum DOI: 10.12957/publicum.2017.31883 


\begin{tabular}{|c|c|}
\hline 5. CASO & $\begin{array}{l}\text { DESENVOLVIMENTO URBANO X DIREITO À MORADIA } \\
\text { (DIREITO À MORADIA, DIREITO AO BEM VIVER E DIREITO DE PROPRIEDADE) }\end{array}$ \\
\hline CLASSE E NúMERo & $\begin{array}{l}\text { Sentença } \mathrm{n} \text { ㅇ 146-14- SEP-CC }{ }^{99} \\
\text { Caso no } 1773-11-\text { EP } \\
\text { Ação Extraordinária de Proteção }\end{array}$ \\
\hline ÓRGÃO JULGADOR & Equador, Corte Constitucional, Pleno \\
\hline RELATOR & Juiz Constitucional Patricio Pazmiño Freire \\
\hline REQUERENTE & Luis Jorge Ramírez Enríquez \\
\hline REQUERIDO & Município do Distrito Metropolitano de Quito \\
\hline DATA DE JULGAMENTO & 1. out.2014 \\
\hline DATA DE PUBLICAÇÃO & $\begin{array}{l}\text { Registro Oficial Suplemento no } 362 \\
\text { 27.out.2014 }\end{array}$ \\
\hline FATOS & $\begin{array}{l}\text { No ano de 2004, a Municipalidade Metropolitana de Quito começou a realizar } \\
\text { trabalhos de alargamento do beco existente do lado leste do imóvel de } \\
\text { propriedade do requerente. As obras em questão acabaram por destruir a casa, } \\
\text { obrigando sua família a abandoná-la às pressas. A família do requerente foi } \\
\text { compelida a providenciar outro local para moradia, convivendo com a falta de } \\
\text { recursos para tanto. Todos estes fatos ocorreram sem que o Município tivesse } \\
\text { declarado o imóvel de utilidade pública ou promovido a correspondente } \\
\text { indenização por danos. }\end{array}$ \\
\hline $\begin{array}{l}\text { FUNDAMENTOS JURÍDICOS } \\
\text { DO PEDIDO }\end{array}$ & $\begin{array}{l}\text { A pretensão inicial acha-se fundada na vulneração ao direito de propriedade, já } \\
\text { que o Município interferiu drasticamente no imóvel do requerente, provocando } \\
\text { a sua total inutilização, sem que qualquer ato expropriatório fosse editado. } \\
\text { Ocorre que tais atos produziram reflexos sobre o direito à moradia adequada e } \\
\text { digna previsto no art. } 66 \text {, numeral } 2 \text {, da Constituição }{ }^{100} \text { e no art. } 11 \text { do Pacto } \\
\text { Internacional de Direitos Econômicos, Sociais e Culturais }{ }^{101} \text {, direito este que } \\
\text { integra o conceito de "buen vivir". Este direito impõe ao Estado a obrigação } \\
\text { positiva de desenvolver políticas públicas e disponibilizar os recursos } \\
\text { econômicos necessários à sua concretização, bem como a obrigação negativa, } \\
\text { de abstenção da prática de condutas que possam reduzir o seu efetivo gozo, } \\
\text { nos termos do art. } 375 \text {, da Constituição }{ }^{102} \text {. }\end{array}$ \\
\hline
\end{tabular}

99 EQUADOR. Corte Constitucional del Ecuador. Sentença 146-14-SEP-CC. Relator: Patricio Pazmiño Freire. Disponível em: <https://www.corteconstitucional.gob.ec/sentencias/relatoria/relatoria/fichas/146-14-SEPCC.pdf>. Acesso em: 30.nov.2017.

100 EQUADOR. Constitución del Equador. Registro Oficial, 20 out. 2008.. Art. 66, numeral 2: "São reconhecidos e garantidos às pessoas: [...] 2. O direito a uma vida digna, que assegure a saúde, alimentação e nutrição, água potável, moradia, saneamento, educação, trabalho, emprego, descanso e ócio, cultura física, vestimenta, seguridade social e outros serviços sociais necessários" (livre tradução). Disponível em: $<$ http://www.asambleanacional.gov.ec/documentos/constitucion de bolsillo.pdf $>$. Acesso em: 30.nov.2017.

101 NAÇÕES UNIDAS. Pacto Internacional dos Direitos Econômicos, Sociais e Culturais. Art. 11: "Os Estados Partes do presente Pacto reconhecem o direito de toda pessoa a um nível de vida adequado para si próprio e sua família, inclusive à alimentação, vestimenta e moradia adequadas, assim como uma melhoria contínua de suas condições de vida. Os Estados Partes tomarão medidas apropriadas para assegurar a consecução desse direito, reconhecendo, nesse sentido, a importância essencial da cooperação internacional fundada no livre consentimento".

Disponível em:<http://www.dge.mec.pt/sites/default/files/ECidadania/educacao para a Defesa a Seguranca e a P az/documentos/pacto internacional sobre direitos economicos sociais culturais.pdf>. Acesso em: 30.nov.2017.

102 EQUADOR. Constitución del Equador. Registro Oficial, 20 out. 2008. Art. 375: "O Estado, em todos os seus níveis de governo, garantirá o direito à moradia, ao habitat e à moradia digna, [...]"(livre tradução). Disponível em: <http://www.asambleanacional.gov.ec/documentos/constitucion de bolsillo.pdf>. Acesso em: 30.nov.2017.

\section{Revista Publicum}

Rio de Janeiro, v. 3, n. 2, 2017, p. 286-338

http://www.e-publicacoes.uerj.br/index.php/publicum

DOI: 10.12957/publicum.2017.31883 


\begin{tabular}{|c|c|}
\hline PEDIDO & $\begin{array}{l}\text { Pretende o requerente seja julgada procedente a ação, a fim de que o } \\
\text { Município Metropolitano de Quito seja condenado a pagar indenizações } \\
\text { correspondentes aos danos materiais e morais gerados pelos atos da } \\
\text { Municipalidade. }\end{array}$ \\
\hline $\begin{array}{l}\text { EMENTA OU TRECHO } \\
\text { DESTACADO }\end{array}$ & $\begin{array}{l}\text { O direito à moradia adequada e digna é um dos direitos que integra os } \\
\text { chamados direitos do "buen vivir", reconhecidos a todas as pessoas cujo } \\
\text { cumprimento compete ao Estado, a quem se atribui dois conjuntos de } \\
\text { obrigações: um conjunto positivo e um conjunto negativo. O positivo } \\
\text { corresponde aos esforços a serem envidados para que esses direitos sejam } \\
\text { acessíveis através da provisão de recursos econômicos, o estabelecimento de } \\
\text { políticas públicas, etc. De outro lado, o conjunto negativo equivale ao dever de } \\
\text { abstenção do Estado de realizar condutas que possam comprometer seu } \\
\text { efetivo gozo. } \\
\text { Neste sentido, o dever do Estado não se esgota na garantia de moradia, } \\
\text { podendo demandar outras prestações, como o estabelecimento de } \\
\text { regulamentos habitacionais, políticas de arrendamento, prestação de serviços } \\
\text { públicos, enfim, a implementação de condições adequadas de habitação, cujo } \\
\text { objetivo seja lograr, na maior medida possível, que as pessoas alcancem o } \\
\text { direito a uma moradia digna, conforme determina a Constituição. }\end{array}$ \\
\hline DECISÃO FINAL & $\begin{array}{l}\text { "1. Declarar a vulneração dos direitos constitucionais à segurança jurídica, à } \\
\text { tutela judicial efetiva, ao devido processo legal, à propriedade, à proibição de } \\
\text { confisco, à moradia adequada e à dignidade humana consagrados na } \\
\text { Constituição da República. } \\
\text { 2. Como medida de reparação integral: } \\
2.1 \text { - Restituir o direito: } \\
\text { a) determinar que o Município do Distrito Metropolitano de Quito materialize } \\
\text { a permuta do bem imóvel em favor dos requerentes, mediante entrega de um } \\
\text { terreno com uma casa que se ajuste ao parâmetros de uma moradia adequada } \\
\text { e digna, além da diferença econômica que a permuta reconhece a favor dos } \\
\text { autores. } \\
2.2 \text { - Reparações imateriais } \\
\text { a) determinar a oferta aos requerentes de assistência psicológica e médica } \\
\text { gratuita, em razão dos abalos sofridos em decorrência dos fatos. } \\
\text { b) determina que a Municipalidade publique em periódico de circulação } \\
\text { nacional extrato do reconhecimento de sua responsabilidade no caso concreto } \\
\text { e um pedido de desculpas. } \\
2.3 \text { - Reparação Material } \\
\text { a) determinar que o Município de Quito pague aos acionantes um valor que } \\
\text { considere o prejuízo econômico que tiveram nos } 10 \text { anos em que foram } \\
\text { obrigados a arrendar locais para morar. } \\
\text { b) determinar que o Município de Quito indenize os equipamentos de cozinha } \\
\text { perdidos com a destruição da casa. } \\
\text { c) determinar que o Município arque com todos os gastos gerados pelos } \\
\text { serviços judiciais contratados até aqui"103 (tradução livre). }\end{array}$ \\
\hline VOTO VENCIDO & Decisão unânime. \\
\hline $\begin{array}{l}\text { PORQUE O CASO É } \\
\text { PARADIGMÁTICO }\end{array}$ & $\begin{array}{l}\text { O caso é paradigmático porquanto estabeleceu o direito à moradia não só como } \\
\text { direito fundamental individual, mas como direito fundamental social, parte } \\
\text { integrante do complexo do buen vivir. Mais do que isso, o precedente aponta a }\end{array}$ \\
\hline
\end{tabular}

103 EQUADOR. Corte Constitucional del Ecuador. Sentença 146-14-SEP-CC. Relator: Patricio Pazmiño Freire. Disponível em: <https://www.corteconstitucional.gob.ec/sentencias/relatoria/relatoria/fichas/146-14-SEPCC.pdf>. Acesso em: 30.nov.2017.

Revista Publicum

Rio de Janeiro, v. 3, n. 2, 2017, p. 286-338

http://www.e-publicacoes.uerj.br/index.php/publicum

DOI: $10.12957 /$ publicum.2017.31883 
existência de duas dimensões de atuação estatal para a garantia do direito à moradia, uma positiva e outra negativa. Tais premissas fundadoras foram empregadas em outros precedentes, como por exemplo na Sentença 344-16SEP-CC ${ }^{104}$. A decisão foi, ainda, publicada em diversos periódicos acadêmicos, dentre eles o Debate Constitucional - Direito Política e Economia, da Fundação Hanns Siedel ${ }^{105}$.

LINK: https://www.corteconstitucional.gob.ec/sentencias/relatoria/relatoria/fichas/146-14-SEP-CC.pdf

\begin{tabular}{l|l} 
PALAVRAS-CHAVE & MORADIA DIGNA - DIREITO SOCIAL - DIREITO AO BEM VIVER.
\end{tabular}

\begin{tabular}{|l|l|}
\hline 6. CASO & $\begin{array}{l}\text { DISCRIMINAÇÃo DE GÊNERO NO TRABALHO } \\
\text { (DIREITO AO TRABALHO) }\end{array}$ \\
\hline CLASSE E NÚMERO & $\begin{array}{l}\text { Sentença 292-16- SEP-CC } 106 \\
\text { Caso no 0734-13- EP } \\
\text { Ação Extraordinária de Proteção }\end{array}$ \\
\hline ÓRGÃO JULGADOR & Equador, Corte Constitucional, Pleno \\
\hline RELATOR & Juíza Constitucional Wendy Molina Andrade \\
\hline REQUERENTE & Yssenia Paola Iza Pilataxi \\
\hline REQUERIDO & Corte Provincial de Justiça de Napo \\
\hline DATA DEJULGAMENTO & 07.set.2016 \\
\hline DATA DE PUBLICAÇÃo & $\begin{array}{l}\text { Registro Oficial Suplemento no 854 } \\
\text { 04.out.2016 }\end{array}$ \\
\hline FATOS & $\begin{array}{l}\text { A requerente desenvolvia a função de bombeira voluntária na cidade de } \\
\text { Archidona e, nada obstante haver ascendido ao cargo de bombeira profissional, } \\
\text { através de ato jurídico próprio, foi dispensada sem qualquer procedimento } \\
\text { administrativo que Ihe oferecesse a possibilidade de conhecer as razões da } \\
\text { dispensa e a elas se contrapor. Sustenta a requerente que a dispensa se deu } \\
\text { por motivo de discriminação de gênero, já que seu chefe frisou, em público, por } \\
\text { diversas vezes, que as funções de bombeiro não deveriam ser executadas por } \\
\text { mulheres, uma vez que não têm condições de se desincumbir das tarefas, } \\
\text { servindo apenas para a cama e a casa. }\end{array}$ \\
\hline $\begin{array}{l}\text { FUNDAMENTOS JURÍDICOS } \\
\text { DO PEDIDO }\end{array}$ & $\begin{array}{l}\text { A pretensão acha-se fundada no direito à igualdade e à não discriminação } \\
\text { assentado no art. 11, numeral } 2 \text { da Constituição da República } \\
\text { implica em reconhecer que nenhuma distinção pessoal ou coletiva, de caráter } \\
\text { temporário ou permanente, poderá ser utilizada como fator de discriminação } \\
\text { caso tenha como resultado menoscabar ou anular o reconhecimento, gozo ou }\end{array}$ \\
\hline
\end{tabular}

104 EQUADOR. Corte Constitucional del Ecuador. Sentença 344-16- SEP-CC. Disponível em: <https://www.corteconstitucional.gob.ec/sentencias/relatoria/relatoria/fichas/344-16-SEP-CC.pdf >. Acesso em: 30.nov.2017.

105 COBO, Maria José Lopez. Utilidad pública y propriedad privada, in Revista Eletrônica Debate Constitucional - Direito, Política e Economia, no 42, dez. 2014/jan. 2015. Disponível em: <https://www.cad.org.ec/wpcontent/uploads/2015/02/debate- constitucional-42.pdf>. Acesso em: 30.nov.2017.

106 EQUADOR. Corte Constitucional del Ecuador. Sentença 292-16-SEP-CC. Relator: Wendy Molina Andrade. Registro Oficial $n$ o 854, 04.10.2016. Disponível em: <https://www.corteconstitucional.gob.ec/sentencias/relatoria/relatoria/fichas/292-16-SEP-CC.pdf>. Acesso em: 30.nov.2017.

107 EQUADOR. Constitución del Equador. Registro Oficial, 20 out. 2008.. Art. 11: “O exercício dos direitos será regido pelos seguintes princípios: [...] 2. Todas as pessoas são iguais e gozam dos mesmos direitos, deveres e oportunidades. Ninguém poderá ser discriminado por razões de etnia, lugar de nascimento, idade, sexo, identidade de gênero, identidade cultural [...]" (livre tradução). Disponível em: $<$ http://www.asambleanacional.gov.ec/documentos/constitucion de bolsillo.pdf $>$. Acesso em: 30.nov.2017. 


\begin{tabular}{|c|c|}
\hline & $\begin{array}{l}\text { exercício de direitos fundamentais. Neste mesmo sentido, o Pacto } \\
\text { Internacional de Direitos Econômicos, Sociais e Culturais, em seu art. 2, } \\
\text { numeral } 2 \text { e art. } 6{ }^{108} \text {, determina o direito de toda pessoa exercer um trabalho } \\
\text { sem discriminações. }\end{array}$ \\
\hline PEDIDo & $\begin{array}{l}\text { Postulou-se que a Corte Constitucional reconhecesse a vulneração dos direitos } \\
\text { constitucionais da requerente e, por consequência, procedesse à sua } \\
\text { reintegração aos quadros do Corpo de Bombeiros de Archidona. }\end{array}$ \\
\hline $\begin{array}{l}\text { EMENTA OU TRECHO } \\
\text { DESTACADO }\end{array}$ & $\begin{array}{l}\text { "O sexo constitui uma categoria suspeita quando utilizado como fator que } \\
\text { autoriza o tratamento diferenciado das pessoas. Toda diferença de tratamento } \\
\text { que se baseie nessa categoria se vê submetida a uma análise estrita, ou seja, a } \\
\text { uma análise que exige um nível muito alto de justificação. Observa-se ao longo } \\
\text { de nossa história mais recente que a discriminação da mulher no aspecto } \\
\text { laboral é recoberta com argumentações sutis, que pretendem justificar de } \\
\text { maneira razoável o seu alijamento de numerosos trabalhos por meio de uma } \\
\text { suposta proteção. Ocorre, todavia, que, com demasiada frequência, se tem } \\
\text { empregado o argumento da debilidade física da mulher para lhe obstaculizar o } \\
\text { acesso a ocupações tidas como perigosas, bem como remunerar-lhe com } \\
\text { salários notadamente inferiores aos dos homens ou, inclusive, para impedir } \\
\text { que trabalhe, em função da maternidade. Ora, se a Constituição previu o direito } \\
\text { à igualdade formal, à igualdade material e à não discriminação, resulta difícil } \\
\text { pensar que uma atividade, seja laboral, política, acadêmica ou de outro tipo, } \\
\text { possa estar condicionada pelo sexo, pela idade ou pela nacionalidade [...]. O } \\
\text { princípio da igualdade de tratamento e de oportunidades em razão do sexo } \\
\text { deve impregnar todos os âmbitos da sociedade, sendo importante que se } \\
\text { aplique no âmbito laboral público e privado. É evidente a clara situação de } \\
\text { desvantagem de direito em que se encontram as mulheres no âmbito laboral, } \\
\text { assentada precisamente em aspectos ligados ao sexo biológico ou aos seus } \\
\text { papéis sociais, do que decorre uma menor incorporação ao mercado de } \\
\text { trabalho e, uma vez incorporadas, piores condições laborais, maiores } \\
\text { dificuldades para a formação e promoção profissional, dentre outras muitas } \\
\text { situações de desigualdade material" } \text {. (tradução livre) }\end{array}$ \\
\hline DECISÃO FINAL & $\begin{array}{l}\text { "1. Declarar a violação ao direito de tutela judicial, à igualdade e à não } \\
\text { discriminação. 2. Como medida de reparação integral, se dispõe: a) Deixar sem } \\
\text { efeito as decisões proferidas pela Corte Provincial de Naipo. b) Que o Governo } \\
\text { de Arquidona promova a imediata reintegração da requerente ao posto de } \\
\text { bombeira que ocupava quando da exclusão da corporação, disponibilizando a } \\
\text { ela a assistência médica e psicológica de que necessitar para recuperar-se dos } \\
\text { males sofridos em decorrência da exclusão. c) Que o Governo de Arquidona } \\
\text { ponha em dia as verbas de seguridade social devidas desde a exclusão da } \\
\text { requerente. d) Que o Governo de Arquidona indenize a requerente por danos }\end{array}$ \\
\hline
\end{tabular}

108 OIT. Convenção no 169 da OIT. Art. 2ํ, numeral 2: "Os Estados Partes do presente Pacto comprometem-se a garantir os direitos nele enunciados e que não exercerão discriminação alguma por motivo de raça, cor, sexo, religião, opinião política ou de outra natureza, origem nacional ou social, situação econômica, nascimento ou qualquer outra situação". Art. 60: "Os Estados Partes do presente Pacto reconhecem o direito ao trabalho, que compreende o direito de toda pessoa de ter a possibilidade de ganhar a vida mediante um trabalho livremente escolhido ou aceito, e tomarão medidas apropriadas para salvaguardar esse direito". Disponível em: <http://www.ilo.org/brasilia/convencoes/WCMS 236247/lang--pt/index.htm>. Acesso em: 30.nov.2017.

109 EQUADOR. Corte Constitucional del Ecuador. Sentença 292-16-SEP-CC. Relator: Wendy Molina Andrade. Registro Oficial $n$ o 854, 04.10.2016. Disponível em: <https://www.corteconstitucional.gob.ec/sentencias/relatoria/relatoria/fichas/292-16-SEP-CC.pdf >. Acesso em: 30.nov.2017. 


\begin{tabular}{|c|c|}
\hline & $\begin{array}{l}\text { morais, utilizando os requisitos estabelecidos na sentença 004-13-SAN-CC } \\
\text { como parâmetro para o cálculo do montante. e) Que o Conselho de } \\
\text { Administração do Corpo de Bombeiros promova desculpas públicas à } \\
\text { requerente mediante ato simbólico, no qual reconheça a violação aos direitos } \\
\text { fundamentais a uma vida livre de violência, à igualdade e à não discriminação. } \\
\text { O ato de desagravo deverá destacar a valentia da requerente, que acorreu à } \\
\text { Justiça para denunciar os feitos de violência de que estava sendo vítima. Em } \\
\text { honra à requerente, todas as funcionárias do Corpo de Bombeiros Municipal } \\
\text { de Archidona deverão ser incentivadas a denunciar os atos de violência contra } \\
\text { mulheres, impondo-se à instituição o dever de assegurar-lhes respaldo para } \\
\text { tanto e o desprezo a qualquer forma de maus-tratos à população feminina. f) } \\
\text { Que o Município de Archidona e o Corpo de Bombeiros Municipal } \\
\text { confeccionem um protocolo de trabalho com visão de gênero e iniciem uma } \\
\text { campanha de rechaço social às agressões deste tipo que preveja medids de } \\
\text { proteção às vítimas de violência de gênero. g) Ao reconhecer que a sociedade } \\
\text { equatoriana traz arraigados consigo estereótipos orientados para a suposta } \\
\text { inferioridade das mulheres no âmbito laboral e consciente de que isto não deve } \\
\text { continuar, tem-se que é evidente que a mudança dos padrões culturais é uma } \\
\text { tarefa difícil e o primeiro passo deve ser dado pelas instituições públicas e } \\
\text { privadas, bem como pelos funcionários judiciais. Frise-se que estes últimos são } \\
\text { encarregados de gerar confiança nas vítimas acerca da resposta estatal ante a } \\
\text { violência de gênero. Portanto, como garantia da não repetição de fatos como } \\
\text { os que aqui foram apontados, devem os funcionários judiciais ser instados a } \\
\text { aplicar a lei com enfoque de gênero. Para tanto, deve-se comunicar ao } \\
\text { Conselho da Magistratura" }{ }^{110} \text {. (tradução livre) }\end{array}$ \\
\hline VOTO VENCIDO & Decisão unânime. \\
\hline $\begin{array}{l}\text { PORQUE O CASO É } \\
\text { PARADIGMÁTICO }\end{array}$ & $\begin{array}{l}\text { O caso é paradigmático porque põe luzes sobre a questão da discriminação de } \\
\text { gênero no âmbito do trabalho, determinando-se a adoção, pelas instituições } \\
\text { envolvidas, de protocolo laboral com enfoque na questão, além de indicar que } \\
\text { as autoridades judiciais encarregadas deste tipo de causa não deixem de } \\
\text { realizar interpretação que contemple o fator de gênero e suas repercussões no } \\
\text { direito social ao trabalho. A sentença foi selecionada para figurar no frontpage } \\
\text { do sítio da Corte Constitucional do Equador. }\end{array}$ \\
\hline \multicolumn{2}{|c|}{ LINK: https://www.corteconstitucional.gob.ec/sentencias/relatoria/relatoria/fichas/292-16-SEP-CC.pdf } \\
\hline PALAVRAS-CHAVE & RO - TRABALHO - DISCRIMINAÇAO. \\
\hline
\end{tabular}

\begin{tabular}{|l|l|}
\hline 7. CASO & $\begin{array}{l}\text { ESTABILIDADE DE GESTANTE NO EMPREGO } \\
\text { (DIREITO AO TRABALHO E PROTEÇÃO À MATERNIDADE) }\end{array}$ \\
\hline CLASSE E NÚMERO & $\begin{array}{l}\text { Sentença no 309-16- SEP-CC } \\
\text { Caso no 111 } \\
\text { Ação Extraordinária de Proteção }\end{array}$ \\
\hline ÓRGÃo JULGADOR & Equador, Corte Constitucional, Pleno \\
\hline
\end{tabular}

110 EQUADOR. Corte Constitucional del Ecuador. Sentença 292-16-SEP-CC. Relator: Wendy Molina Andrade. Registro Oficial no 854, 04.10.2016. Disponível em: $<$ https://www.corteconstitucional.gob.ec/sentencias/relatoria/relatoria/fichas/292-16-SEP-CC.pdf >. Acesso em: 30.nov.2017.

111 EQUADOR. Corte Constitucional del Ecuador. Sentença 309-16-SEP-CC. Relator: Alfredo Ruiz Guzmán. Registro Oficial $n$ o 866, 20.10.2016. Disponível em: <https://www.corteconstitucional.gob.ec/sentencias/relatoria/relatoria/fichas/309-16-SEP-CC.pdf >. Acesso em: 30.nov.2017. 


\begin{tabular}{|c|c|}
\hline RELATOR & Juiz Constitucional Alfredo Ruiz Guzmán \\
\hline REQUERENTE & Evelyn Tamara Naranjo Tacuri \\
\hline REQUERIDO & Banco de Desenvolvimento do Equador \\
\hline DATA DE JULGAMENTO & 21.set.2016 \\
\hline DATA DE PUBLICAÇÃO & $\begin{array}{l}\text { Registro Oficial Suplemento no } 866 \\
\text { 20.out. } 2016\end{array}$ \\
\hline FATOS & $\begin{array}{l}\text { A requerente foi contratada por tempo determinado pelo Banco de } \\
\text { Desenvolvimento do Equador e trabalhou por três anos e meio, até chegar ao } \\
\text { fim o pacto laboral. Em virtude do término do contrato, a requerente foi } \\
\text { dispensada de suas funções, mesmo estando grávida, sem direito a qualquer } \\
\text { indenização, atenção médica ou licença maternidade. Frisa a autora que seu } \\
\text { trabalho consistia na única fonte de renda da família. }\end{array}$ \\
\hline $\begin{array}{l}\text { FUNDAMENTOS JURÍDICOS } \\
\text { DO PEDIDO }\end{array}$ & $\begin{array}{l}\text { A pretensão inicial funda-se: (i) na violação do direito ao trabalho; (ii) na } \\
\text { proibição de discriminação contra mulheres grávidas; (iii) na atenção prioritária } \\
\text { à maternidade; (iv) no direito a uma vida digna; e (v) no direito à igualdade, } \\
\text { consagrados nos arts. } 33,43,331,35 \text { e } 66 \text {, numeral } 2 \text {, letra b, da Constituição } \\
\text { do Equador }{ }^{112} \text {. Destaca-se que o princípio da igualdade representa um dos } \\
\text { pilares de toda a sociedade bem organizada e de todo o Estado Constitucional. } \\
\text { Este princípio impõe ao Estado o dever de tratar os indivíduos de tal modo que } \\
\text { os deveres e as vantagens sociais sejam distribuídas equitativamente entre } \\
\text { eles. No caso das mulheres grávidas no contexto laboral, apesar de terem várias } \\
\text { semelhanças com os demais trabalhadores e trabalhadoras, a condição de } \\
\text { grávidas as coloca em situação de desvantagem, de tal modo que devem } \\
\text { merecer especial proteção. Bem por isso, a Constituição assegurou a elas } \\
\text { atenção prioritária e especializada no âmbito público e privado. Pois bem, no } \\
\text { caso concreto, a decisão de não renovar o contrato temporário de trabalho de } \\
\text { uma mulher grávida ou em lactância agrava a vulnerabilidade em que já se } \\
\text { encontra, visto que seu sustento depende do trabalho que realiza. Isto não quer } \\
\text { dizer que devam ser abolidas as normas gerais que regem os contratos de } \\
\text { trabalho em regime temporário, mas sim que tais normas devem ser } \\
\text { flexibilizadas, a fim de contemplarem direitos fundamentais sociais } \\
\text { reconhecidos pela Constituição equatoriana, a exemplo do que se decidiu na }\end{array}$ \\
\hline
\end{tabular}

112 EQUADOR. Constitución del Equador. Registro Oficial, 20 out. 2008. Art. 33: “O trabalho é um direito e um dever social e um direito econômico, fonte de realização pessoal e base da economia. O Estado garantirá aos trabalhadores o pleno respeito à sua dignidade e uma vida decorosa, remuneração e retribuições justas e o desempenho de um trabalho saudável e livremente escolhido e aceito". Art. 43: "O Estado garantirá às mulheres grávidas e em período de lactância os direitos a: 1 . Não ser discriminada por sua gravidez nos âmbitos educativo, social e laboral. 2. A gratuidade dos serviços de saúde materna. 3. A proteção prioritária e o cuidado de sua saúde integral e de sua vida durante a gravidez, parto e pós-parto. 4. Dispor das facilidades necessárias para sua recuperação depois da gravidez e durante a amamentação". Art. 331: "O Estado garantirá às mulheres igualdade no acesso ao emprego, à formação e promoção laboral e profissional, à remuneração equitativa e à iniciativa de trabalho autônomo. Serão adotadas todas as medidas necessárias para eliminar as desigualdades". Art. 35: "As pessoas adultas maiores, as crianças, os adolescentes, as mulheres grávidas, as pessoas com incapacidade, as pessoas privadas de liberdade e que adoeçam por enfermidades graves ou de alta complexidade receberão atenção prioritária e especializada no âmbito público e privado. A mesma atenção receberão as pessoas em situação de risco, as vítimas de violência doméstica e sexual, maus-tratos na infância, desastres naturais ou antropogênicos. O Estado prestará especial proteção às pessoas em condição de dupla vulnerabilidade". Art. 66: "São reconhecidos e garantidos às pessoas: [...] 2. O direito a uma vida digna, que assegure a saúde, alimentação e nutrição, água potável, moradia, saneamento, educação, trabalho, descanso, vestuário, seguridade social e outros serviços sociais necessários". Disponível <http://www.asambleanacional.gov.ec/documentos/constitucion de bolsillo.pdf>. Acesso em: 30.nov.2017. Livre tradução.

Revista Publicum

Rio de Janeiro, v. 3, n. 2, 2017, p. 286-338

http://www.e-publicacoes.uerj.br/index.php/publicum DOI: 10.12957/publicum.2017.31883 


\begin{tabular}{|c|c|c|}
\hline & & $\begin{array}{l}\text { Sentença no } 258-15-S E P-C^{113} \text {, em relação aos portadores de necessidades } \\
\text { especiais. }\end{array}$ \\
\hline Pedido & & $\begin{array}{l}\text { Pretende a requerente seja reconhecida a violação aos seus direitos } \\
\text { constitucionais ao trabalho, à atenção especial em virtude da maternidade e à } \\
\text { não discriminação laboral de gênero, a fim de que seja determinada a } \\
\text { reparação integral do dano que lhe foi causado pela dispensa ilegal. }\end{array}$ \\
\hline $\begin{array}{l}\text { EMENTA OU } \\
\text { DESTACADO }\end{array}$ & TRECHO & 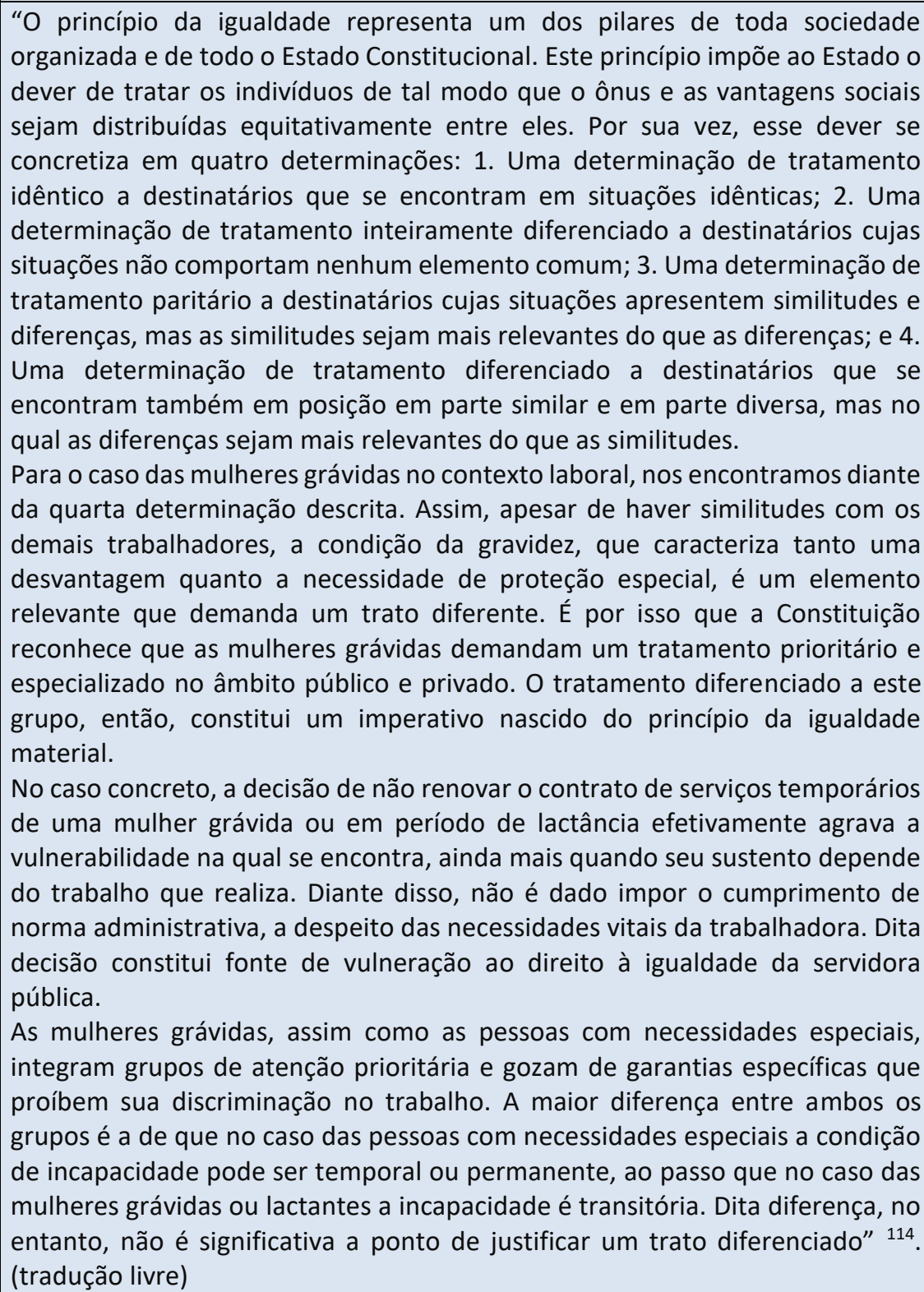 \\
\hline
\end{tabular}

113 EQUADOR. Corte Constitucional del Ecuador. Sentença 258-15-SEP-CC. Relator: Patrício Herrera. Registro Oficial no 605, 12.10.2015. Disponível <https://www.corteconstitucional.gob.ec/sentencias/relatoria/relatoria/fichas/258-15-SEP-CC.pdf >. Acesso em: 30.nov.2017.

114 EQUADOR. Corte Constitucional del Ecuador. Sentença 309-16-SEP-CC. Relator: Alfredo Ruiz Guzmán. Registro Oficial $n$ o 866, 20.10.2016. Disponível em: <https://www.corteconstitucional.gob.ec/sentencias/relatoria/relatoria/fichas/309-16-SEP-CC.pdf >. Acesso em: 30.nov.2017. 


\begin{tabular}{|c|c|}
\hline DECISÃO FINAL & $\begin{array}{l}\text { "1. Declarar a violação aos direitos à igualdade e à não discriminação das } \\
\text { mulheres no contexto do trabalho. } 2 \text {. Determinar ao Banco de } \\
\text { Desenvolvimento do Equador a publicação da sentença em seu espaço na web. } \\
\text { 3. Determinar ao Banco que peça desculpas à vítima e à sua família, a serem } \\
\text { publicadas em jornal de circulação nacional. 4. Determinar ao Banco o } \\
\text { pagamento dos valores que a autora deixou de receber desde sua ilegal } \\
\text { dispensa. 5. Declarar a constitucionalidade condicionada do art. } 58 \text { da Lei } \\
\text { Orgânica do Serviço Público, a fim de que sejam renovados os contratos } \\
\text { temporários das mulheres grávidas ou estado de lactância até o final do ano } \\
\text { fiscal em que termina este último período". (tradução livre) }\end{array}$ \\
\hline VOTO VENCIDO & Decisão unânime. \\
\hline $\begin{array}{l}\text { PORQUE O CASO É } \\
\text { PARADIGMÁTICO }\end{array}$ & $\begin{array}{l}\text { O caso é paradigmático porquanto a Corte Constitucional do Equador analisou } \\
\text { a questão posta sob o enfoque do princípio da igualdade e estabeleceu a } \\
\text { renovação dos contratos temporários de trabalho de mulheres grávidas ou em } \\
\text { período de lactância. A sentença foi selecionada pela Corte Constitucional } \\
\text { equatoriana para figurar na frontpage de seu website, além de ter sido objeto } \\
\text { de artigos acadêmicos publicados na revista eletrônica da Universidade de } \\
\text { Utmachala }{ }^{115} \text {. }\end{array}$ \\
\hline \multicolumn{2}{|c|}{ LINK: https://www.corteconstitucional.gob.ec/sentencias/relatoria/relatoria/fichas/309-16-SEP-CC.pdf } \\
\hline PALAVRAS-CHAVE & $\begin{array}{l}\text { ESTABILIDADE - EMPREGO - GRAVIDEZ - } \\
\text { IGUALDADE MATERIAL - PROTEÇÃO À MATERNIDADE. }\end{array}$ \\
\hline
\end{tabular}

\begin{tabular}{|l|l|}
\hline 8. CASO & $\begin{array}{l}\text { MORADIA DIGNA } \\
\text { (DIREITO À MORADIA) }\end{array}$ \\
\hline CLASSE E NÚMERO & $\begin{array}{l}\text { Sentença no 344-16-SEP-CC116 } \\
\text { Caso no 1180-10-EP } \\
\text { Ação de Proteção Extraordinária }\end{array}$ \\
\hline ÓRGÃO JULGADOR & Equador, Corte Constitucional, Pleno \\
\hline RELATOR & Juíza Constitucional Roxana Silva Chicaiza \\
\hline REQUERENTE & María Mercedes Zumba Morocho \\
\hline REQUERIDO & Ministro do Desenvolvimento Urbano e de Moradia \\
\hline DATA DE JULGAMENTO & 26.out.2016 \\
\hline DATA DE PUBLICAÇÃo & $\begin{array}{l}\text { Suplemento de Registro Oficial no 889 } \\
\text { 24.nov.2016 }\end{array}$ \\
\hline FATOS & $\begin{array}{l}\text { A requerente pleiteou administrativamente o recebimento de "bônus } \\
\text { moradia", verba destinada a fazer frente aos reparos indispensáveis à } \\
\text { conservação da residência onde vivia com seus netos menores, todos eles filhos } \\
\text { de sua falecida filha. Em que pese ter o Ministério do Desenvolvimento Urbano } \\
\text { e de Moradia - MIDUVI considerado que as condições de sua residência eram } \\
\text { deploráveis e insalubres, bem como pertencer a requerente a grupo de atenção }\end{array}$ \\
\hline
\end{tabular}

115 LISSETE, Velesaca Jenniffer Rivera. Estudio dogmático ujurídico del derecho al despido ineficaz en la legislacion laboral del Ecuador, in Repositório Digital da Universidade Utmachala. Disponível em: <http://www.repositorio.utmachala.edu.ec/bitstream/48000/10381/1/RIVERA\%20VELESACA\%20JENNIFE\% 20LISSETTE.pdf>. Acesso em: 30.11.2017; ORDOÑEZ. Nicolay Bolivar Alvarado. Despido ineficaz de la mujer trabajadora en estado de gestacion, in Repositório Digital da Universidade Utmachala. Disponível em: <http://www.repositorio.utmachala.edu.ec/bitstream/48000/10338/1/ORDOÑEZ\%20ALVARADO\%20NICOL AY\%20BOLIVAR.pdf >. Acesso em: 30.nov.2017.

116 EQUADOR. Corte Constitucional del Ecuador. Sentença 344-16-SEP-CC. Relator: Roxana Silva Chicaiza. Registro Oficial no 504, 24.11.2016. Disponível em: <https://www.corteconstitucional.gob.ec/sentencias/relatoria/relatoria/fichas/344-16-SEP-CC.pdf >. Acesso em: 30.nov.2017. 


\begin{tabular}{|c|c|}
\hline & $\begin{array}{l}\text { prioritária, já que possuía baixa renda, era idosa ( } 80 \text { anos) e criava os filhos } \\
\text { menores órfãos de sua filha, o pedido foi indeferido. Alegou-se, então, que era } \\
\text { preciso a nomeação de tutor ou curador legal às crianças para que o processo } \\
\text { de legalização do terreno que pertencia à mãe delas pudesse ter curso, sem o } \\
\text { que seria inviável o recebimento da verba. }\end{array}$ \\
\hline $\begin{array}{l}\text { FUNDAMENTOS JURÍDICOS } \\
\text { DO PEDIDO }\end{array}$ & $\begin{array}{l}\text { A pretensão inicial tem fundamento no disposto no art. } 66 \text {, numeral } 4 \text {, da } \\
\text { Constituição do Equador }{ }^{117} \text {, que estabelece o princípio da igualdade material. } \\
\text { Assim, todos os indivíduos têm direito a um mínimo de proteção estatal que } \\
\text { lhes possibilite a sobrevivência digna. Neste contexto, estariam contemplados } \\
\text { direitos fundamentais de integrantes de grupos de atenção prioritária, como os } \\
\text { idosos, as crianças e os adolescentes em situação de vulnerabilidade social } \\
\text { (arts. } 35 \text { e } 37 \text { da Constituição da República }{ }^{118} \text { e Sentença no } 064-15-\text { SEP-CC }{ }^{119} \text { ). } \\
\text { De outro lado, o art. } 66 \text {, numeral } 2 \text { da Constituição Equatoriana }{ }^{120} \text { consagra o } \\
\text { dever do Estado de garantir os direitos decorrentes do buen vivir, dentre eles o } \\
\text { direito à moradia digna. Nesta perspectiva, os empecilhos de ordem } \\
\text { administrativa não podem constituir obstáculos a impedir a fruição deste } \\
\text { direito, cabendo ao Estado a articulação de soluções céleres e eficazes. }\end{array}$ \\
\hline PEDIDO & $\begin{array}{l}\text { Requer a declaração de existência de ações e omissões que violaram direitos } \\
\text { constitucionais a uma vida digna e à saúde da requerente, ordenando ao } \\
\text { MIDUVI que lhe outorgue o direito a uma moradia adequada. }\end{array}$ \\
\hline $\begin{array}{l}\text { EMENTA OU TRECHO } \\
\text { DESTACADO }\end{array}$ & $\begin{array}{l}\text { "Com relação ao direito postulado, a Corte Constitucional se pronunciou por } \\
\text { meio da Sentença no } 117-13-S E P-C C \text {, indicando que o direito à igualdade } \\
\text { constitui o pilar sobre o qual se assenta a teoria dos direitos constitucionais, } \\
\text { fazendo parte do grupo de princípios reconhecidos por todos os Estados como } \\
\text { a proteção mínima a ser estendida às pessoas, pressuposto de sobrevivência } \\
\text { da raça humana [...]. Das disposições normativas anotadas se colige que a } \\
\text { Constituição do Equador instituiu de maneira categórica a obrigação de } \\
\text { prestação por parte do Estado que reforce a proteção aos grupos de atenção } \\
\text { prioritária e favoreçam uma real inclusão social e econômica, que propendam } \\
\text { a eliminação de todas as formas de discriminação. Nesse sentido, o Estado tem }\end{array}$ \\
\hline
\end{tabular}

117 EQUADOR. Constitución del Equador. Registro Oficial, 20 out. 2008. Art. 66: "São reconhecidos e garantidos: [...] 4. Direito à igualdade formal, igualdade material e não discriminação". Disponível em: $<$ http://www.asambleanacional.gov.ec/documentos/constitucion de bolsillo.pdf>. Acesso em: 30.nov.2017.

118 EQUADOR. Constitución del Equador. Registro Oficial, 20 out. 2008. Art. 35: "As pessoas adultas maiores, as crianças, os adolescentes, as mulheres grávidas, as pessoas com incapacidade, as pessoas privadas de liberdade e que adoeçam por enfermidades graves ou de alta complexidade receberão atenção prioritária e especializada no âmbito público e privado. A mesma atenção receberão as pessoas em situação de risco, as vítimas de violência doméstica e sexual, maus-tratos na infância, desastres naturais ou antropogênicos. 0 Estado prestará especial proteção às pessoas em condição de dupla vulnerabilidade". Art. 37: "O Estado garantirá às pessoas adultas mais velhas os seguintes direitos: [...] 7. $\mathrm{O}$ acesso a uma moradia que assegure uma vida digna, com respeito a sua opinião e consentimento". Disponível em: <http://www.asambleanacional.gov.ec/documentos/constitucion de bolsillo.pdf $>$. Acesso em: 30.nov.2017.

119 EQUADOR. Corte Constitucional del Ecuador. Sentença 064-15-SEP-CC. Relator: Tatiana Ordeñana Sierra. Registro Oficial no 889, 20.05.2015. Disponível em: $<$ https://www.corteconstitucional.gob.ec/sentencias/relatoria/relatoria/fichas/064-15-SEP-CC.pdf>. Acesso em: 30.nov.2017.

${ }^{120}$ EQUADOR. Constitución del Equador. Registro Oficial, 20 out. 2008. Art. 66: "São reconhecidos e garantidos às pessoas: [...] 2. O direito a uma vida digna, que assegure a saúde, alimentação e nutrição, água potável, moradia, saneamento, educação, trabalho, descanso, vestuário seguridade social e outros serviços sociais necessários" (livre tradução). Disponível em: http://www.asambleanacional.gov.ec/documentos/constitucion de bolsillo.pdf>. Acesso em: 30.nov.2017.

Revista Publicum

Rio de Janeiro, v. 3, n. 2, 2017, p. 286-338

http://www.e-publicacoes.uerj.br/index.php/publicum

DOI: 10.12957/publicum.2017.31883 


\begin{tabular}{|c|c|}
\hline & $\begin{array}{l}\text { a obrigação de proteger este grupo populacional e criar políticas públicas } \\
\text { dirigidas à superação da pobreza, adotar medidas afirmativas que favoreçam } \\
\text { sua integração à sociedade e o acesso aos direitos sociais que Ihes permitam } \\
\text { levar uma vida digna" }{ }^{121} \text {. (tradução livre) }\end{array}$ \\
\hline DECISÃO FINAL & $\begin{array}{l}\text { "1. Declarar a violação dos direitos à motivação, à igualdade material e ao } \\
\text { direito à moradia adequada e digna. [...] 3.2. Manter a decisão de } 14 \text { de junho } \\
\text { de } 2010 \text {, proferida pelo Juízo de Cañar - Tambo, que julgou procedente a ação } \\
\text { de proteção. Nada obstante, dado o falecimento da legitimada ativa para a } \\
\text { causa e a desintegração de sua família, a reparação de danos será resolvida nos } \\
\text { termos desta sentença, que terá cumprimento obrigatório. 3.3. Determinar que } \\
\text { o Ministério do Desenvolvimento Urbano e Moradia promova ato simbólico de } \\
\text { desculpas públicas à família da requerente na praça principal da comunidade } \\
\text { de Caguanapamba, cantón El Tambo, de la província de Cañar, no dia em que } \\
\text { se realiza a feira semanal, no qual deverá reconhecer a sua responsabilidade no } \\
\text { caso concreto e pedir desculpas pela violação de seus direitos constitucionais. } \\
\text { [...] 3.4. Determinar que o pessoal do MIDUVI receba do Ministério capacitação } \\
\text { em tema de direitos humanos, com ênfase na garantia de grupos de atenção } \\
\text { prioritária. [...] 4. [...] Com o objetivo de tutelar os direitos dos grupos de } \\
\text { atenção prioritária, declara a constitucionalidade condicionada do art. 7o do } \\
\text { Regulamento para Operação do Sistema de Incentivos para a Moradia [...], para } \\
\text { o qual a Corte Constitucional emite a seguinte sentença interpretativa: Quando } \\
\text { o postulante a um incentivo habitacional for uma pessoa que pertença a } \\
\text { qualquer das categorias de atenção prioritária estabelecidas no art. 35 da } \\
\text { Constituição Equatoriana, cuja renda não ultrapasse um salário-mínimo, a } \\
\text { postulação deverá ser aceita e atendida imediatamente, mesmo que não } \\
\text { possua título de propriedade. [...]" } 122 \text {. (tradução livre) }\end{array}$ \\
\hline VOTO VENCIDO & Decisão unânime. \\
\hline $\begin{array}{l}\text { PORQUE O CASO É } \\
\text { PARADIGMÁTICO }\end{array}$ & $\begin{array}{l}\text { O caso é paradigmático porque identificou os grupos que merecem atenção } \\
\text { prioritária aos quais deve ser garantido direito à moradia digna e, portanto, } \\
\text { incentivo habitacional estatal, independentemente de outros requisitos } \\
\text { formais. }\end{array}$ \\
\hline \multicolumn{2}{|c|}{ LINK: https://www.corteconstitucional.gob.ec/sentencias/relatoria/relatoria/fichas/344-16-SEP-CC.pdf } \\
\hline PALAVRAS-CHAVE & $\begin{array}{l}\text { MORADIA DIGNA - IGUALDADE MATERIAL - ATENÇÃO PRIORITÁRIA - } \\
\text { VULNERABILIDADE SOCIAL. }\end{array}$ \\
\hline
\end{tabular}

\begin{tabular}{|l|l|}
\hline 9. CASO & $\begin{array}{l}\text { TRATAMENTO DO VíRUS HIV } \\
\text { (DIREITO À SAÚDE) }\end{array}$ \\
\hline CLASSE E NúMERO & $\begin{array}{l}\text { Sentença } \mathrm{n} \text { - 364-16- SEP-CC } \\
\text { Caso 1470-14- EP }\end{array}$ \\
\hline
\end{tabular}

121 EQUADOR. Corte Constitucional del Ecuador. Sentença 344-16-SEP-CC. Relator: Roxana Silva Chicaiza. Registro Oficial no 504, 24.11.2016. Disponível em: <https://www.corteconstitucional.gob.ec/sentencias/relatoria/relatoria/fichas/344-16-SEP-CC.pdf >. Acesso em: 30.nov.2017.

122 EQUADOR. Corte Constitucional del Ecuador. Sentença 344-16-SEP-CC. Relator: Roxana Silva Chicaiza. Registro Oficial no 504, 24.11.2016. Disponível em: <https://www.corteconstitucional.gob.ec/sentencias/relatoria/relatoria/fichas/344-16-SEP-CC.pdf>. Acesso em: 30.nov. 2017.

123 EQUADOR. Corte Constitucional del Ecuador. Sentença 364-16-SEP-CC. Relator: Tatiana Ordeñana Sierra. Registro Oficial no 800, 15.12.2016. Disponível em: <https://www.corteconstitucional.gob.ec/sentencias/relatoria/relatoria/fichas/364-16-SEP-CC.pdf >. Acesso em: 30.nov.2017. 


\begin{tabular}{|c|c|}
\hline & Ação Extraordinária de Proteção \\
\hline ÓRGÃO JULGADOR & Equador, Corte Constitucional, Pleno \\
\hline RELATOR & Juíza Constitucional Tatiana Ordeñana Sierra \\
\hline REQUERENTE & NN \\
\hline REQUERIDO & $\begin{array}{l}\text { Instituto Ecuatoriano de Seguridad Social (IESS); Hospital Carlos Andrade Marín } \\
\text { (HCAM). }\end{array}$ \\
\hline DATA DEJULGAMENTO & 15.nov.2016 \\
\hline DATA DE PUBLICAÇÃO & $\begin{array}{l}\text { Registro Oficial Suplemento Edição Especial no } 800 \\
\text { 15.dez. } 2016\end{array}$ \\
\hline FAtOS & $\begin{array}{l}\text { NN buscou amparo na Corte Constitucional, depois de ter frustrada a pretensão } \\
\text { de obter medicamento essencial ao tratamento do vírus HIV, do qual é } \\
\text { portador, fundado no fato de o fármaco não estar disponível nos estoques do } \\
\text { hospital. }\end{array}$ \\
\hline $\begin{array}{l}\text { FUNDAMENTOS JURÍDICOS } \\
\text { DO PEDIDO }\end{array}$ & $\begin{array}{l}\text { A pretensão inicial se funda na violação ao direito à tutela judicial efetiva, } \\
\text { imparcial e célere, prevista no art. } 75 \text { da Constituição Federal }{ }^{124} \text {, no art. } 25.1 \text { da } \\
\text { Convenção Americana dos Direitos Humanos }{ }^{125} \text { e nos precedentes } 142-14-S E \text { - } \\
\text { CC }^{126} \text { e } 006-13-S E P-C C^{127} \text {, porquanto teria o Juízo de piso deixado de dar } \\
\text { consequência às medidas cautelares pleiteadas pelo requerente. A pretensão } \\
\text { se funda, também, na violação ao direito constitucional à saúde, insculpido no } \\
\text { art. } 32 \text { da Carta Magna Equatoriana, ofendido que teria sido pela não entrega } \\
\text { do medicamento que fazia parte do tratamento do requerente, pela simples } \\
\text { falta de disponibilidade na farmácia pública do Hospital. }\end{array}$ \\
\hline PEDIDO & $\begin{array}{l}\text { Requereu fosse declarada a violação de seus direitos ao devido processo legal; } \\
\text { à tutela judicial efetiva, imparcial e célere e à recepção de atenção médica } \\
\text { prioritária por pertencer a grupo vulnerável. }\end{array}$ \\
\hline $\begin{array}{l}\text { EMENTA OU TRECHO } \\
\text { DESTACADO }\end{array}$ & $\begin{array}{l}\text { "[...] O direito à saúde constitui um direito de conteúdo complexo, tanto assim } \\
\text { que não pode ser considerado apenas como a ausência de enfermidade num } \\
\text { determinado momento, mas implica também na obrigação do Estado de atuar } \\
\text { de forma preventiva por meio de serviços e prestações que permitam o } \\
\text { desenvolvimento adequado das capacidades físicas e psíquicas dos sujeitos } \\
\text { protegidos, assim como o dever do Estado de fornecer atenção médica, } \\
\text { tratamento de enfermidades e administração de medicamentos às pessoas }\end{array}$ \\
\hline
\end{tabular}

${ }^{124}$ EQUADOR. Constitución del Equador. Registro Oficial, 20 out. 2008. Art. 75: "Toda pessoa tem direito de acesso gratuito à justiça e à tutela efetiva, imparcial e rápida de seus direitos e interesses, com sujeição aos princípios da imediatidade e celeridade. O descumprimento das resoluções judiciais será sancionado pela lei" (livre tradução). Disponível em: <http://www.asambleanacional.gov.ec/documentos/constitucion de bolsillo.pdf>. Acesso em: 30.nov.2017.

125 OEA. Convenção Americana sobre Direitos Humanos. Art. 25, numeral 1: "Toda pessoa tem direito a um recurso simples e rápido ou a qualquer outro recurso efetivo, perante os juízes ou tribunais competentes, que a proteja contra atos que violem seus direitos fundamentais reconhecidos pela constituição, pela lei ou pela presente Convenção, mesmo quando tal violação seja cometida por pessoas que estejam atuando no exercício de suas funções oficiais". Disponível em: <http://www.cidh.oas.org/basicos/portugues/c.convencao americana.htm> . Acesso em: 30.11.2017 ${ }_{126}$ EQUADOR. Corte Constitucional del Ecuador. Sentença 142-14-SEP-CC. Relator: Fabian Marcelo Jaramillo Villa. Registro Oficial $\quad n$ o 374, 13.11.2014. Disponível em: <https://www.corteconstitucional.gob.ec/sentencias/relatoria/relatoria/fichas/142-14-SEP-CC.pdf >. Acesso em: 30.nov.2017.

127 EQUADOR. Corte Constitucional del Ecuador. Sentença 006-13-SEP-CC. Relator: Wendy Molina Andrade. Registro Oficial $n$ o 933, 15.04.2013. Disponível em: <https://www.corteconstitucional.gob.ec/sentencias/relatoria/relatoria/fichas/006-13-SEP-CC.pdf>. Acesso em: 30.nov.2017. 


\begin{tabular}{|c|c|}
\hline & $\begin{array}{l}\text { afetadas em sua saúde. De igual forma, o direito à saúde impõe a obrigação ao } \\
\text { Estado de fortalecer os serviços de saúde pública e de assegurar as condições } \\
\text { para que os cidadãos possam acessar de maneira permanente a serviços de } \\
\text { saúde de qualidade, sem nenhuma exclusão. [...]"128. (tradução livre) }\end{array}$ \\
\hline DECISÃO FINAL & $\begin{array}{l}\text { "1. Declarar a vulneração dos direitos constitucionais à tutela judicial efetiva, } \\
\text { imparcial e célere e à saúde consagrados nos arts. } 75 \text { e } 32 \text { da Constituição da } \\
\text { República129. 2. Determinar as seguintes medidas de garantia para que as } \\
\text { violações não se repitam: a) Que o Conselho de Magistratura, através de seu } \\
\text { representante legal, efetue uma ampla difusão do conteúdo desta sentença } \\
\text { entre juízes e juízas com competência para julgar causas semelhantes; b) Que } \\
\text { o Instituto de Seguridade Social oficie às casas de saúde que integram o regime } \\
\text { de seguridade social, esclarecendo que não poderão se abster de prescrever e } \\
\text { administrar aos portadores de HIV medicação integrante de seu tratamento, } \\
\text { por questões meramente administrativas; c) Que as instituições da rede pública } \\
\text { de saúde deverão provisionar seus estoques de medicamento de combate ao } \\
\text { HIV, a fim de que suas farmácias possam disponibilizar o medicamento. } 3 \text {. } \\
\text { Determinar as seguintes medidas de satisfação: a) Que o Instituto de } \\
\text { Seguridade Social ofereça desculpas públicas à vítima. As desculpas deverão ser } \\
\text { publicadas em diário de circulação nacional e em local visível de seu portal na } \\
\text { web pelo prazo de três meses. } 4 \text {. Determinar aos juízes e juízas que quando } \\
\text { apreciarem uma ação que tenha por fundamento um padrão fático similar ao } \\
\text { presente caso, onde se tenha demonstrado a falta de prescrição ou } \\
\text { administração de medicamento antiretroviral a uma pessoa portadora de HIV } \\
\text { num centro público de saúde em razão de causas que não sejam estritamente } \\
\text { médicas, deverão declarar a violação do direito constitucional à saúde"130. }\end{array}$ \\
\hline VOTO VENCIDO & Decisão unânime. \\
\hline $\begin{array}{l}\text { PORQUE O CASO É } \\
\text { PARADIGMÁTICO }\end{array}$ & $\begin{array}{l}\text { A decisão determinou o Estado está obrigado a manter os estoques de } \\
\text { medicamento antiretroviral para o HIV e que o não fornecimento por ausência } \\
\text { de disponibilidade constitui violação do direito à saúde. A sentença foi alvo de } \\
\text { estudos acadêmicos como o que se acha abrigado no Repositório Digital da } \\
\text { Universidade de Utmachala }{ }^{131} \text {. }\end{array}$ \\
\hline \multicolumn{2}{|c|}{ LINK: https://www.corteconstitucional.gob.ec/sentencias/relatoria/relatoria/fichas/364-16-SEP-CC.pdf } \\
\hline PALAVRAS-CHAVE & SAÚDE - FORNECIMENTO DE FÁRMACO - HIV. \\
\hline
\end{tabular}

128 EQUADOR. Corte Constitucional del Ecuador. Sentença 364-16-SEP-CC. Relator: Tatiana Ordeñana Sierra. Registro Oficial no 800, 15.12.2016. Disponível em: < https://www.corteconstitucional.gob.ec/sentencias/relatoria/relatoria/fichas/364-16-SEP-CC.pdf>. Acesso em: 30.nov.2017.

129 EQUADOR. Constitución del Equador. Registro Oficial, 20 out. 2008. Art. 32: "A saúde é um direito garantido pelo Estado, cuja realização se vincula ao exercício de outros direitos, dentre eles o direito à água, à alimentação, à educação, à cultura física, ao trabalho, à seguridade social, aos ambientes sãos e outros que sustentam o bem viver" (livre tradução). Disponível em: $<$ http://www.asambleanacional.gov.ec/documentos/constitucion de bolsillo.pdf $>$. Acesso em: 30.nov.2017.

130 EQUADOR. Corte Constitucional del Ecuador. Sentença 364-16-SEP-CC. Relator: Tatiana Ordeñana Sierra. Registro Oficial no 800, 15.12.2016. Disponível em: <https://www.corteconstitucional.gob.ec/sentencias/relatoria/relatoria/fichas/364-16-SEP-CC.pdf>. Acesso em: 30.nov.2017.

131 GALARZA, Jhon Marcio Orellana. Analisis juridico de la sentencia no 364-16-SEP-CC emitida por la corte constitucional y su influencia en el sistema jurisdicional ecuatoriano, in Repositório Digital de la UTMACH. Disponível em: <http://repositorio.utmachala.edu.ec/handle/48000/10306>. Acesso em: 30.nov.2017. 